\title{
EDUCAÇÃO AMBIENTAL EM UNIDADES DE CONSERVAÇÃO: UM ESTUDO DE CASO NA ÁREA DE PROTEÇÃO AMBIENTAL DE SOUSAS E JOAQUIM EGÍDIO
}

\section{LILIAN PATRÍCIA VENDRAMETTO}

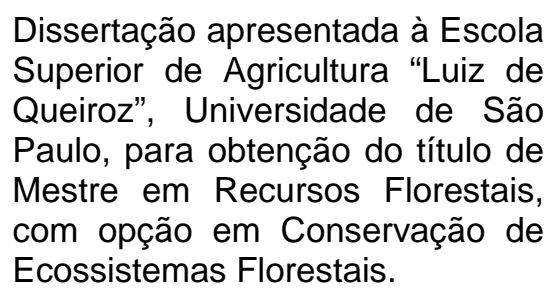

P I R A C I C A B A

Estado de São Paulo - Brasil

Fevereiro - 2004 


\title{
EDUCAÇÃO AMBIENTAL EM UNIDADES DE CONSERVAÇÃO: UM ESTUDO DE CASO NA ÁREA DE PROTEÇÃO AMBIENTAL DE SOUSAS E JOAQUIM EGÍDIO
}

\author{
LILIAN PATRÍCIA VENDRAMETTO \\ Engenheira Agrônoma
}

Orientador: Prof. Dr. ÁLVARO FERNANDO DE ALMEIDA

Dissertação apresentada à Escola
Superior de Agricultura "Luiz de Queiroz",
Universidade de São Paulo, para
obtenção do título de Mestre em
Recursos Florestais, com opção em
Conservação de Ecossistemas
Florestais.

PIRACICABA

Estado de São Paulo - Brasil

Fevereiro - 2004 


\section{Dados Internacionais de Catalogação na Publicação (CIP) DIVISÃO DE BIBLIOTECA E DOCUMENTAÇÃO - ESALQ/USP}

Vendrametto, Lilian Patrícia

Educação ambiental em unidades de conservação: um estudo de caso na área de proteção ambiental de Sousas e Joaquim Egídio / Lilian Patrícia Vendrametto. - -

Piracicaba, 2004.

$108 \mathrm{p}$.

Dissertação (mestrado) - - Escola Superior de Agricultura Luiz de Queiroz, 2004.

Bibliografia.

1. Degradação ambiental (Recuperado) 2. Ecossistema floresta 3. Educação ambiental Monitoramento ambiental 5. Política ambiental 6. Proteção ambiental 7. Saneamento ambiental I. Título

CDD 333.707

"Permitida a cópia total ou parcial deste documento, desde que citada a fonte - O autor" 


\section{AGRADECIMENTOS}

Ao meu pai Oduvaldo, à minha mãe Luiza e as minhas irmãs Lígia e Leila que sempre com muito amor, carinho e dedicação foram os grandes incentivadores de minha aprendizagem;

Ao Marcos Sorrentino pelas valiosas contribuições, pela amizade e intensa dedicação, além do constante compromisso com o meu aprendizado;

À Família von Bulow Ulson, especialmente a Susie, pela amizade, apoio, confiança, e paciência nos momentos difíceis;

Às amigas e companheiras Ana Paula, Henriqueta e Vivian, pelos momentos de grandes reflexões ambientais, pelas valiosas trocas e incentivos, pela amizade, ajudas, compartilhando as alegrias e dividindo as tristezas. Ao inesquecível apoio de Vivian na difícil fase final da dissertação, muito obrigada. As divertidas acolhidas de Milena e Ana Paula.

Ao Professor Álvaro pela oportunidade e orientação;

À Escola "Ângela Cury Zackia" pelas contribuições, acesso a informações e acolhimento;

Aos companheiros de trabalho João Mendes, Tereza Sanches, Tâmide Lelli, Glauco Paiva, Domingos e Adriano Souza. E toda a querida equipe do Parque-Escola: Fátima I, Priscila, Dienai, Sabrina, Val, Hat, Lamarca, Macarrão, André, Sirlei, Flavia, Ricardo, Abner, Sergio, Wagner e Fabinho pela compreensão nos momentos de ausência, lamúrias e divagações. 


\section{SUMÁRIO}

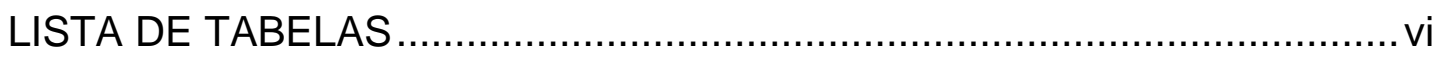

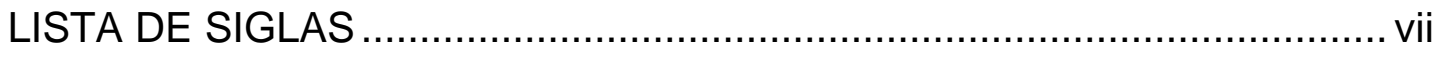

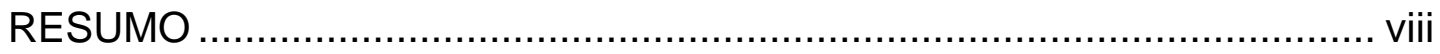

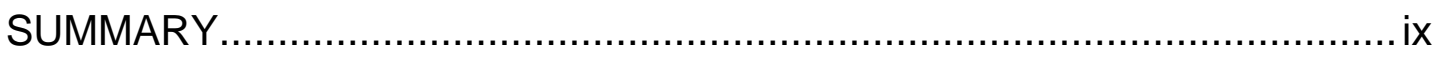

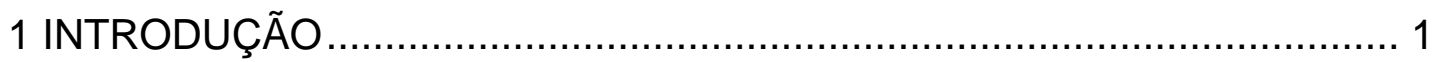

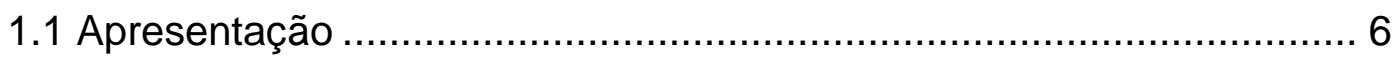

2 CARACTERIZAÇÃO DA ÁREA DE PROTEÇÃO AMBIENTAL DE

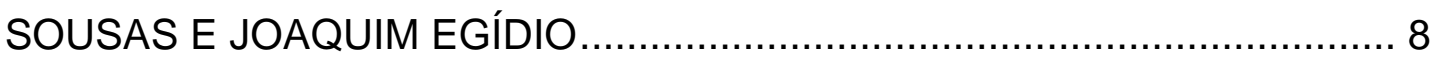

2.1 Conceituação de Áreas de Proteção Ambiental .................................... 8

2.2 Regulamentação da Apa de Sousas e Joaquim Egídio....................... 10

2.3 Caracterização da Apa de Sousas e Joaquim Egídio ........................ 11

2.4 Degradação Ambiental na Apa de Sousas e Joaquim Egídio ............ 15

2.5 Mobilização Comunitária/Ambientalista nos Distritos ......................... 21

2.6 O Centro de Educação Ambiental de Joaquim Egídio: "Estação

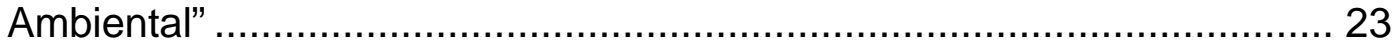

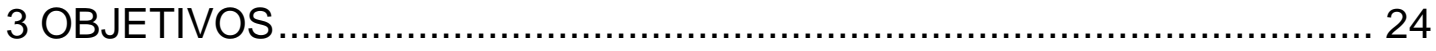

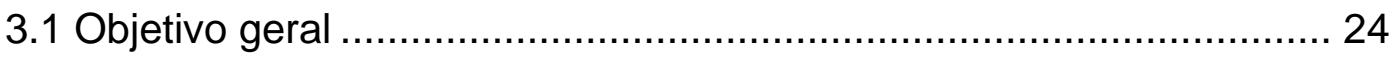

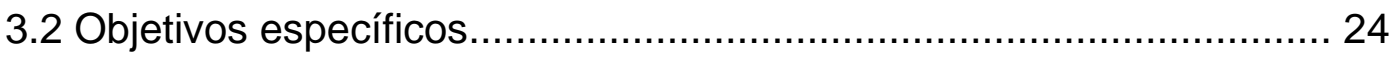

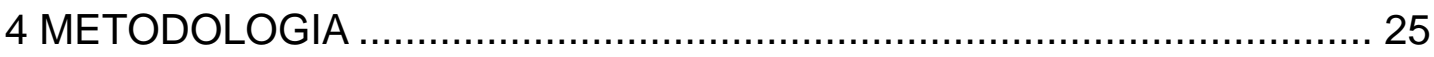

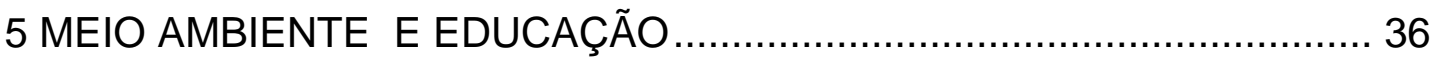

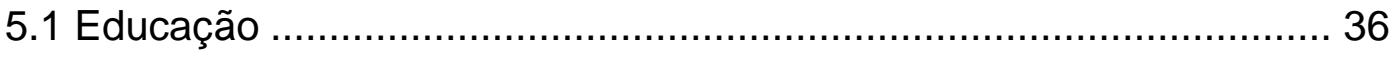

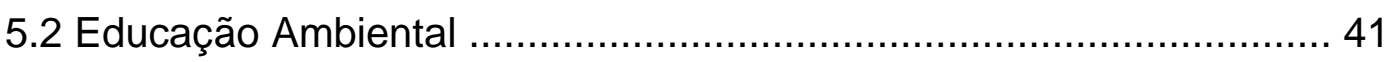

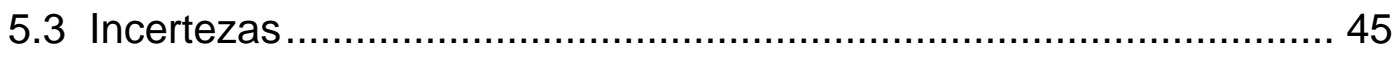

$5.4 \mathrm{O}$ sentimento de pertencimento …............................................... 47

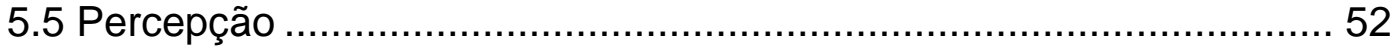

5.6 Cidadania, coletividade e participação. ............................................ 54

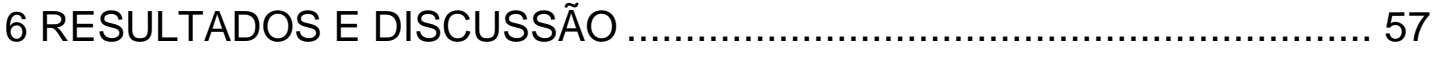

6.1 Violência e sobrevivência ............................................................ 57 
6.2 Volta ao passado, Fuga para o futuro e Sonhos de um mundo melhor.

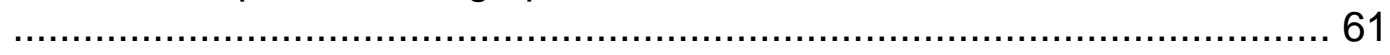

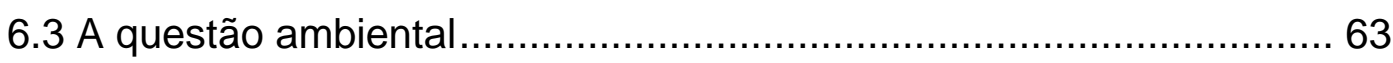

6.3.1 Entendimento sobre meio ambiente ........................................ 64

6.3.2 Caracterização de problema ambiental .................................... 67

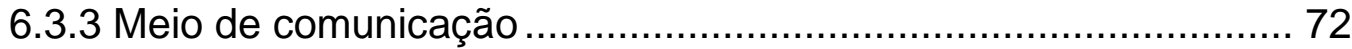

6.3.4 Falta de conhecimento ambiental ........................................ 75

6.3.5 Participação nos assuntos ambientais..................................... 77

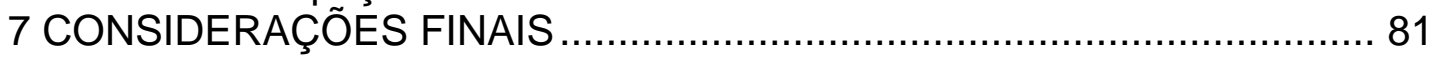

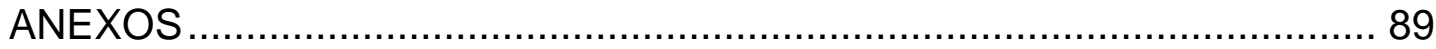

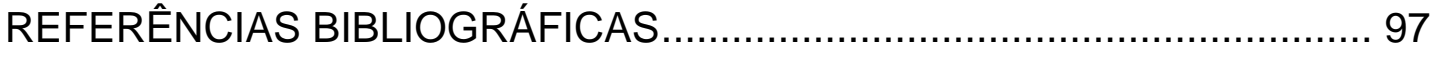




\section{LISTA DE TABELAS}

Tabela 1. Questão 1: Para você, o que é meio ambiente? .......................... 64

Tabela 2. Questão 14: O que faz parte do meio ambiente ? ........................ 66

Tabela 3. Questão 2: No seu entender, o que são problemas ambientais? 68

Tabela 4. Questão 3: Dê 5 exemplos de problemas ambientais.................. 69

Tabela 5. Questão 12: O que você considera como problema ambiental?.. 70

Tabela 6. Questão 4 A: No seu entender, existem problemas ambientais em

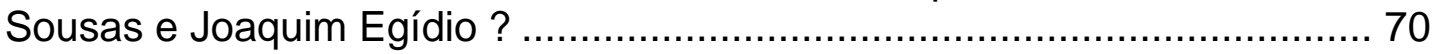

Tabela 7. Questão 4 B: Quais ? .......................................................... 70

Tabela 8. Questão 5 A: Você se incomoda com esses problemas ? ............ 71

Tabela 9. Questão 5 B: Por que?.......................................................... 71

Tabela 10. Questão 13: Você costuma ter informações a respeito do meio

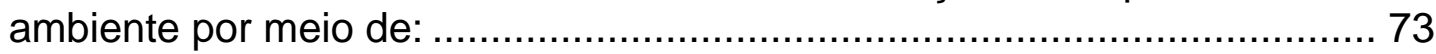

Tabela 11. Questão 10: Você sabe o que é Apa ? ................................... 76

Tabela 12. Questão 11: O que significa Apa e qual sua importância?......... 76

Tabela 13. Questão 6: Quem são os responsáveis pelo surgimento dos

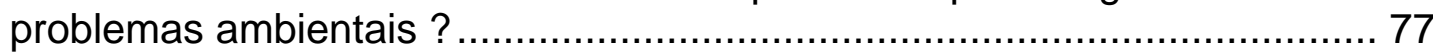

Tabela 14. Questão 7: Quem são os responsáveis pela solução desses problemas?

Tabela 15. Questão 8: Como você acha que as pessoas podem colaborar para melhorar e/ou conservar o ambiente em que vivem ?

Tabela 16. Questão 9: O que você tem feito para melhorar e/ou conservar o ambiente em que vive? 


\title{
LISTA DE SIGLAS
}

\author{
Apa Área de Proteção Ambiental \\ APA/SJE Área de Proteção Ambiental de Sousas e Joaquim Egídio \\ EA Educação Ambiental \\ EMBRAPA Empresa Brasileira de Pesquisa Agropecuária \\ IPT Instituto de Pesquisa Tecnológica \\ SEPLAMA Secretaria Municipal de Planejamento e Meio Ambiente
}




\title{
EDUCAÇÃO AMBIENTAL EM UNIDADES DE CONSERVAÇÃO: UM ESTUDO DE CASO NA ÁREA DE PROTEÇÃO AMBIENTAL DE SOUSAS E JOAQUIM EGÍDIO
}

\author{
Autora: LILIAN PATRÍCIA VENDRAMETTO \\ Orientador: Prof. Dr. ÁLVARO FERNANDO DE ALMEIDA
}

\section{RESUMO}

Esta pesquisa visa contribuir para a produção de conhecimentos que subsidiem atividades de educação ambiental através da descrição de um estudo de caso realizado junto aos alunos moradores da Área de Proteção Ambiental de Sousas e Joaquim Egídio, localizada em Campinas - São Paulo. O grupo formado por alunos da $7^{a}$ série da Escola Municipal de Ensino Fundamental "Ângela Cury Zackia" constituiu o público-alvo da pesquisa. Seu foco está na análise da compreensão da questão ambiental para os alunos moradores. Foi utilizado como referencial metodológico o estudo de caso, a pesquisa qualitativa e pesquisa-ação, com auxílio de instrumentos como: entrevistas semi-estruturadas, questionários, análise documental e realização de oficinas. Busca-se refletir sobre o significado de meio ambiente e natureza e caracterizar do grupo frente ao envolvimento, participação e compromisso nos problemas relacionados ao meio ambiente. 


\title{
ENVIRONMENTAL EDUCATION IN CONSERVATION UNITS - THE CASE OF AREA OF ENVIRONMENTAL PROTECTION OF SOUSAS AND JOAQUIM EGÍDIO
}

\author{
Author: LILIAN PATRÍCIA VENDRAMETTO \\ Adviser: Prof. Dr. ÁLVARO FERNANDO DE ALMEIDA
}

\section{SUMMARY}

This research aims at to contribute for the production of knowledge that subsidize activities of ambient education through the description of a study of case carried through together to the living pupils of the Area of Environment Protection of Sousas and Joaquin Egídio, located in Campinas - S.P. The group formed for pupils of $7^{\text {a }}$ series of the Municipal School of Basic Education "Ângela Cury Zackia" it constituted the public-target of the research. Its focus is in the analysis of the understanding of the ambient question for the living pupils. It was used as referencial metodológico the case study, the qualitative research and research-action, with aid of instruments as: half-structuralized interviews, questionnaires, documentary analysis and accomplishment of workshops. One searchs to reflect on the meaning of environment and nature for this group of students. The characterization of the group front to the envolvement, participation and commitment in the problems related to the environment. 


\section{INTRODUÇÃO}

"Nós somos seres bombardeados pelo espetáculo do mundo. Abrimos a janela pela manhã e um outdoor já nos dá um tapa na cara: "Compre esta cueca!" (...). Lá vêm também os anúncios de remédio: "Tome não-sei-o-quê contra a azia!" As placas na rua, a propaganda na traseira do ônibus circular, os painéis dentro do metrô, na calçada: "Compre celular mais barato!" Alguém aborda você numa esquina e entrega um papelzinho: "Restaurante por quilo!" Na Internet, piscam ofertas: "Sexo tântrico!", "Sorteio de camisolas!"

Os caminhos que percorremos nos açoitam. Castigam-nos com vergastadas nos olhos e nos ouvidos, torturam-nos com os imperativos do consumo. Pobres de nós. As mesmas vozes e as mesmas imagens que nos excitam nos frustram. Não conseguimos obedecer a tantas ordens, atender a tantos apelos. Somos seres bombardeados, sim, e somos seres desobedientes. Perambulamos por entre assédios impositivos e nos vemos impotentes, em dois sentidos. Não temos posses para aceitá-los, nem poder para silenciá-los. A máquina de vender em que se transformou o mundo, esse espetáculo-camelô, existe para humilhar cada um de nós.

Penso então nas crianças, nos alunos do Ensino Fundamental. Não deve ser fácil crescer na babel dos vendilhões. Elas ligam a televisão para ver um desenho animado e lá está a apresentadora loira dando pulinhos e comandos esganiçados: "Compre a sandalinha!" As crianças, mais do que nós, são chicoteadas pela histeria consumista. Pior: têm de se formar sujeitos no meio dessa histeria, num ambiente em que ser sujeito significa ser capaz de consumir. Também elas lidam com excitação e frustração o tempo todo. Em doses muito mais elevadas do que as enfrentadas pelas gerações anteriores.

Definitivamente, não deve ser fácil. Deve ser sufocante. O caos gerado pelas incontáveis mensagens publicitárias não é apenas um caos: é uma narrativa compacta. À primeira vista, o que nos bombardeia é a bagunça de muitos anúncios diferentes, de autores diferentes e emissores diferentes, para públicos diferentes.(...). Preste mais atenção e você verá, por baixo do caos, uma narrativa em que o herói não é um personagem, mas um verbo: ter. (...) é o protagonista, o vetor da felicidade. As pessoas são coadjuvantes.

Por favor, não me peça o antídoto para esse inferno. Eu não o conheço. Mas, se a sua sala de aula conseguir ser um refúgio para as crianças que, lá fora, são metralhadas sem trégua pelo imperativo do ter, talvez já ajude. Não é uma solução, eu sei. Talvez seja somente um instante de paz, um lugar onde nossos filhos não padeçam na impotência. Talvez seja um alívio. A sala de aula, ao seguir outra lógica que não a do consumo, pode virar um bálsamo, um espaço indispensável para que a criança se estruture com outros valores. Pode ser uma ilusão, mas não é uma ilusão animadora?"

Eugenio Bucci 
A questão ambiental neste início de milênio vem ganhando grande espaço frente às preocupações mundiais em relação ao futuro e a sobrevivência da humanidade. Intensa reflexão a respeito do ambiente no qual a sociedade atual está inserida vêm ocorrendo. Dentre elas destacam-se: o subdesenvolvimento econômico e social africano sub-saariano, as mudanças climáticas globais causadas pelas emissões gasosas, as poluições, a escassez da água e do solo, o desmatamento nos países em desenvolvimento e finalmente, as discussões acerca da dúvida sobre para onde queremos caminhar e como vamos trilhar esse caminho se continuarmos com o atual padrão de vida, pensando necessariamente no consumo dos recursos naturais e não-naturais existentes no planeta.

Segundo artigo publicado no jornal Folha de São Paulo, Angelo (2000) revela que se fossem mantidos os atuais padrões de consumo da sociedade, seriam necessários mais "meia Terra" para garantir esse padrão insustentável. Ou seja, "a pressão ecológica exercida nos recursos supera em 42,5 \% a capacidade de renovação da biosfera". O mesmo autor, em 2002, comenta o relatório da ONU para o meio ambiente no qual o planeta vive uma "encruzilhada ecológica" e as previsões são assustadoras, $40 \%$ da humanidade já sofre com a escassez de água, porcentagem que tende aumentar em mais de $10 \%$ e agravar a seriedade do problema até 2050.

Paralelamente ao desenvolvimento econômico e tecnológico, temos os impactos causados pelo impressionante crescimento demográfico, pela urbanização sem planejamento, pela industrialização onde os índices de violência, exclusão social e desemprego crescem a níveis alarmantes principalmente concentrados nos países chamados de "sub-desenvolvidos e em desenvolvimento". $\mathrm{Na}$ área social e de saúde percebe-se que os avanços tecnológicos ainda não foram convertidos em melhoria da qualidade de vida para grande parcela da população mundial.

A Área de Proteção Ambiental (APA) da região de Joaquim Egídio e Sousas situa-se no quadrante Nordeste do município de Campinas, com área aproximada de $223 \mathrm{~km} 2$, abrangendo todo o território do interflúvio dos rios Atibaia e Jaguari no município de Campinas e possuindo altitudes que variam de 
550 metros na planície do Atibaia a 1078 metros na Serra das Cabras, sendo a porção mais elevada no município. Representa $27,39 \%$ da área do município de Campinas, limitando-se com os municípios de Jaguariúna, Pedreira, Morungaba e Valinhos. É constituída em sua maior parte por área rural e caracteriza-se por apresentar baixa densidade de urbanização. Compreende integralmente os distritos de Sousas e Joaquim Egídio, que juntos correspondem a pouco mais de 2/3 da área total da APA (Mattosinho, 2000).

Campinas é uma metrópole urbanizada em crescimento que ocorreu e ocorre de forma desordenada e apresenta problemas de ordem sócio-econômica como aumento da população urbana, expansão descontrolada da franja periférica, ocupações irregulares, intensificação do trânsito, falta de áreas verdes, poluição, entre outros.

Campinas situa-se na área de transição entre a região do Planalto Atlântico e Depressão Periférica, fato esse que determina as mudanças morfológicas - as elevações vão cedendo lugar para as áreas mais planas e os solos vão ficando menos férteis, dependendo da natureza do substrato rochoso. A região da APA apresenta diferentes características sobre o uso e ocupação do solo, menores índices de urbanização, baixa concentração populacional, grande quantidade de fazendas e áreas verdes e, conseqüentemente, maior proporção de área rural. Isso contribui para a grande especulação imobiliária e o alto valor da terra. Essa área apresenta alta rede de drenagem e inúmeras nascentes, por ser um divisor de águas. O rio Atibaia é responsável por $80 \%$ do fornecimento de água para abastecimento de Campinas. Os terrenos são frágeis e muito susceptíveis à erosão, em função da composição das rochas e do solo, bem como das características naturais do relevo (Mattosinho, 2000).

Devido a esse conjunto de características, as práticas agrícolas e demais formas de ocupação do solo requerem cuidados. Atualmente, $2,8 \%$ da área do município de Campinas tem vegetação nativa; mais de $60 \%$ desse pequeno índice concentra-se na região da APA e remonta da época das sesmarias, as quais foram posteriormente desmembradas e originaram as grandes fazendas de cana e café. A arquitetura colonial das suas sedes e edificações complementares 
constitui rico patrimônio histórico, estético e cultural. Atualmente a região é alvo, da especulação imobiliária, correndo risco de ser rapidamente desfigurada. Portanto, há uma grande necessidade em investir em programas de educação e conscientização ambiental, em mudanças de atitudes e comportamentos, uma maior participação da comunidade e de medidas efetivas de proteção e preservação do ambiente (Mattosinho, 2000).

Nesse contexto que este projeto de educação ambiental pretende trabalhar, como instrumento estratégico de promoção da consciência ambiental e integração da sociedade com a natureza, visando uma forma de vida sustentável, atrelando conhecimento com participação, ou seja, envolvimento, compromisso e entendimento de que a responsabilidade pelo futuro do planeta e suas reais possibilidades de reverter o processo de degradação e desequilíbrio são, certamente de cada cidadão, nas suas ações individuais e coletivas.

Krasilchik (1986) faz uma brilhante reflexão sobre o papel da educação ambiental: funcionar como elemento integrador, para que a comunidade tome consciência do fenômeno do desenvolvimento e de suas implicações ambientais. "Para tanto, deverá servir não só para transmitir conhecimentos, mas também para desenvolver habilidades e atitudes que permitam ao homem atuar efetivamente no processo de manutenção do equilíbrio ambiental de modo a garantir uma qualidade de vida condizente com suas necessidades e aspirações. (...) Para que a Educação Ambiental atinja plenamente seus objetivos, alguns aspectos devem ser considerados: propiciar aos alunos uma base sólida de conhecimentos (...) Porém, apenas o conhecimento é insuficiente. A base da Educação Ambiental reside no envolvimento e participação."

Neste mesmo sentido, Vianna (1996) complementa: "O processo educativo deve transformar-se em instrumento a serviço da elaboração, discussão e concretização de uma nova ordem social. (...) Dessa forma prepara o homem para "reivindicar o direito de opinar, discutir e criticar" e alterar essa mesma ordem social, seu acesso a cultura e a história de seu tempo (...) Tal processo educativo seria então dialético, global, contínuo e consciente". 
Há necessidade de uma educação que propicie e estimule o aluno a interagir ativamente no processo decisório de todo o seu "meio ambiente", entendido como a sua casa, sua escola, sua rua, seu bairro, sua cidade, seu estado, seu país, sua nação. Serres (1991), concorda quando comenta: “(..) nossa relação com o mundo mudou. Antes era local-local agora é local-global (...)".

A percepção ambiental é "uma resultante não só do impacto objetivo das condições reais (do ambiente) sobre os indivíduos, mas também da maneira como sua interveniência social e valores culturais agem na captação dos mesmos impactos".Jacobi, (1994).

Segundo Moscovici, citado por Sawaia (1994) no seu abrangente trabalho sobre representações sociais, na relação do homem com a natureza, o ser humano busca "a realização das suas necessidades", dentro de um "conjunto de relações sociais e de uma cultura específica, o indivíduo cria suas próprias representações das coisas e fixa o aspecto fenomenal da realidade".

Portanto, este trabalho pretende disponibilizar espaços de reflexão sobre a banalização do consumismo, o distanciamento e aprisionamento das metrópoles, uma possibilidade de diálogo com a natureza na tentativa de repensar a relação desequilibrada do ser humano com o meio ambiente, nas suas atitudes individuais e coletivas e questionamento das obviedades cotidianas. Nas palavras de Milton Santos (2000), "Na era da ecologia triunfante, é o homem quem fabrica a natureza, ou the atribui valor e sentido, por meio de suas ações (...)".

Algumas inquietações pessoais levaram a esta pesquisa: o que moradores de um local, dotado de beleza cênica e rico em elementos naturais, entendem pelas questões ambientais? O que os sensibiliza, os toca, os aflige em relação a problemática ambiental?

A sua realização em uma escola deve-se ao fato de acreditar-se ser ela um espaço especial, onde programas de educação ambiental possam ser discutidos, refletivos, experimentados e implantados. 


\subsection{Apresentação}

A idéia inicial partiu do desejo em se tentar compreender a importância da questão ambiental no contexto de vida dos moradores de áreas sob proteção especial graças a seus atributos ambientais peculiares. Uma tentativa de entender se dentro do cotidiano desses indivíduos o meio ambiente e suas relações ocupavam algum espaço, ou não, se eram deixados a um segundo plano. A idéia inicial em se trabalhar com o tema percepção ambiental e representação social acabou aos poucos sendo uma dimensão pouco explorada, pois a pesquisa foi se redesenhando e outros caminhos foram sendo percorridos.

A formação acadêmica em Engenharia Agronômica, voltada para área das ciências exatas, distante das áreas de psicologia e sociologia gerou inicialmente certas dificuldades mas delineou questionamentos filosóficos anteriormente pouco discutidos, o que tornou o trabalho ainda mais interessante.

Pensou-se em trabalhar em escolas por se acreditar ser ela um importante espaço de trabalho da Educação Ambiental. Acreditava-se inicialmente que moradores de uma área considerada especial (mais de $60 \%$ do resta de vegetação nativa da cidade se concentra em áreas da APA) eram sensibilizados pos essas características peculiares, que contemplavam, admiravam, reconheciam o valor ambiental e cultural do local, sentiam-se "especiais" por viverem próximos de um local dotado de atributos tão encantadores.

Algumas perguntas emergiram durante o decorrer da pesquisa:

a) Qual o entendimento que tem sobre meio ambiente? Incluem-se no meio ambiente? Há espaço para as criações/edificações humanas? Ou somente aos aspectos naturais? E a natureza? Qual a concepção sobre ela?

b) Quais são seus desejos e sonhos? Quais inquietações os afligem? Há alguma relação entre essas e a questão ambiental? As preocupações se concretizam em ações? 
c) Quem são os responsáveis pelas ações ocorridas no meio ambiente? O poder público? Todos nós?

d) Quais os vínculos estabelecidos entre o espaço e o território?

A pesquisa está dividida em três partes, I, II e III, constituídas de sete capítulos.

A Parte I é composta pelos quatro primeiros capítulos. No capítulo I Introdução - está descrita toda a trajetória da pesquisa, sua idéia inicial, a hipótese que dava contorno a mesma e a forma como foi sendo redesenhada e reestruturada. No capítulo II - Caracterização da APA de Sousas e Joaquim Egídio - tem como objetivo situar o leitor ao local onde foi desenvolvida a pesquisa, buscando salientar seus atributos biológicos, o perfil da comunidade residente e as peculiaridades locais. No capítulo III estão descritos os objetivos deste trabalho. No capítulo IV estão descritos os referenciais teóricometodológicos que delinearam a construção metodológica da pesquisa, encerrando desta forma a Parte I da dissertação.

Na Parte II, é tratado no seu único capítulo (V), o referencial teórico que serve de fonte para esta dissertação.

E finalmente a Parte III em que estão dispostos os capítulos VI e VII em que serão apresentados os resultados e discussão dos mesmos e as Considerações finais respectivamente. No Capítulo VI - Considerações Finais serão propostos alguns elementos, sem ter a pretensão de esgotar as possibilidades, que venham de alguma forma contribuir para a sustentabilidade ambiental da APA de Sousas e Joaquim Egídio ou mesmo para outras localidades que de alguma forma tenham algo em comum à área estudada. 


\section{CARACTERIZAÇÃO DA ÁREA DE PROTEÇÃO AMBIENTAL DE SOUSAS E JOAQUIM EGÍDIO}

Este capítulo foi extraído da "Proposta do Programa de Educação Ambiental da Apa de Sousas e Joaquim Egídio " a qual foi elaborada pelos alunos da disciplina "Educação, Ambiente e Floresta", sob orientação do Professor Marcos Sorrentino durante o $2^{\circ}$ semestre de 2000, na Esalq.

\subsection{Conceituação de Áreas de Proteção Ambiental}

No início da década de 1980, com a instituição da Política Nacional de Meio Ambiente, surgiram diversos instrumentos destinados à proteção do meio ambiente, dentre os quais, uma nova categoria de unidade de conservação: a Área de Proteção Ambiental (Apa).

As Apas são definidas como "unidades de conservação que visam a proteção da vida silvestre de bancos genéticos e de espécies raras da biota regional, bem como dos demais recursos naturais, através da adequação e orientação das atividades humanas na área, promovendo a melhoria da qualidade de vida da população" (Brasil, 1987; São Paulo, 1992). Seu objetivo principal é conservar a diversidade de ambientes, de espécies e de processos naturais, pela adequação das atividades humanas às características ambientais da área, seus potenciais e limitações. Dentre seus objetivos específicos encontram-se a proteção da cobertura vegetal (conservação da vegetação nativa e reabilitação de áreas degradadas), proteção da fauna silvestre e seus locais de arribação, manutenção e melhoria da qualidade dos recursos hídricos, proteção dos 
recursos do solo e subsolo, promoção de educação ambiental para a população e sua integração nas práticas conservacionistas (Brasil, 1987).

Distinguem-se das demais categorias de unidades de conservação pois, permitem a manutenção das atividades humanas existentes na região e incluem terras de propriedade privada ou qualquer outra situação fundiária. Elas inovam ao estabelecer, por lei, apenas restrições ao direito de propriedade, controlando total ou parcialmente as iniciativas privadas que constituam ameaças ao ambiente (Nogueira Neto, 1982).

O processo de implantação de uma Apa envolve diversas etapas e procedimentos legais e técnicos. Sua simples criação, através de instrumento legal apropriado (lei, decreto, resolução ou portaria), constitui apenas o primeiro passo, insuficiente para garantir o cumprimento de seus objetivos básicos. Isto só é atingido com a regulamentação das leis e decretos que a criaram e a implantação de um complexo sistema de gestão ambiental (São Paulo, 1991a). Devem ser definidos criteriosamente os instrumentos gerenciais, como 0 zoneamento ambiental, o plano de gestão e os instrumentos fiscais e financeiros (São Paulo, 1992).

Os zoneamentos ecológicos-econômicos das Apas são imprescindíveis para assegurar o uso adequado do solo, para o disciplinamento e orientação às atividades humanas, que devem ser compatíveis com as potencialidades do meio físico, convergindo para formas adequadas ao desenvolvimento sustentado e participativo (SÃO PAULO, 1992). Baseado em pesquisas básicas sobre o relevo, geomorfologia, solos, hidrologia, flora, fauna e fatores antrópicos, e tendo como orientação geral as classes internacionais de uso dos solos, o zoneamento de uma Apa estabelece:

- Zonas de Preservação da Vida Silvestre (incluídas as Áreas de Preservação Permanente definidas pelo Código Florestal);

- Zonas de Uso Extensivo: pecuária e reflorestamento;

- Zonas de Uso Intensivo: agricultura mecanizada;

- Zonas de Uso Especial: uso urbano e para lazer 
Para viabilizar a efetivação dos objetivos de uma Apa e de seu zoneamento, um plano de gestão deve definir programas, planos de ação e projetos específicos de desenvolvimento, como programas de recuperação de áreas degradadas, programas de educação ambiental, sistemas de fiscalização das atividades humanas, programas de saneamento básico, programas de monitoramento ambiental e de pesquisas científicas.

\subsection{Regulamentação da Apa de Sousas e Joaquim Egídio}

Uma das primeiras manifestações públicas que apresentaram propostas específicas para o desenvolvimento da região e a implantação de instrumentos legais de proteção ambiental nos Distritos de Sousas e Joaquim Egídio ocorreu em 1991, por ocasião do Primeiro Fórum Ecológico de Sousas.

Em maio de 1993, através do Decreto Municipal no 11.172, foram criadas as APAs de Sousas e Joaquim Egídio, propondo o futuro estabelecimento de critérios e normas legais de uso e ocupação do solo e de proteção e recuperação do patrimônio existente. No mesmo ano a Secretaria Municipal de Planejamento e Meio Ambiente (SEPLAMA) desenvolveu uma "Proposta Preliminar de Macrozoneamento Ambiental" das Apas. Por iniciativa da Prefeitura Municipal foram também formados grupos de trabalho sobre o patrimônio natural, cultural e de educação ambiental, que se reuniram periodicamente durante seis meses, discutindo os problemas e potencialidades da região. Decorrente dessas iniciativas foi instituída a organização não-governamental "Centro de Referência Ambiental de Joaquim Egídio" (Santana, 1994).

Em 1995 a Prefeitura Municipal de Campinas apresentou à comunidade uma reformulação do Plano Diretor de Campinas. Segundo esta proposta, as duas unidades de conservação instituídas pelo decreto municipal foram unificadas em uma única Apa e seus limites ampliados, adicionando aos Distritos de Sousas e Joaquim Egídio a região do interflúvio dos Rios Atibaia/Jaguari (porção "entrerios"). 
O Plano Diretor estabeleceu 16 diretrizes e critérios gerais para 0 ordenamento territorial da Apa e determinou a elaboração de um Plano Local de Gestão com diretrizes estratégicas específicas, que foi concluído pela SEPLAMA e apresentado à comunidade em 1996. Além de um zoneamento, o plano propõe regulamentações para os diversos tipos de usos e ocupações das terras e instrumentos para a gestão da Apa, servindo de subsídio para a elaboração de um projeto de lei que, até o momento, ainda não foi aprovado pela Câmara dos Vereadores de Campinas.

\subsection{Caracterização da Apa de Sousas e Joaquim Egídio}

A Apa de Sousas e Joaquim Egídio (Campinas/SP) está localizada no quadrante nordeste do município, abrangendo uma área de $223 \mathrm{~km}^{2}$, no interflúvio dos rios Atibaia e Jaguari, apresentando altitudes que variam de 550 metros na planície do Atibaia a 1078 metros na Serra das Cabras. Representa aproximadamente $28 \%$ da área do município da Campinas, fazendo divisa com os municípios de Jaguariúna, Pedreira, Morungaba e Valinhos. Compreende integralmente os distritos de Sousas e Joaquim Egídio que, juntos, correspondem a 2/3 da área total da Apa. Os restantes $1 / 3$ são ocupados pelos bairros Carlos Gomes, Jardim Monte Belo e Chácaras Gargantilha, também denominada "entrerios", no interflúvio dos rios Atibaia e Jaguari.

Comparada às demais regiões do município de Campinas, a Apa/SJE apresenta aspectos diferenciados quanto ao uso e ocupação do solo, com menores índices de urbanização, baixa concentração populacional e expressiva concentração de fazendas e áreas verdes.

Os padrões de drenagem da Apa são influenciados pela natureza e disposição das camadas rochosas, pela resistência litológica, pelas diferenças de declividade e pela evolução geomorfológica da região. A Apa de Sousas e Joaquim Egídio caracteriza-se por uma rede de drenagem com densidade alta a média e padrões predominantes subdendrítico e subparalelo. Esta área é bem mais rica em recursos hídricos superficiais que o restante do município de 
Campinas. Ali se localizam duas bacias, as dos rios Atibaia, constituída por 41 microbacias, e Jaguari, com 17 microbacias, apresentando riqueza de nascentes de cursos d'água. O Rio Atibaia, principal manancial do município, é responsável por $80 \%$ do fornecimento da água para abastecimento de Campinas. A captação é realizada na área do distrito de Sousas (Mattos, 1996).

Os terrenos são frágeis e muito susceptíveis à erosão em função da composição das rochas e do solo, bem como pela acentuada declividade do relevo. Devido a esse conjunto de características, as práticas agrícolas e demais formas de ocupação requerem cuidados especiais.

A Apa de Sousas e Joaquim Egídio concentra significativos $48 \%$ dos remanescentes vegetais do município (Mattos, 1996), representando $11 \%$ do território da Apa. Os fragmentos de matas nativas de maior extensão estão localizados na Fazenda Ribeirão Cachoeira (223,7 hectares) e Fazenda Sant'Ana (97 hectares), e a Fazenda Santa Genebra, que hoje é uma Reserva Municipal. Nelas encontram-se espécies nobres da flora brasileira, tais como jequitibás, perobas-rosa e cedros.

A flora presente na Apa de Sousas e Joaquim Egídio desempenha a função de "elo de ligação" entre as Apa's de Cajamar, Cabreúva, Jundiaí e Piracicaba/Juqueri-Mirim, já existentes nas regiões vizinhas a Campinas, dando continuidade espacial à proteção dos atributos naturais (vegetação natural, solos, mananciais e recursos minerais), paisagísticos e culturais relevantes desta porção Sudeste do Estado de São Paulo. Contribui assim para prevenir extinções e garantir a manutenção de mecanismos reguladores de equilíbrio ambiental.

Os corredores naturais de vegetação (ligações entre fragmentos isolados), representados pelos cursos d'água e faixas contínuas de vegetação ripária ao longo deles, desempenham papel fundamental na distribuição de espécies animais, sementes, recursos, além da regulamentação da movimentação da água e materiais. Eles encontram-se bastante alterados na Apa de Sousas e Joaquim Egídio. Estudos de Mattos (1996) atestam que a maior parte das matas ciliares foi erradicada ou apresenta pouca conectividade ao longo dos principais rios e ribeirões, prejudicando seu papel de condutor para espécies típicas destes 
ambientes e também o controle do fluxo de sedimentos e poluentes aos cursos d'água. Segundo a mesma autora, um programa de implantação de corredores via recuperação e reflorestamento destas margens deveria ser, portanto, uma prioridade do Plano de Gestão.

Os remanescentes da vegetação natural ainda existentes na Apa são de grande importância para a fauna, pois representam hoje um refúgio para várias espécies. Mesmo quando isolados e de pequena extensão, muitas vezes constituem a única fonte de abrigo, alimentação e nidificação para certos grupos animais. No interior das matas nativas ou mesmo nas pastagens e plantações da região é possível encontrar animais silvestres, onde habitam gatos selvagens (jaguarundi e jaguatiricas), macacos (bugios), lontras, maritacas, seriemas e biguás. Segundo levantamento do Ibama existem no local 300 espécies de vertebrados, 200 das quais representadas por aves.

A migração estrangeira, principalmente de origem italiana, nos distritos, promovida para dar sustentação ao desenvolvimento rural no início do século XX, trouxe consigo tradições sociais e religiosas que se mesclam às tradições locais. Em Joaquim Egídio é realizada desde 1926, no mês de agosto, as comemorações da festa de São Roque e também a do padroeiro São Joaquim, com intensa participação popular.

Merece menção a presença na Apa de importantes centros de saúde, com trabalhos reconhecidos nacional e internacionalmente. O Instituto Souza Novaes, localizado em Sousas, fundado em 1991, atua na recuperação de dependentes químicos. Foi premiado pela American Society pelo trabalho voluntário desenvolvido junto à quimiodependentes (Jornal Correio Popular, Campinas/SP, 17/12/1999).

O Hospital Psiquiátrico Cândido Ferreira, em Sousas, trabalha em parceria com o Conselho Municipal dos Direitos da Criança e do Adolescente, contando com um abrigo de atendimento e recuperação a menores viciados em drogas. Nesses locais as crianças e adolescentes participam de atividades lúdicas, esportivas e educacionais (Jornal Correio Popular, Campinas/SP, 10/11/1999). 
O Hospital Psiquiátrico Tibiriçá, localizado em Joaquim Egídio, iniciou em outubro de 2000 uma experiência inovadora, criando repúblicas para exmoradores do hospital, tendo o acompanhamento de profissionais da área médica. O Hospital Tibiriçá, assim, adotou um sistema de atendimento à saúde mental considerado modelo pela Organização Mundial de Saúde. Até o final de 2001 todos os pacientes deixarão o hospital para viverem nas moradias (Jornal Correio Popular, Campinas/SP, 15/10/00).

A arquitetura das áreas rurais e das urbanizadas presentes nos distritos constitui rico patrimônio histórico, estético e cultural. Na Apa existem três usinas hidrelétricas, todas construídas no início do século XX: a Usina do Macaco, a Usina Jaguari e a Usina Salto Grande, que se encontram em funcionamento e em bom estado de conservação. Foram construídas entre os anos de 1911 e 1912, de acordo com a arquitetura inglesa. O conjunto paisagístico composto por essas edificações e seu entorno são de grande importância e mereceu recomendações de preservação por parte do CONDEPACC - Conselho de Defesa do Patrimônio Artístico e Cultural de Campinas.

As fazendas, suas edificações e o contexto cênico em que se inserem as estações, pontes e trilhos de ramais ferroviários (desativados), os núcleos urbanos e as usinas hidrelétricas, constituem memórias de importantes fases históricas, revelando valores e o modo particular como se vem procedendo o desenvolvimento dessa região de Campinas.

As atividades agrossilvopastoris representam a principal forma de uso do solo e fonte econômica da Apa municipal. A cultura cafeeira constituiu-se no século XIX a principal atividade econômica local, financiando a construção das sedes de fazendas, ferrovias e demais edificações que hoje constituem 0 patrimônio histórico da região.

Atualmente, o reflorestamento com eucalipto e as pastagens predominam na paisagem rural, ocupando respectivamente $10 \%$ e $65 \%$ da extensão da Apa, aproximadamente. Ao norte da zona agropecuária definida no Plano de Gestão da Apa encontra-se a área com maior potencial agrícola, principalmente em função do predomínio de declividades mais suaves e das características do solo, em 
geral mais profundos, permeáveis e menos erodíveis, comportando um uso mais intensivo. Este potencial é percebido pelos agricultores da região, que usam a terra com culturas hortícolas (tomate), anuais (milho), semi-perenes (cana-deaçúcar e mandioca) e perenes (café e citrus). São raras as práticas de culturas consorciadas.

Portanto, nota-se que, diversamente do processo acentuado de industrialização do município de Campinas, Sousas e Joaquim Egídio mantiveram sua tradição rural, com uma diversificação produtiva - substituição dos cafezais por outras culturas e por pastagens. Os dados referentes ao crescimento populacional demonstram que as taxas de urbanização e adensamento da região da Apa são sensivelmente inferiores às registradas nas demais regiões do município. Constitui uma área predominantemente rural, sendo apenas 13\% caracterizados como zona urbana.

Suas características naturais somadas ao processo de ocupação diferenciada, caracterizada pela baixa densidade demográfica, conferem ao local um patrimônio ambiental (físico, biótico e cultural) de especial interesse para o município e região. Tais atributos merecem ser preservados e servir como elementos educacionais para a conservação do ambiente, por ser um laboratório vivo que possibilita o contato com diferentes ecossistemas, podendo ser estudados e compreendidos por meio de processos de educação formal e não formal.

\subsection{Degradação Ambiental na Apa de Sousas e Joaquim Egídio}

Por estar situado numa das regiões de maior crescimento econômico do Brasil, são grandes as pressões de uso do solo, constituindo riscos aos patrimônios naturais, históricos e culturais.

O Rio Atibaia, principal manancial do município e que recorta a Apa é receptor de despejos urbanos e industriais, de forma direta ou através de seus afluentes, tanto em Campinas como em Valinhos e Vinhedo. Em Campinas seus 
afluentes são o Ribeirão das Cabras, na margem direita, e o Ribeirão Anhumas, na esquerda.

A penetração humana na região de Campinas, iniciada no século XVIII, foi sempre predatória, levando a uma grande alteração da cobertura vegetal original. Os campos passaram a dominar a paisagem rural e, dos cerrados, são encontrados hoje, no município, apenas alguns vestígios. Quanto às florestas, quase nada restou: a demanda por madeira, lenha e espaço para outros usos (agricultura, pastagens e áreas urbanas) levou à quase total devastação destas formações. Atualmente elas ocupam apenas 4,12\% da área total do município (Embrapa, 1993), sendo representadas por cerca de 114 manchas, distribuídas nas zonas urbana e rural (Batistella et al., 1995).

Apesar da relativa conservação dos remanescentes da vegetação natural encontrados na Apa/SJA, não são encontradas matas naturais e primitivas ainda intocadas naquele local. Mesmo as manchas mais preservadas apresentam sinais de interferência antrópica, conseqüência da dinâmica agropecuária que se instalou no local através de um longo processo de ocupação humana. Assim, diversos estágios de regeneração/alteração da vegetação natural. Apesar dos sinais de alteração das matas, uma análise qualitativa do recobrimento aerofotogramétrico de 1972 mostra que, principalmente os fragmentos maiores, sofreram pouca alteração de sua área total no período 1972-1996. Já os fragmentos de menor extensão eram mais numerosos em 1972 e apresentaram maior grau de alteração de área e forma neste período, além de erradicação em alguns pontos (Mattos, 1996).

As matas ciliares aparecem em apenas 0,49\% da área total da Apa Muito alteradas e bastante isoladas umas das outras, as poucas manchas de matas ciliares existentes na área possuem alto interesse biológico e altas prioridades de proteção e manejo. Além de fornecer abrigo, alimentação e local de reprodução para uma fauna específica, as matas ciliares desempenham um papel ecológico fundamental: garantem a estabilidade das margens dos cursos d'água, controlando o fluxo de sedimentos, a qualidade das águas e, como conseqüência, a estabilidade e riqueza das populações aquáticas, e são também importantes 
pontos de lazer para os visitantes e moradores da Apa. Quanto à fauna que habita os fragmentos vegetais da Apa, as maiores ameaças têm sido a caça, introdução e reintrodução de espécies.

Apresentando um uso do solo da Apa conflitivo com a legislação ambiental, observa-se que $82,53 \%$ dos mais de 5 mil hectares de Áreas de Preservação Permanente da Apa - definidas pelo Código Florestal, seja ao longo de rios, em torno de reservatórios, nos topos de morros ou encostas íngremes, tiveram sua cobertura vegetal eliminada e substituída por agroecossistemas ou áreas urbanas. Nota-se também transgressão às leis pelo generalizado desrespeito à manutenção de pelo menos $20 \%$ da área das propriedades rurais com Reservas Legais.

De acordo com Mattos (1996), as áreas mais problemáticas da Apa devido ao desrespeito à legislação - para as quais deveriam ser formulados programas urgentes de recuperação, são a Bacia do Ribeirão das Cabras e o entorno da represa Jaguari. Na primeira, a faixa de preservação permanente ao longo dos rios encontra-se severamente alterada, desde as cabeceiras dos cursos primários até a foz, no núcleo urbano de Sousas. Além disso, usos intensivos das terras e áreas urbanizadas concentram-se às margens do Ribeirão das Cabras, aumentando os riscos de impactos ambientais. Quanto à Represa Jaguari, o desmatamento de suas margens, combinado à natureza dos solos e formas de relevo predominantes, constitue sérios riscos de erosão, assoreamento do reservatório e comprometimento da qualidade deste potencial manancial de abastecimento.

Os núcleos urbanos de Sousas e Joaquim Egídio caracterizam-se pela presença de áreas densamente construídas e quase totalmente parceladas e ocupadas. Observa-se um crescimento da impermeabilização do solo, algumas atividades industriais potencialmente poluidoras $\equiv$ hçamento de esgoto in natura no Rio Atibaia, Ribeirão das Cabras e Ribeirão dos Pires, além de pontos susceptíveis a enchentes ao longo do Ribeirão das Cabras e do Rio Atibaia. Também há o acúmulo de lixo lançado em terrenos baldios, margens e leitos dos 
rios e córregos, relatados segundo o Jornal Correio Popular (24/10/98), que resultam na infestação de ratos em diversos desses bairros urbanizados.

A demanda desordenada por moradias nessas áreas tem resultado no surgimento de favelas e ocupações. Loteamentos rurais com finalidade urbana e também alguns na zona urbana encontram-se embargados por não atenderem às determinações da atual legislação de parcelamento do solo. Estes empreendimentos, particularmente os clandestinos, instalados sem a aprovação da Prefeitura, causam impactos como erosão, assoreamento dos corpos d'água e remoção de vegetação nativa. A grande demanda da população de alto poder aquisitivo, de Campinas e outras cidades próximas, por áreas de moradia e recreio, resultam em grande valorização desses empreendimentos imobiliários.

A atividade mineraria da região é de caráter tanto extrativista (argila, brita, areia, rocha ornamental/cantaria e água) como de transformação. A extração de argila está associada à indústria de cerâmica, representada na região por olarias (produção quase totalmente manual de tijolos) e cerâmicas (fase industrial). A extração é normalmente feita em planícies de inundação de córregos e riachos, pela escavação de valas a céu aberto ou cavas secas. São processos geralmente mal conduzidos, que usam procedimentos rudimentares e geram impactos ambientais como extração ou comprometimento da vegetação na área explorada, remoção das camadas superficiais do solo, alteração da paisagem e do perfil hídrico, assoreamento dos cursos d'água, erosão e formação de lagoas nas cavas abandonadas. Em 1995, muitos destes empreendimentos estavam paralisados ou abandonados, mas foram identificados alguns em atividade na porção central da APA e no limite com Jaguariúna.

A extração de areia, assim como a de argila, é um processo rudimentar, sendo muitas vezes de forma clandestina ou irregular. É feita normalmente em portos de areia, onde o material é dragado do leito dos rios (Atibaia e Jaguari) por meio de bombas instaladas em balsas flutuantes. Também é feita a extração de areia associada à argila, em cavas submersas das planícies fluviais, acarretando os mesmos impactos mencionados acima. Foram identificados na Apa dois portos de areia ativos, na Represa do Rio Jaguari, e diversos desativados ou com 
funcionamento intermitente, mas cujos impactos na paisagem ainda são perceptíveis (Mattos, 1996).

A pedreira Cowan, localizada na Apa, manteve-se em funcionamento por vários anos, atendendo principalmente à demanda de material para as obras de duplicação da Rodovia D. Pedro I e do anel viário, mas foi paralisada. Ela produzia brita, a partir das rochas graníticas e também material arenoso utilizado em obras de pavimentação. Seu impacto sobre o meio ambiente foi expressivo: alteração da paisagem, desmatamento, retirada de solos superficiais, assoreamento de cursos d'água e processos erosivos. Quanto ao funcionamento, haviam também problemas de ruídos e vibrações causados por detonações e geração de poeira. Mesmo após sua paralisação, não foram tomadas medidas para a recuperação da área degradada.

Pedreiras menores atuam na região, na produção de rochas talhadas (paralelepípedos para calçamento de ruas) e rochas ornamentais (rochas polidas para revestimento e ornamentação), extraídos de matacões de granito. Os principais impactos desta atividade são o desmatamento, alterações da topografia, produção de grande número de rejeitos que causam instabilidade nas encostas e entulham drenagens, ruídos e vibrações provocados pelas explosões. Este tipo de exploração mineraria representa especial risco ao funcionamento do Observatório Municipal de Campinas Jean Nicolini, no limite oeste da Apa. Pedreiras em funcionamento ainda podem ser identificadas, apresentando sinais de alteração da paisagem nas Serras das Cabras e dos Cocais.

Os solos Podzólicos, predominantes na região de Sousas e Joaquim Egídio, apresentam alta susceptibilidade aos processos erosivos, devido às baixas taxas de infiltração (Oliveira, 1980). Como conseqüência da retirada da cobertura vegetal natural, sua substituição por pastagens, loteamentos residenciais irregulares, abertura de estradas, atividades minerarias e cultivos agrícolas que não adotam práticas de conservação dos solos (IPT, 1991), observa-se que muitos pontos da Apa, particularmente em meia-encosta de áreas com relevo movimentado, processos erosivos em estágios avançados, inclusive com formação de voçorocas. O Condomínio Colinas do Ermitage é um exemplo 
das áreas mais críticas, concentradas na Bacia do Ribeirão das Cabras. Também resultante do desmatamento e erosão das bacias, assoreamento e enchentes localizadas são problemas encontrados nos ribeirões das Cabras e dos Pires (Pires Neto, 1995).

Em termos agronômicos 56,8\% da área total da Apa apresenta uso atual da terra adequado, na qual a existência de cultivos anuais, semi-anuais, perenes, silvicultura e, principalmente, pastagens, não representam comprometimento aos solos e recursos naturais pois as terras têm capacidade de uso compatíveis com as demandas dessas práticas agrossilvopastoris.

A prática de queimadas periódicas para o manejo de pastagens é um impacto significativo da agropecuária da região.

Em algumas áreas, no entanto, concentradas na porção sul e leste da Apa, a existência de culturas anuais e pastagens, com os sistemas de cultivo adotados na região, é considerada pouco adequada, tendo em vista que os recursos naturais disponíveis são limitados e não compatíveis com as demandas culturais. Nestas áreas, que representam 10,83\% da Apa, para evitar a degradação dos recursos naturais, é necessária a adoção de práticas de manejo e conservação dos solos ou a substituição do uso das terras.

As terras subutilizadas representam 12\% da Apa, nas quais o uso atual está aquém do que os recursos naturais permitiriam. São considerados 2,28\% da área da Apa como sobreutilizados, com grandes cultivos agrícolas ao longo da Estrada das Cabras e em áreas menores, nos limites leste e norte da Apa. Correspondem a terras ocupadas por culturas anuais e perenes, principalmente café. Nestes casos, se utilizadas técnicas e cultivos intensivos, sem prática de conservação, é provável que ocorram danos aos solos e baixas produtividades. Pastagens ou reflorestamentos seriam mais adequados nestas porções da Apa.

Os restantes 11\% da Apa, excluídas as áreas urbanas e corpos d'água, são matas mesófilas, matas ciliares e campos de várzeas que, mesmo quando localizadas em terras com capacidades de uso agrossilvopastoril $\equiv$ ão considerados usos adequados. 


\subsection{Mobilização Comunitária/Ambientalista nos Distritos}

A partir do início dos anos 90 tem-se intensificado a mobilização da comunidade e do poder público local em defesa do patrimônio natural, cultural e histórico da região de Souzas e Joaquim Egídio. Os grupos locais vêm atuando no propósito de divulgar a importância da riqueza ambiental da região, os riscos de degradação e propondo ações coletivas pela melhoria da qualidade ambiental. O Jornal Correio Popular (Campinas/SP) tem veiculado notícias referentes a algumas dessas iniciativas:

a) Movimento Reviva o Rio Atibaia (Jornal Correio Popular, Campinas/SP, 28/10/99)

Criado em 1997 e coordenado pela Associação dos Pescadores da Região, Associação de Remo e Associação de Proteção Jaguatibaia, com apoio da indústria farmacêutica Merck Sharp \& Dohme.

Principais atividades realizadas: Seminário para discussão da situação da Apa de Sousas e Joaquim Egídio, onde uma carta em defesa da Apa foi aprovada ao final do encontro, contando com a participação de representantes do poder público e organizações comunitárias e ambientais. Em outubro de 1999 foi realizada a terceira edição do evento "Reviva o Rio Atibaia". Ocorreram debates referentes ao processo de regulamentação e instalação da Apa dos Distritos, além de atividades tais como exposição fotográfica, distribuição de gibis, exposição de material reciclado do Centro de Saúde Cândido Ferreira, distribuição de mudas de árvores nativas, soltura de alevinos e barqueata de limpeza do rio, recolhendo detritos acumulados nas margens e em seu leito.

b) Grupo Patrulheiros Ecológicos (Jornal Correio Popular, Campinas/SP, $11 / 01 / 00)$ 
O objetivo do grupo é formar um quadro de cem jovens visando auxiliar o Corpo de Bombeiros. Tem por finalidade promover atividades que desenvolvam a conscientização ecológica. Nos finais de semana são organizados passeios pela mata, com a participação de moradores de Campinas e Sousas.

Dentre as atividades do grupo estão as de apoio a primeiros socorros a pessoas perdidas nas matas e combate a incêndios florestais como auxiliares de bombeiros. Além das atividades preventivas o grupo pretende contribuir para a diversão, particularmente pelo ecoturismo.

c) Grupo Patrulha Aero-Civil (Jornal Correio Popular, Campinas/SP, 27/05/00)

É uma Organização Não-Governamental presente em Campinas desde 1950, tendo tomado a iniciativa de reunir integrantes da comunidade do Distrito de Sousas para o treinamento visando à formação de uma equipe de brigada civil especializada em resgate de vítimas de acidentes cotidianos e combate a danos causados ao meio ambiente, fornecendo amparo pré-hospitalar e promovendo ações preventivas e sociais.

O grupo já conseguiu apoio da iniciativa privada, da sub-prefeitura local e da própria prefeitura municipal. A intenção agora é também realizar projetos educacionais ecológicos.

d) Colégio Ave Maria (Jornal Correio Popular, Campinas/SP, 04/10/00)

A instituição de ensino coordena o projeto Semear, que ocorre desde 1998. Tem por objetivo a recuperação do Rio Atibaia pelo plantio de mudas de espécies nativas em suas margens.

e) Rádio Comunitária (Jornal Correio Popular, Campinas/SP, 17/05/98) 
A Associação de Moradores de quinze bairros de Sousas tem o projeto de instalar uma rádio comunitária, que tem por finalidade assegurar um espaço de reivindicações dos moradores e a divulgação de acontecimentos culturais e sociais.

f) Associação Campineira de Ação Ecológica e Rotaract Club de Campinas-Sul (Jornal Correio Popular, Campinas/SP, 21/04/91)

As entidades promoveram o Primeiro Fórum Ecológico de Sousas, em 1991, tendo por objetivos a mobilização da população do Distrito de Sousas para a implementação de projetos ecológicos e despertar a atenção dos moradores dos Distritos e do município de Campinas em relação aos problemas causados pela ocupação desordenada daquele local.

Um instrumento jurídico utilizado para oferecer proteção a esse local foi a sua conversão numa unidade de conservação, particularmente uma Área de Proteção Ambiental.

\subsection{Centro de Educação Ambiental de Joaquim Egídio: "Estação} Ambiental"

O Centro de Educação Ambiental de Joaquim Egídio já se encontra em atividade. Localizado na antiga estação de bonde do Distrito, encontra-se equipado com retroprojetor, TV, videocassete, 28 cadeiras e armários. As salas foram destinadas a atividades voltadas a Educação Ambiental e Ecoturismo. Também estão expostos painéis de trabalhos realizados pelas escolas da região.

O Centro de Educação Ambiental ainda não está sendo caracterizado como uma referência ambiental pelos moradores locais e visitantes, sendo percebido por eles como um museu ou biblioteca. 


\section{OBJETIVOS}

\subsection{Objetivo geral}

Contribuir para a produção de conhecimentos que subsidiem atividades de educação ambiental e turismo rural em Apas ou em áreas que possuam patrimônio histórico e cultural.

\subsection{Objetivos específicos}

- Realizar uma intervenção educacional junto a um grupo de estudantes e sistematizar as informações nela captadas.

- Verificar nesse grupo de estudantes a relação estabelecida entre os problemas ambientais e a responsabilidade pela sua geração e sua solução.

- Caracterizar a compreensão a respeito de meio ambiente, natureza, problemas ambientais, desejos e necessidades frente à temática ambiental desse grupo de estudantes.

- Disponibilizar alguns elementos que possam contribuir para programas de educação ambiental em Áreas de Proteção Ambiental, visando uma maior sensibilização dos envolvidos. 


\section{METODOLOGIA}

Esta pesquisa foi realizada na área da Fazenda Santa Maria, localizada no subdistrito de Joaquim Egídio, que pertence ao município de Campinas, situado no Centro-oeste do estado de São Paulo Estabelecida entre os municípios de

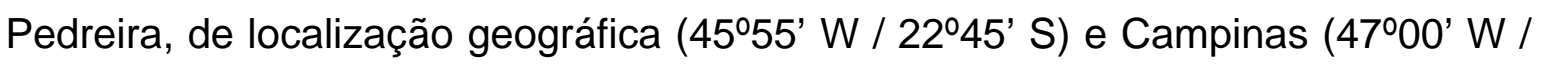
22050' S).

A fazenda Santa Maria é um lugar com paisagens que misturam o passado e o presente. A construção da sede data de 1831 e a restauração realizada pelos proprietários terminou em 1990, porém não foram obedecidos todos os padrões estéticos e arquitetônicos do período, portanto alguns cômodos não mantiveram suas características originais. Algumas modificações estruturais foram necessárias para garantir que a sede se mantivesse em pé, porém a sensação que provoca é de uma viagem no tempo.

O porão da fazenda nos dá a idéia de como viviam os escravos, as paredes de pau-a-pique e muitos outros ambientes nos remetem há um tempo em que tudo era muito diferente, com menor massificação de idéias e necessidades.

É uma típica fazenda para se pensar o turismo dito rural, além de sua sede, tem também algumas práticas que também são atrativos como: café e horta orgânicos, pomares e criação de gado Simmental.

Buscando inicialmente entender a percepção de alunos da Escola Municipal de Ensino Fundamental "Professora Ângela Cury Zackia", que em sua maioria nasceram e foram criados em uma área que preservou algumas de suas características originais (aproximadamente $60 \%$ do que sobrou de mata nativa da região está dentro da $\mathrm{Apa}$, há diversas fazendas históricas belíssimas, cachoeiras, fauna silvestre e flora são alguns dos seus atributos biológicos) que 
embora este distrito pertença a uma metrópole como Campinas, suas peculiaridades são sozinhas algo que instiga e atrai como foco a se pesquisar. Haveria uma percepção/relação com a natureza que pudesse sensibilizar por si só aqueles alunos? Ou não seriam sensibilizados pelos atributos locais? Como a escola vem trabalhando seu entorno, já que os alunos são moradores da comunidade que envolve a mesma? Vários eram os questionamentos que instigavam a investigação.

O método de pesquisa foi sendo construído ao longo de todo o processo. Vários autores alimentaram-na, todavia em momento nenhum, cada uma das etapas percorridas deixou de ser pensada e programada, porém foram sendo feitas adaptações respeitando as características locais.

Segundo Becker,

“Os princípios gerais (...) de metodologia são uma ajuda, mas sendo genéricos, não levam em consideração as variações locais e peculiaridades que tornam este ambiente e este problema aquilo que são de um modo único"(Becker, 1993:13).

O diálogo com a metodologia ocorreu durante todo o processo e a pesquisa permeou nos referenciais do estudo de caso, das pesquisas qualitativa e quantitativa, da pesquisa-ação e do planejamento incremental. Foram utilizadas também ferramentas que auxiliaram o processo de pesquisa como: entrevistas semi-estruturadas e aplicação de questionários com os atores envolvidos na pesquisa.

Segundo Patton (1990), pode-se dizer que houve uma triangulação, que o autor define como sendo:

"a combinação de metodologias no estudo do mesmo fenômeno ou programa de pesquisa. Podem ser usados vários métodos ou dados, incluindo usar abordagens qualitativas e quantitativas". 
A seguir será feita uma descrição do método e técnicas que orientaram esta pesquisa e posteriormente, os caminhos trilhados para sua realização.

\section{Pesquisa Qualitativa}

De acordo com Ludke \& André (1986), a pesquisa qualitativa apresenta cinco características básicas que servem como referencial:

"1. o ambiente natural como fonte de dados e o pesquisador como principal instrumento; 2. os dados coletados são predominantemente descritivos; 3. a preocupação com o processo é muito maior do que com o produto; o "significado" que as pessoas dão às coisas e à sua vida são focos de atenção especial do pesquisador 4. o pesquisador deve estar atento para captar a "perspectiva dos participantes" e 5. a análise de dados tende a seguir um processo indutivo" (Ludke \& André, 1986:11).

E ainda, a pesquisa qualitativa "envolve a obtenção de dados descritivos, obtidos no contato direto do pesquisador com a situação estudada, enfatiza mais o processo do que o produto e se preocupa em retratar a perspectiva dos participantes" (Bogdan \& Bilklen, 1982).

\section{Sobre o Estudo de Caso}

O estudo de caso tem como estrutura básica a compreensão de uma unidade dentro de um sistema amplo de dimensões complexas, ou seja, é o estudo de um caso que deve ser bem delimitado, com contornos claramente definidos, cujo interesse centra-se no que tem de exclusivo, considerando-se o contexto em que está inserido. 
Segundo Triviños, (1987) o estudo de caso "(...) É uma categoria de pesquisa cujo objeto é uma unidade que se analisa profundamente".

\section{Sobre a pesquisa-ação}

A pesquisa-ação envolve a interação entre os pesquisadores e as pessoas implicadas diretamente na situação investigada, resultando em uma ordem de prioridade dos problemas a serem pesquisados e pessoas implicadas nas soluções a serem encaminhadas sob a forma de ação concreta. O objeto de investigação não é constituído pelas pessoas e sim pela situação social e pelos problemas de diferentes naturezas encontradas e o objetivo é esclarecer os problemas da situação e durante o processo há o acompanhamento das decisões, das ações e de toda a atividade intencional dos atores da situação e a pesquisa não se limita a uma forma de ação: pretende-se aumentar o conhecimento dos pesquisadores e o conhecimento ou "nível de consciência" das pessoas (Thiollent, 1986).

\section{Sobre o Planejamento Incremental Articulado}

Do planejamento incremental articulado pode-se salientar dois pontos sobre os quais se baseia esta estratégia de planejamento:

"1. Nenhum sistema social pode ser transformado de uma vez, partindo de um estado inicial e chegando a um estado desejado. A transformação tem de ser gradual e cada mudança real que ocorre no sistema pode modificar a definição do estado desejado. 2. As características do estado desejado devem ser estabelecidas de modo a se constituírem em critérios que permitam a avaliação de cada mudança incremental. Estas 
características fornecem uma direção geral que articula as ações tomadas."

\section{A coleta dados}

Algumas técnicas de coleta de dados foram utilizadas como: questionários, entrevistas semi-estruturadas e análise de documentos disponibilizados como: documentos oficiais, dissertações e teses que abrangeram o local, mapas.

\section{Entrevistas semi-estruturadas}

Segundo Ludke \& André (1986) "a entrevista semi-estruturada se desenrola a partir de um esquema básico, porém não aplicado rigidamente, permitindo que o entrevistador faça as necessárias adaptações", auxiliará no entendimento da relação.

Além disso, a entrevista cria uma relação de interação, proporcionando uma atmosfera de influência recíproca entre quem pergunta e quem responde.

\section{Questionários}

Lakatos (1992) aponta algumas vantagens e desvantagens sobre o uso do questionário. As vantagens são: atividade menos dispendiosa, economiza tempo e se obtém grande número de dados; atinge maior número de informantes; tem menor risco de distorção; e natureza impessoal do instrumento, facilitando a avaliação. As desvantagens são: perguntas sem resposta; influências de uma questão sobre a outra; impossibilidade de apoio para questões. (Ver anexo A).

\section{Análise documental}

A análise documental ajudou no processo de estudo do problema, através de documentos oficiais, teses de doutorado, dissertações de mestrado e mapas da região. 
Também foram utilizados documentos e estatísticas (minutas de reuniões, relatórios anuais, recortes de jornal) gerados pela comunidade. Segundo Becker (1994:122), "Eles podem propiciar um histórico útil, documentação necessária das condições de ação para um grupo (como num conjunto de regras codificadas) ou um registro conveniente de eventos e análises".

A análise dos documentos acima mencionados proporcionou uma aproximação com a realidade local e com a disposição física do distrito de Sousas e Joaquim Egídio, além de esclarecer o zoneamento da área, os principais problemas enfrentados pelos moradores, a intensa especulação imobiliária, dentre outros.

\section{Descrição das atividades:}

\section{Fazendo os primeiros contatos}

Inicialmente, logo que a idéia da pesquisa e a definição do local foram sendo delimitados, iniciou-se um primeiro contato com a diretoria da Escola Municipal de Ensino Fundamental "Professora Ângela Cury Zackia", localizada em Sousas, para que pudesse ser exposta a idéia de pesquisa e também para saber se havia interesse da Escola em participar da mesma. A pesquisadora explicitou a idéia inicial, salientando que a participação dos alunos seria fundamental para que a pesquisa acontecesse. Após ser dada resposta positiva por parte da Diretoria da Escola, que se demonstrou interessada em contribuir com elementos para a pesquisa, estabeleceu-se os primeiros contatos. Posteriormente a esse contato inicial com a diretoria, era necessário ainda ter a aceitação dos jovens alunos que cursavam a $7^{\mathrm{a}}$. (sétima série do ensino fundamental) acontecendo dessa forma o primeiro encontro com eles.

\section{Questionário}

A pesquisadora foi então apresentada aos alunos pela diretora da Escola deixando claro nesse momento sua intenção de pesquisa, ou seja, estudar o que 
eles entendiam sobre determinados assuntos ligados ao meio ambiente e houve uma breve exposição sobre o interesse de pesquisa.

Após isso foi iniciada a aplicação de questionários ressaltando-se que não se tratava de uma prova, e sim um primeiro contato que serviria como elemento norteador para todos os outros processos da pesquisa. Portanto, ficou claro que as respostas deveriam ser individuais e que não existiam questões certas ou erradas, somente opiniões.

Aplicou-se então o questionário para um grupo formado pelos 27 alunos da $7^{\mathrm{a}}$ série durante o período da aula de Ciências, na data de 20 de Junho de 2001. A duração da aplicação do questionário foi de aproximadamente 40 minutos.

Durante a aplicação do questionário, a pesquisadora se ausentou do local e voltou quando a grande maioria já havia terminado, agradeceu a atenção e saiu.

As crianças mostraram-se um pouco exaltadas e conversadeiras, situação esperada quando há algo diferente do que normalmente estão acostumadas.

Nesse primeiro contato, deixou-se avisado que seria feito um dia de campo com os alunos e todos se mostraram interessados em participar. A data seria marcada posteriormente à reflexão sobre os questionários aplicados inicialmente.

\section{Dia de campo}

Num segundo encontro, foi feito um convite aos alunos que haviam respondido o questionário, à professora de Ciências e a vice-diretora Lavínia, para que viessem participar de um dia de atividades na Fazenda Santa Maria localizado em Joaquim Egídio.

Marcou-se então o dia de campo para 15 de agosto de 2001 no horário das 8 h30 às $16 \mathrm{~h} 30$.

As atividades foram programadas com antecedência pela pesquisadora, buscando os objetivos traçados pela pesquisa tendo naquele dia além da mesma, 
mais três monitores ${ }^{1}$ que colaboraram para que cada uma das etapas programadas pudesse acontecer.

Havia 27 alunos com idades entre 12 a 15 anos.

Deu-se início à primeira atividade da visita.

\section{$1^{\mathrm{a}}$. atividade - "Procura-se"}

Separados em duplas, os alunos receberam uma folha que continha algumas questões e eles deveriam procurar dentre os amigos, quem soubesse responder as perguntas. Esta atividade além de proporcionar uma maior aproximação e troca de informações entre eles, foi também uma forma de instigálos a investigar os temas abordados. Dentre as questões contidas na folha tinham: o nome da Apa; os nomes dos rios de Campinas; o nome de algum animal brasileiro; o nome de alguma árvore brasileira; um animal em extinção; alguém que já tenha ido a cachoeira em Joaquim Egídio, que já tenha ido a alguma fazenda em Joaquim Egídio.

Esta atividade teve duração aproximadamente 20 minutos.

No final, percebeu-se que nem todos conseguiram responder todas as perguntas, principalmente aquelas relacionadas a Apa. Isto provocou a necessidade de se fazer uma mini palestra sobre a área em que aqueles alunos vivem, embora vivessem lá se mostraram totalmente alheios à sua importância ambiental.

\section{$2^{\mathrm{a}}$. atividade - Aprendendo sobre a Apa}

Esta segunda atividade foi pensada e elaborada com antecedência e só seria realizada dependendo da primeira atividade. Caso todos os alunos já tivessem um bom repertório sobre o local, não seria necessário fazê-la.

\footnotetext{
${ }^{1}$ Paulo André, Sussana Ulson e Vivian Gladys de Oliveira Souza
} 
Sentaram embaixo de uma grande árvore e foi iniciada uma mini palestra em que se esclareceu o que vem a ser uma Área de Proteção Ambiental, quais os atributos fazem daquela região um local especial, quais rios fazem parte da sua bacia hidrográfica e a importância histórica e cultural.

Usou-se nesta palestra, painéis antigos da sede, painéis sobre a Apa, mapas para que pudessem visualizar melhor o local. Logo após a explanação da pesquisadora foi aberto alguns minutos para que os alunos pudessem fazer perguntas. Esta atividade durou cerca de 15 minutos.

\section{$3^{\mathrm{a}}$. atividade - "Passeando pela Sede"}

Esta atividade proporcionou aos alunos viajar um pouco no tempo, logo no início do passeio foram levados a senzala, neste local há objetos que eram utilizados pelos escravos e fazendeiros daquela época (séc. XIX). As paredes de pau-a-pique puderam dar uma noção de como eram feitas as construções antigamente, a visita ao oratório também foi interessante para entenderem nossas antigas tradições religiosas.

Esta atividade durou cerca de 20 a 30 minutos. A composição da história local é interessante para que possam compreender um pouco mais os dias atuais, compor um cenário a partir da construção histórica do local.

\section{$4^{\mathrm{a}}$. atividade "Três coisas para o futuro"}

A quarta atividade "Três coisas para o futuro", relata-se uma estória de que o mundo vai acabar e cada um só poderá levar três coisas/objetos que desejaram, mas que deverão refletir muito bem sobre o que irão levar para que a escolha valha a pena.

Esta atividade fornece para a pesquisa um olhar dos alunos para aquilo que realmente tem importância em suas vidas, o que realmente os interessa. 
Distribuíram-se cartolinas na forma de nave espacial que simularia a nave espacial com a qual conseguiriam deixar a Terra em direção a outro planeta antes que ela fosse destruída.

Esta atividade teve duração de cerca de 40 minutos.

\section{$5^{\mathrm{a}}$. atividade - "Muro das lamentações e árvore dos sonhos"}

Foi elaborado um grande painel que simulava o Muro das lamentações ${ }^{2}$. Neste muro os alunos deveriam pregar desenhos ou palavras que representasse tudo aquilo que os aflige em suas vidas cotidianas e mesmo no mundo. Esta atividade proporcionou que fosse explicitado tudo aquilo, ou quase tudo, que os incomoda e muitos temas foram levantados como: violência, falta de oportunidades e emprego, questões ligadas a sobrevivência, questões ambientais, dentre outros.

Cada um dos participantes dirigia-se ao muro e pregava a figura ou a palavra que representava sua aflição.

Após esta fase, foram organizadas as principais queixas apresentadas por eles e cada um explicava o porquê de tê-la escolhido. Muitos assuntos se repetiram entre eles.

Após todos observarem os principais temas elencados como ruins ou aflitivos, passou-se para a etapa seguinte desta mesma atividade, "A Árvore da Esperança", esta atividade proporcionou aos alunos a exposição dos seus desejos e sonhos para o futuro. Para esta atividade foram disponibilizados papéis, canetinhas, lápis de cor e a expressão poderia ser feita através de desenhos ou palavras que representassem seus desejos. A reflexão sobre um futuro melhor e a visualização dos desejos individuais e coletivos indica que é preciso estar ativo e atento para que esses desejos sejam alcançados.

A duração da atividade foi de aproximadamente 50 minutos.

\footnotetext{
${ }^{2}$ Muro das Lamentações - Muro localizado em Jerusalém (Israel) que circunda a cidade antiga e é considerado uma das valiosas edificações que vem sobrevivendo ao passar dos séculos e é o local mais importante no mundo para a religião judaica. São escritas as aflições e amarguras, mas também os desejos e sonhos e depositados nos vãos do muro.
} 


\section{$6^{\text {a }}$. atividade - "Tempestade cerebral"}

Nesta atividade os alunos eram divididos em duplas e cada um fazia uma pergunta ao outro, quem não tivesse perguntando estaria anotando a resposta. As respostas deveriam ser instantâneas. Depois se invertia o jogo. Houve certo embaraço na primeira tentativa, mas logo em seguida todos compreenderam as regras e se divertiram. A pergunta era: "Eu te falo: . E o que vem a sua cabeça?" E na seqüência, outra pergunta "Por que?". Os temas questionados foram: Ambiente, Minha casa, Apa e Água.

\section{$7^{\mathrm{a}}$. atividade - "Tinha um rio"}

O grupo foi dividido em dois subgrupos, cada aluno do subgrupo deu as mãos para o colega ao lado perfazendo um círculo. Em seguida iniciou-se com a frase: "Tinha um rio..." e o colega ao lado deveria completar a frase. Todos deveriam falar ao menos uma frase e a atividade acabaria quando se esgotassem as frases. Os dois grupos se remeteram a poluição do rio Atibaia, a uma visão pessimista, de uma realidade triste e sem perspectiva de mudança. 


\title{
5 MEIO AMBIENTE E EDUCAÇÃO
}

\subsection{Educação}

\author{
Partíamos que a posição normal do homem (...), \\ era a de não apenas estar no mundo, mas com ele. \\ De travar relações permanentes com este mundo, \\ que decorre pelos atos de criação e recriação (...). \\ E que, nestas relações com a realidade e na realidade, \\ trava o homem uma relação específica \\ - de sujeito para objeto - que resulta o conhecimento, \\ expressado pela linguagem.
}

Educar significa promover o processo de desenvolvimento da capacidade intelectual e moral do ser humano com o intuito de integrá-lo individual e socialmente no seu ambiente. Através da compreensão e organização de novas informações, construção de um conhecimento e, principalmente, da expressão da potencialidade individual, do entendimento da condição de sujeito ativo e participativo dentro da construção desse conhecimento. É um processo permanente, que acontece durante toda a vida.

O parágrafo a seguir foi elaborado a partir de reflexões realizadas pela leitura do livro: "Educação, um tesouro a descobrir", do autor Jacques Delors (1999). O capítulo "Os quatro pilares da educação", desse livro, apresenta uma interessante discussão sobre o papel da educação e destaca a importância dela transmitir de maneira eficaz, "saberes e saber-fazer evolutivos, adaptados a civilização cognitiva, pois são as bases das competências do futuro". A educação deve se centrar em alguns alicerces, que servirão de "pilares do conhecimento" e são eles: "aprender a conhecer: onde cada um compreenda o mundo que o 
rodeia, para desenvolver suas capacidades profissionais, para se comunicar. Exercitando a atenção, a memória, e o pensamento (...) e o exercício da memória entendido aqui como "antídoto necessário contra a submersão pelas informações instantâneas difundidas pelos meios de comunicação social; aprender a fazer: para poder agir sobre o meio envolvente, desenvolver a competência para ser apto a enfrentar as numerosas situações e a trabalhar em equipe; aprender a viver juntos: a fim de participar e cooperar com os outros em todas as atividades humanas, tomar consciência das semelhanças e da interdependência entre todos os seres humanos do planeta; e finalmente aprender a ser: onde a educação deve contribuir para o desenvolvimento total da pessoa, espírito e corpo, inteligência, sensibilidade, sentido estético, responsabilidade pessoal, espiritualidade (...), para elaborar pensamentos autônomos e críticos e formular os seus próprios juízos de valor, de modo a poder decidir, por si mesmo, como agir nas diferentes circunstâncias da vida".

Fica claro, nesse texto, que a educação é um longo processo que tem início no universo familiar, seguido depois, sempre que possível, na escola, e continuando durante toda a vida. Em se tratando do aprendizado durante a vida, é importante ressaltar que a cultura é aprendida no cotidiano e não somente no âmbito do universo escolar. Age como "ferramenta conceitual para lidar com as coisas, tomar decisões, resolver problemas. (...)". Ampliando os "esquemas mentais de compreensão da realidade, pois a pessoa pode, assim, captar as realidades econômicas, sociais e culturais do mundo atual, interpretar um mundo cada vez mais complexo e agir eficazmente nas situações de sua vida cotidiana". (Libâneo, 2000).

$\mathrm{Na}$ escola, os objetos do conhecimento, ou os assuntos das aulas, também chamados de conteúdos são "os conhecimentos sistematizados, selecionados das bases das ciências e dos modos de ação acumulados pela experiência social da humanidade e organizados para serem ensinados na escola; são habilidades e hábitos (o saber fazer), vinculados aos conhecimentos (conceitos, teorias, informação, o saber sistematizado), incluindo métodos e procedimentos de 
aprendizagem e de estudo; são atitudes, convicções, valores (o saber agir), envolvendo modos de agir, de sentir e de enfrentar o mundo" (Libâneo, 1980).

Krasilchik, (1986:1960), ao discutir sobre a EA adverte: "os assuntos devem ser tratados por um enfoque holístico, global e integrado considerando os vários ângulos e implicações de um mesmo problema. Aos fatores biológicos, físicos e químicos é preciso agregar os aspectos sócio-econômicos, políticos e culturais, sob pena de inutilizar todo o trabalho e ainda transmitir aos jovens uma visão incompleta e mutilada do processo". Mas isso deve ocorrer não somente na Educação Ambiental, e sim na educação como um todo.

Freire (1995) discute o processo educativo, inserido no contexto históricocultural, observando a importância da participação do educando na ação, afinal, são eles que fazem o mundo, como também, as suas mudanças.

"Homens e mulheres inventaram a história que eles e elas criam e fazem. E é exatamente a história e a cultura que homens e mulheres criam e fazem, a cultura alongando-se sobre a história, a história voltando-se sobre a cultura, que gera a necessidade de educar. A educação nasce na relação entre a cultura e a história, dentro da cultura e da história. Por isso não se faz educação dentro da cabeça de ninguém; se faz educação no contexto histórico, no contexto cultural. É por isso também que ela não pode ser neutra; não há, nunca houve, nem vai haver neutralidade educacional. Uma das conseqüências da invenção da existência foi a impossibilidade da neutralidade na criação. A invenção da existência deu-nos a possibilidade de estarmos não apenas no mundo, mas com o mundo. Eu posso mudar o mundo e é fazendo isso que me refaço é mudando o mundo que eu me transformo também." (FREIRE, 1995)

À educação cabe também a função de gerar espaços para as possíveis mudanças sociais, culturais, ambientais, políticas, econômicas, etc. Nessas 
circunstâncias, é um dos instrumentos chave para o progresso e desenvolvimento.

Brandão (1995) comenta que a educação ocorre "entre sujeitos igualados pelo trabalho comum e o saber comunitário", (...) e pertence do mesmo modo a todos e, se existe diferente para alguém, é para especializar, para uso de todos, portanto, ela atribui compromissos entre as pessoas". Há uma relação de troca, de pertencimento, muito discutida na EA, e que se inclui nas demais formas de aprendizagem.

Libâneo (1998) reforça a idéia de que o aluno tem que compreender a si próprio como ser pensante.

"O que está em questão é uma formação que ajude o aluno a se transformar num sujeito pensante, de modo que aprenda a utilizar seu potencial de pensamento por meio de meios cognitivos de construção e reconstrução de conceitos, habilidades, atitudes, valores. Trata-se de investir na combinação bem-sucedida da assimilação consciente e ativa desses conteúdos com o desenvolvimento de capacidades cognitivas e afetivas pelos alunos visando à formação de estruturas próprias de pensamento. (Libâneo,1998)".

A escola tem função de promover a educação e as aulas podem servir como ferramenta para tanto é necessário "criar um ambiente de aprendizagem na classe, onde o aluno possa reconstruir experimentos ou até mesmo conceitos". Portanto o aluno "só aprende se ler, pesquisar, elaborar". Pois, o ato de aprender consiste em "estar completamente envolvido, estar presente - não ser um objeto da fala do outro, das idéias do outro" (Demo, 2000).

Portanto, a escola é uma ferramenta potencial do aprendizado, em que o aluno deve ser instigado a participar do processo de forma ativa para se estabelecer o entendimento real do seu poder de cidadão. 
Para a Educação Ambiental, a escola pode ser o espaço para dialogar com a comunidade as questões ambientais vividas e vivenciadas. Abrindo a oportunidade para novas discussões, avaliações e críticas envolvendo a participação dos docentes, alunos e comunidade, rompendo seus muros e atendendo as reivindicações da rua, do bairro, da cidade, do país.

Ceccon (1990) afirma que o estudante "aprende na medida em que vai entendendo como funciona a sociedade e vai desmontando, pouco a pouco, essa engrenagem complicada da qual a escola é apenas uma peça". O aprendizado da sociedade e do ambiente se configura com interações. Só se entende a sociedade se houver uma busca do entendimento dela com o universo. Por mais distante, subjetivo ou isolado que possam aparentar os componentes do universo, como planetas, satélites e constelações, há uma intensa relação de dependência entre eles. A escola deve ser o meio pelo qual os indivíduos obtêm os instrumentos, fundamentados no conhecimento para desmontar e montar "essa engrenagem".

Benevides (1991) reafirma que o papel da escolarização formal é o de "equipar o cidadão para conseguir analisar o crescente volume de informações e de exigir e atuar nas decisões próprias da expansão das formas democráticas de vida, não garantindo sua adesão substantiva a elas".

Deste modo, a educação deve estar ancorada em vários "tipos" de aprendizado "porque a educação existe de mais modos do que se pensa e, aqui mesmo, alguns deles podem servir ao trabalho de construir um outro tipo de mundo". (Brandão, 1995)

Em se tratando de educação ambiental, fundamental para os compromissos da cidadania, é necessário “(...) despertar o potencial de cada individuo e da formação de valores e atitudes de co-responsabilidade, solidariedade, ética, negociação, gestão de conflitos ( ...) " (Sabia, 1998), pois somente assim estaremos realmente buscando as opiniões, posicionamento e críticas dos alunos. Um verdadeiro cidadão tem a capacidade de refletir e atuar tanto em nível local quanto global participa dos processos decisórios das dimensões técnicas, sociais e éticas, tem noção do seu valor na sociedade. Age 
além das necessidades imediatas, ultrapassa o círculo fechado das esferas familiar, local, do cotidiano. Opera na "gestão da realidade sócio-ambiental de modo comprometido com a vida, com o bem estar de cada um e da sociedade que integram".

\subsection{Educação Ambiental}

"Temam e tremam em vossa presença todos os animais da terra, todas as aves do céu, e tudo o que tem vida e movimento na terra. Em vossas mãos pus todos os peixes do mar. Sustentai-vos de tudo o que tem vida e movimento."

(GENESIS IX, 2-3)

"O pequeno recorte de um trecho da Bíblia Sagrada, o livro mais importante para a segunda religião em maior número de fiéis, retrata bem a concepção de mundo vigente durante muitos e muitos anos, a idéia de exploração sem limites, de recursos infindáveis, e o do poder do homem acima de tudo, incluindo a natureza. O homem se considerava o centro do universo e a razão da existência da Terra, tudo o que existia (entendendo aqui exatamente tudo) havia sido concebido por Deus para seu usufruto, para tornar sua vida mais agradável, bela, interessante. E, esse foi o pensamento que reinou e durante muitos séculos e séculos."

KEITH THOMAS

A questão ambiental, dentro do universo da sociedade humana nesse início de milênio, se depara com os novos caminhos possíveis de serem trilhados em meio a antiga estrutura de desenvolvimento econômico. Tais caminhos almejam o tão sonhado desenvolvimento sustentável, a justiça social, a ética em todos os segmentos inclusive na política, na administração pública e na responsabilidade social individual.

A educação ambiental pode proporcionar integração entre diferentes saberes, através das suas "várias portas para apreensão de significados e conhecimentos", segundo Segura (1999), motivando uma postura participativa, integrando os diferentes componentes da sociedade. 
A sociedade moderna e a inconcebível diferença entre os mais ricos e os mais pobres tem enraizado no seu interior o desequilíbrio sócio-ambiental visualizado nas absurdas desigualdades econômicas. O desenvolvimento econômico e tecnológico engrandeceu a capacidade humana de dominar os bens de produção e banalizou os meios de se atingir tal meta, a do enriquecimento a qualquer custo, desprezando todos os danos, perdas e prejuízos sociais para que isso seja obtido.

A orientação contida no documento denominado "Carta de Belgrado", propõe que a educação ambiental deva ser: "contínua, multidisciplinar, integrada às diferenças regionais, e voltada para os interesses nacionais". No relatório do encontro internacional do ano de 1977, promovido pela UNESCO e realizado em Tbilisi (Geórgia), fica evidenciada a "importância de se encarar os recursos do mundo como patrimônio de toda humanidade, patrimônio que deve ser utilizado de forma comunitária e solidária para possibilitar a melhoria da qualidade de vida de cada cidadão, e não somente de uns poucos mais abastados".

A educação ambiental é reconhecidamente um elemento crítico para o combate à crise contemporânea. Ainda, segundo a "Carta de Belgrado", é necessário promover uma nova ética no mundo, repensando atitudes e comportamentos (individuais e coletivos) mais harmônicos com a condição do ser humano na Terra, respeitando e também se responsabilizando pelas relações existentes entre o ser humano e a natureza e entre os próprios seres humanos. Mudanças são imprescindíveis, para se distribuir igualmente os recursos e conseguir atender mais as necessidades dos habitantes da Terra.

Pode-se considerar alguns dos princípios do Tratado de Educação Ambiental para Sociedades Sustentáveis e Responsabilidade Global para dialogar com premissas da Educação Ambiental.

a). A E.A. deve ter como base o pensamento crítico e inovador, em todos os lugares, épocas, modos formais ou não, promovendo a transformação e a construção da sociedade. É ideológica, política, baseado em valores para a transformação social. É individual e coletiva e tem o propósito de formar cidadãos 
com consciência local e planetária, que respeitem a autodeterminação dos povos e a soberania das nações. deve envolver uma perspectiva holística, enfocando a relação entre o ser humano, a natureza e o universo de forma interdisciplinar.

b). Estimular a solidariedade, a igualdade e o respeito aos direitos humanos, valendo-se de estratégias democráticas e interação entre as culturas. Recuperar, reconhecer, respeitar, refletir e valorizar a diversidade cultural entre os povos; potencializar o poder das diversas populações, retomando a condução de seus próprios destinos.

c). Tratar as questões globais críticas (suas causas e inter-relações), sob uma perspectiva sistêmica, em seus contextos social e histórico. Aspectos primordiais relacionados ao desenvolvimento e ao meio ambiente tais como população, saúde, democracia, fome, degradação da flora e fauna devem ser abordados dessa maneira.

d). Facilitar a cooperação mútua e eqüitativa nos processos de decisão, em todos os níveis e etapas, promovendo a cooperação e o diálogo entre indivíduos e instituições, com a finalidade de criar novos modos de vida, baseados em atender às necessidades básicas de todos, sem distinções étnicas, físicas, de gênero, idade, religião, classe ou mentais.

e). Integrar conhecimentos, aptidões, valores, atitudes e ações, convertendo cada oportunidade em experiências educativas de sociedades sustentáveis, valorizando as diferentes formas de conhecimento. Democratizar os meios de comunicação promovendo intercâmbio de experiências, métodos e valores. disseminando informações em bases igualitárias. 
Outro trecho importante da carta de Belgrado é o seguinte:

"Nossa geração tem assistido a um crescimento e progresso tecnológico jamais observados, que trazem benefícios a muitas pessoas e ao mesmo tempo vem causando graves conseqüências sociais e ambientais. (...) É absolutamente vital que os cidadãos do mundo insistam em medidas que apóiem um tipo de crescimento econômico que não tenha repercussões prejudiciais as pessoas, para o seu ambiente e suas condições de vida. É necessário encontrar maneiras de assegurar que nenhuma nação cresça ou se desenvolva as custas de outra e que o consumo feito por um individuo não ocorra em detrimento dos demais. Os recursos do mundo devem ser desenvolvidos de modo a beneficiar toda a humanidade e proporcionar a melhoria da qualidade de vida de todos. Nada mais necessitamos do que uma ética global. (...) $A$ reforma dos processos e sistemas educacionais é decisiva para a elaboração desta nova ética de desenvolvimento e orcem econômica mundial. Governos e formuladores de políticas podem ordenar mudanças e novas abordagens para o desenvolvimento, podem começar a melhorar as condições de convívio no mundo, mas tudo isso não passa de soluções de curto prazo, a menos que a juventude mundial receba um novo tipo de educação. Esta implicará um novo e produtivo relacionamento entre estudantes e professores, entre escolas e comunidades, e entre o sistema educacional e a sociedade em geral." (SECRETARIA DO MEIO AMBIENTE, 1994).

Concluindo o que se espera com a EA é promover a busca da cidadania, através do envolvimento, do conhecimento e da integração com a sociedade.

Brandão (1995) explicita que uma das vocações da educação é justamente a EA, inspirada nos valores de respeito às formas de vida e de solidariedade, como a necessidade de adquirir conhecimentos ambientais específicos, para 
compreender a interdependência dos elementos da cadeia de sustentação da vida.

A participação é elemento fundamental para realização da EA. Reigota (1994) concorda e afirma que é uma educação política que tem como objetivo não somente o uso racional dos recursos, mas a participação do cidadão nas decisões que Ihe diz respeito. Benevides (1996) resume essa idéia em um pensamento "(...) Sem a participação dos interessados no estabelecimento de metas e em sua execução, (...) não existe a possibilidade de bem comum (...)".

As comunidades, além de colaborarem na proteção do meio ambiente, devem também tomar decisões sobre os problemas relativos à sua interação como ele, para se manterem as condições adequadas de vida (Krasilchik, 1986). Decorre dai a importância de programas de educação ambiental, que propiciem o aumento do conhecimento, mudança de valores e o aperfeiçoamento de habilidades, que são condições básicas para que o ser humano assuma atitudes e comportamentos que estejam em sintonia com o meio.

A noção de pertencimento é o laço entre o indivíduo e a coletividade. Também chamado de compromisso (Freire, 1979), que só existe no engajamento com a realidade, de cujas "águas" os homens verdadeiramente comprometidos ficam "molhados", ensopados. Somente assim o compromisso é verdadeiro. Enfim entender que o homem é parte do todo, que deve interagir com o meio, ativamente e intensamente. "Não é possível um compromisso autêntico se, aquele que se julga comprometido, a realidade se apresenta como algo dado, estático e imutável. Se este olha e percebe a realidade enclausurada em departamentos estanques" (Freire,1979).

\subsection{Incertezas}

"O planeta Terra vive um período de intensas transformações técnicocientíficas, em contrapartida das quais engedram-se fenômenos de desequilíbrios ecológicos que, se não forem remediados, no limite, ameaçam a implantação da vida em sua superfície. Paralelamente a tais perturbações, os modos de vida humanos individuais e coletivos 
evoluem no sentido de uma progressiva deterioração. As redes de parentesco tendem a se reduzir ao mínimo, a vida doméstica vem sendo gangrenada pelo consumo da mídia, a vida conjugal e familiar se encontra freqüentemente "ossificada" por uma espécie de padronização dos comportamentos, as relações de vizinhança estão geralmente reduzidas a sua mais pobre expressão..."

Félix Guattari

Uma das possíveis causas do desenraizamento, talvez inconsciente, sofrido pelas gerações atuais pode ser atribuído provavelmente, pela dúvida em relação ao futuro do planeta, todavia não exclusivamente. Dúvida essa causada pela desconfiança gerada por fatores da vida contemporânea, entre eles: a expansão da criminalidade e do terrorismo, o aumento da violência em todas as classes sociais, grupos e categorias, a escalada armamentista, a deterioração do meio ambiente, a desigualdade econômica assustadora entre os países, ocasionando uma sensação de mal estar, porém ao mesmo tempo de impotência, pela perspectiva e especulação de um prolongado declínio econômico, pela ausência de empregos e oportunidades, entre outras. Toda essa dinâmica confusa da realidade mundial não estimula as pessoas a viver o presente sem temer o futuro.

Segundo Lasch (1986), isso nos faz "passarmos a nos preparar para o pior, às vezes, construindo abrigos anti-radiativos e armazenando provisões, outras vezes, o que é mais comum, executando uma espécie de recuo emocional frente aos compromissos a longo prazo, que pressupõe um mundo estável, ordeiro e seguro. O risco de desintegração individual estimula um sentido de individualidade que não é "soberano" ou "narcisista", mas simplesmente sitiado". É essa a idéia de estado de sítio a que se refere o desenraizamento, ou a desterritorialidade.

Arendt (1994) cita Kant (1945) ao mencionar que "será sempre desconcertante... que as gerações precedentes pareçam carregar seu fardo de ocupações apenas para o bem das que virão... e que apenas as últimas devam ter a sorte de habitar a construção (completa)". Ou seja, teremos sempre que 
construir para um futuro distante pois nunca veremos a obra terminada e muito menos teremos o usufruto dessa obra.

Esse ser "desintegrado" se sente impotente e desconfiante, tem dificuldade em compreender a história, e também em transformá-la. Torna-se passivo, expectador e voyerista, característica dos sobreviventes. "Nós aprendemos a ficar fora de nossa história e a observa-la, sem sentir muita coisa" (Lasch, 1986). Não tem nem interesse nem vontade de participar de qualquer atividade coletiva.

Serres (1991) apresenta a sobrevivência do planeta e a dependência de um futuro mais digno ou não, diretamente ligado a assinatura de um "contrato natural" entre o homem e seu meio. E ressalta que nesse contrato o mundo natural é considerado como "um bem nosso, nem privado nem comum, mas de agora em diante simbiota".

Serres (1991) ainda discute um "enraizamento paradoxal no global: não em uma terra, mas na Terra, não no grupo, mas em toda parte" e em uma metáfora conclui "a imagem da planta quase não tem mais sentido. Depois que decolamos, em uma possante e longínqua nave, contamos mais com laços imateriais do que com raízes. Seria este o fim dos arraigamentos?" Permanece o questionamento. Será o fim das raízes, será que já rompemos com esse elo?

É dentro desse contexto que a $\mathrm{E}$. A. a que se refere esta dissertação pretende discutir, a incerteza e a perda do elo de ligação entre o meio e o ser humano, ou seja, seus laços de pertencimento.

\subsection{0 sentimento de pertencimento}

Para se proteger do perigo, sós e fechados como certos crustáceos, os guerreiros da Idade Média e da Antiguidade se envolviam com couraças esmagadoras; com a guerra, a natureza preferiu mais tarde a estratégia flexível da carne mole por fora e o esqueleto duro por dentro; uma terceira solução, ainda mais evoluída, consiste em colocar suas defesas e sua segurança por fora do corpo: nas relações. O que sai, pende ou perde de mim e me salva, eu aparelho para a corda. Embora não tenhamos nenhuma prova disso, esta ligação teria constituído a primeira invenção 
da técnica humana: a contemporânea do primeiro contrato. Em um meio mole, enquanto o ambiente permanece despojado, ninguém sente a necessidade de laços e todos perambulam sós, à vontade; mas eis que ele ganha relevo e se torna duro; o coletivo então se une pela corda e se refugia no contrato social.

Michel Serres

Tuan (1980) em seu livro sobre topofilia (do grego topo significa lugar e phil gostar) relata que o que falta às pessoas na sociedade atual é o envolvimento suave e inconsciente para com o lugar onde habita, como havia no passado, quando o ritmo de vida era mais lento. Pode ser considerado um "patriotismo local", um sentimento "construído através da experiência íntima com o lugar, o que fortalece os vínculos com o espaço, transformando-o em território".

O sentimento de pertencimento ocorre de várias formas diferentes, mas segundo Tuan (1980), desenvolve-se em relação a uma pequena localidade, a qual os moradores sentem possuir algum controle, e se identifica com ele, sente-o como seu lar e de seus antepassados.

Morin (1994) descreve perfeitamente esse pensamento ao explicitar que o homem, por um lado, tem a sua natureza biológica, física e cósmica e por outro, a cultural, ou seja, do universo da palavra, do mito, da idéia, da razão e da consciência. E é a partir dessas identidades "propriamente humanas", a família, a ética, a religiosa, a social e a nacional que o enraíza na terra.

O laço de pertencimento realmente ocorre quando o cidadão se reconhece como parte integrante de seu meio, participando e interagindo nas atividades diárias e cívicas da sua comunidade. É o sentir-se pessoalmente responsável e proprietário de tudo o que constitui seu habitat, considerado como sua casa rua, praças, parques e jardins, vias públicas, as construções e edificações, os monumentos, os meios de transportes, as áreas especiais de proteção aos recursos naturais. É um sentimento que ultrapassa o respeito, e busca a conservação, preservação ou manutenção, uso e discussão a respeito do futuro e do seu ambiente. 
É interessante analisar a descrição técnica de Serres (1991) sobre laços:

"A descrição técnica dos laços e de seus nós permite-nos manter juntos o espaço contínuo e seu limite catastrófico, a tipologia do flexível e a geometria da corda esticada, que sozinha pode medir ou partilhar, distribuir ou atribuir, a variação e a invariância, portanto, juntas as restrições e a liberdade. É como se víssemos nascer, ao mesmo tempo, as ciências, as técnicas e o direito. (...) Além disso, gosto de dizer que o laço compreende, pois ele junta e aperta ou prende inúmeras coisas, animais ou homens em conjunto. Eis, sem dúvida, o primeiro semi-objeto próprio a tornar aparente e concretas nossas relações: as correntes reais da obrigação, leves aqui, pesamnos lá. (...) O laço percorre todos os lugares mas, além do mais, expressa em todos os pontos a totalidade dos locais; é certo que ele vai do local ao local, mas sobretudo do local ao global e do global ao local".

O sentimento de pertencimento também é despertado quando se fala a respeito de uma entidade planetária da qual todos nós pertencemos. Morin (1994) idealiza esse lugar chamando-o de "Terra-Pátria", como a nossa casa, nossa mátria, local do nosso enraizamento no cosmos e acrescenta "É aqui, em nossa casa, que estão as nossas plantas, os nossos animais, os nossos mortos, as nossas vidas e os nossos filhos. Temos de conservar, temos de salvar a TerraPátria".

Em 2002, Morin, (2002) repete "se o planeta constitui um território que dispõe de um sistema de comunicação, de uma economia, de uma civilização e uma cultura, também é fato que Ihe falta um certo número de dispositivos essenciais, que são a governança, a cidadania, o controle dos poderes, sem falar na consciência comum de fazer parte da Terra-Pátria", e relata os mesmo problemas antigos, a falta de uma "consciência planetária" ou da "entidade planetária". 
Noleto (2001) alerta para a ausência do "pertencimento cidadão": desencanto com os aparatos institucionais, discriminação, exclusões políticoeconômico-sociais e perda de referencial ético valorativo coletivo, assim como baixa auto-estima, com propensão a se enredar em violências, drogas e vandalismo.

Weil (1979) define o enraizamento como:

"O enraizamento é talvez a necessidade mais importante e mais desconhecida da alma humana. É uma das mais difíceis de definir. O ser humano tem uma raiz por sua participação real, ativa e natural na existência de uma coletividade que conserva vivos certos tesouros do passado e certos pressentimentos do futuro. Participação natural, isto é, que vem automaticamente do lugar, do nascimento, da profissão, do ambiente. Cada ser humano precisa ter múltiplas raízes. Precisa receber quase que a totalidade de sua vida moral, intelectual, espiritual, por intermédio dos meios de que faz parte naturalmente".

Etimologicamente território significa terra pertencente a alguém. Portanto, um local somente se transforma em território quando há o laço de pertencimento entre o lugar habitado e os moradores.

Para Santos (1994) a nova realidade do território é a "interdependência universal dos lugares" evoluído da "antiga comunhão individual dos lugares com o Universo à comunhão hoje global". Segundo o mesmo autor, não há mais lugares isolados no globo, todos estão sucumbidos à globalização.

E o processo inverso, segundo lanni (1992), a "desterritorialização, é o produto da globalização, que tende a desenraizar as coisas, as gentes, as idéias, (...), aplica-se também a grupos éticos, lealdades ideológicas e movimentos políticos que atuam crescentemente em moldes que transferem fronteiras e 
identidades territoriais específicas (...) manifesta-se tanto na esfera da economia como da política e da cultura".

Weil (1979) considera desenraizamento "a mais perigosa doença das sociedades humanas, porque se multiplica a si própria". Os seres atingidos por esse mal têm dois destinos: ou morrem ou lutam desbravadamente para desenraizar os outros. Também há o "desenraizamento que se poderia chamar geográfico, ou seja, em relação às coletividades que correspondem a territórios. $O$ próprio sentido dessas coletividades quase desapareceu, exceto por uma única, a nação.(...)" (Weil, 2001).

Ab'saber (1994), ressalta que a Educação Ambiental "envolve todas as escalas. Começa em casa, atinge a rua e a praça, engloba o bairro, abrange a cidade ou a Metrópole, ultrapassa as periferias, repensa o destino dos bolsões de pobreza e diversidades regionais, para só, depois, penetrar na intimidade dos espaços ditos "opressores", atingir as peculiaridades e diversidades regionais, para só, depois, integrar, em mosaico, os espaços nacionais e, assim, colaborar com os diferentes níveis de sanidade exigidos pela escala planetária, dum fragmento de astro que asilou a vida e deu origem aos atributos básicos do ser que pensou o Universo."

Sorrentino (1998:37) resume a tendência dos trabalhos de educação ambiental em: "a) instigar o indivíduo a analisar e participar na resolução dos problemas ambientais da coletividade; b) estimular uma visão global e critica das questões ambientais; c) promover um enfoque interdisciplinar que resgate e construa saberes; d) possibilitar um conhecimento interativo através do intercambio de pontos de vista e e) propiciar um auto-conhecimento que contribua para o desenvolvimento de valores (espirituais e materiais), atitudes, comportamentos e habilidades".

Seara Filho (1986), comenta o fato de que a educação deve atingir o comportamento das pessoas, ser modificado a partir daquilo que aprendeu, não apenas pelo ouvir e pelo falar, mas também pelo exemplo e pela identificação das situações concretas. Não é um produto e sim um processo permanente, que ao 
invés de ensinar alguém o que pensar ou fazer, procura despertar neste o como pensar e agir.

Do ponto de vista da educação, preparar o indivíduo significa torná-lo cada vez mais capaz de conhecer os elementos de sua situação para intervir nela, transformando-o no sentido de uma ampliação de liberdade da comunicação e da colaboração entre os homens (Saviani, 1982). O que se observa na literatura é que a maioria dos programas de educação ambiental, segundo Santos (1998), é pontual sendo que o mais adequado seria que tivessem continuidade.

A Educação Ambiental, juntamente com instrumentos legais, licenciamentos, planejamentos ambientais, tecnologias "limpas", estudos de impactos ambientais, e etc, alavanca o processo de construção de uma nova sociedade, baseada por princípios mais solidários e sustentáveis do que os utilizados no passado.

\subsection{Percepção}

"E que é o diálogo? É uma relação horizontal de A com B. Nasce de uma matriz crítica e gera criticidade. Nutre-se de amor, da humildade, de esperança, da fé, da confiança. Por isso, só o diálogo comunica. E quando os dois pólos do diálogo se ligam assim, com amor, com esperança, com fé um no outro, se fazem críticos na busca de algo. Instala-se, então, uma relação de simpatia entre ambos. Só aí há comunicação".

Paulo Freire

A percepção é um processo mental de interação do indivíduo com o meio ambiente que se dá através de mecanismos perceptivos propriamente ditos e, principalmente cognitivos. Os primeiros são dirigidos pelos estímulos externos, captados através dos 5 sentidos. Os segundos são aqueles que compreendem, a contribuição da inteligência, admitindo-se que a mente não funciona apenas a partir dos sentidos e nem recebe essas sensações passivamente (Del Rio,1996).

Tuan (1980) ressalta que a percepção varia de acordo com o que tem valor para nós, para nossa sobrevivência biológica e para proporcionar certas 
satisfações que estão enraizadas em nossa cultura. A atitude é uma postura individual frente ao mundo e tem mais estabilidade do que a percepção pois é formada por uma grande sucessão de percepções, experiências. O nosso olhar para o mundo é em grande parte social.

Cada um de nós percebe, reage e responde de forma diferente frente às ações sobre o meio. Segundo Ferrara (1996), essas respostas são resultado das percepções, dos processos cognitivos, julgamentos e expectativas de cada indivíduo. Embora nem todas as manifestações psicológicas sejam evidentes, são constantes, e afetam nossa conduta, na maioria das vezes, inconscientemente.

Com certeza, existem diversas maneiras de se ver o mundo e cada imagem e idéia a respeito do mundo são estabelecidas a partir da experiência pessoal, do aprendizado, da imaginação e da memória. Todas as experiências, desde as mais ligadas ao cotidiano do ser humano, ou as mais distanciadas do mundo diário, compõe o quadro individual da realidade. "A superfície da Terra é elaborada para cada pessoa pela refração por meio de lentes culturais e pessoais, de costumes e fantasias" (Machado 1996: 97).

Nosso universo individual de percepção varia de acordo com esse conjunto de experiências vivenciado, experimentado, observado, praticado. Cada um de nós cria e organiza sua realidade, de acordo com a própria percepção e desejo. (Leripio, 2000).

Através da percepção ambiental são estabelecidas as relações de afetividade do indivíduo para com o ambiente. Leff (2001:21) situa a percepção ambiental a partir do contexto vivido. "Na história humana, todo saber, todo conhecimento sobre o mundo e sobre as coisas tem estado condicionado pelo contexto geográfico, ecológico e cultural em que produz e se reproduz determinada formação social." 


\subsection{Cidadania, coletividade e participação.}

“(.) Esse acoplamento produz a reflexividade que permite o ato de mirar a partir de uma perspectiva mais abrangente, o ato de sair do que até este momento era invisível ou intransponível para ver que, como seres humanos só temos o mundo que criamos com outros. A esse ato de ampliar nosso domínio cognitivo reflexivo, que sempre implica em uma experiência nova, só podemos chegar pelo raciocínio motivado pelo encontro com o outro, pela possibilidade de olhar o outro como um igual, num ato que habitualmente chamamos de amor - ou, se não quisermos usar uma palavra tão forte, a aceitação do outro ao nosso lado na convivência. Esse é o fundamento biológico do fenômeno social: sem amor, sem a aceitação do outro ao nosso lado, não há socialização, e sem socialização não há humanidade. Tudo o que limite à aceitação do outro - seja a competição, a posse da verdade ou a certeza ideológica - destrói ou restringe a ocorrência do fenômeno social e, portanto, também o humano, porque destrói o processo biológico que o gera. Não se trata de moralizar - não estamos pregando o amor, mas apenas destacando o fato de que biologicamente, sem amor, sem a aceitação do outro, não há fenômeno social. Se ainda se convive assim, é hipocritamente, na indiferença ou na ativa negação"

Maturana, H.; Varela, F.G.

Entende-se por cidadania o fato de todos nós pertencermos a um agrupamento humano e nele, convivermos com outras pessoas com os mesmos direitos e deveres, de preferência resultantes de acordos coletivos, onde todos os componentes da comunidade ajudaram a construir, opinaram, participaram. Temse sempre em vista algum tipo de vida que a todos possa parecer minimamente boa. Participar nas decisões é fundamental, pois as decisões deverão ser cumpridas por todos. 
Sposati (2001:34) considera alguns parâmetros interessantes para definir cidadania: "o reconhecimento de acesso a um conjunto de condições básicas para que a identidade de morador de um lugar se construa pela dignidade, solidariedade e não só pela propriedade". Esta dignidade não é somente o usufruto de um padrão básico de vida, mas sim a presença, interferência e decisão na esfera pública da vida coletiva.

Segundo Benevides, (1994:08) "Cidadania significa necessariamente o reconhecimento da igualdade e da liberdade dos cidadãos, pois o próprio conceito de cidadão é o do indivíduo portador de direitos e deveres". Tolerância, fraternidade e solidariedade também fazem parte do conjunto representado pela cidadania.

A educação para cidadania trabalha a criação de sujeitos políticos, antenados na consciência de seus deveres e direitos. Jacobi (1998) afirma a necessidade de "motivar e sensibilizar as pessoas para transformarem as diversas formas de participação, em potenciais caminhos de dinamização da sociedade e de concretização de uma proposta de sociabilidade baseada na educação para a participação". Sem participação não há autonomia, não se estabelecem identidades locais, ou como Santos (1997) denomina "identidades coletivas de vizinhança, de região, de raça, de etnia, de religião", o vínculo entre os indivíduos, seus territórios (simbólicos ou físicos) e o tempo.

É a partir da participação que se cria possibilidades de controle do conjunto da vida individual e coletiva incentivando a idéia de gerência da própria existência constituindo a partir daí, a noção de responsabilidade e compromisso. "Todos temos o direito de participação para decidir sobre aquilo que é de interesse comum, mas todos também temos o dever de participação, para que seja possível a supremacia, verdadeira, real e não apenas formal e aparente, da vontade do povo. Com essa participação, poderemos sim, não tenho nenhuma dúvida, conseguir mudanças muito profundas." (Dallari, 2001:114).

Em se tratando de participação, é interessante discutir sobre a passividade e a ação. Nas palavras de Sawaia (2001:125) "A participação como potência trata da passagem da passividade à atividade, da heteronomia passiva à autonomia 
corporal". A potência de ação está ligada à capacidade de ser afetado pelo outro, havendo a possibilidade desta capacidade ser constituída por paixões ativas, quando se relaciona a potência de ação e passivas quando se relaciona a potência de padecer.

Morin (2000) concorda com esse pensamento ao afirmar "todo desenvolvimento verdadeiramente humano significa o desenvolvimento conjunto das autonomias individuais, das participações comunitárias e do sentimento de pertencer à espécie humana".

Neste capítulo foi abordado um conjunto de referências sobre EA sem a pretensão de esgotar o assunto, mas que busca refletir sobre o estado da arte do tema. 


\section{RESULTADOS E DISCUSSÃO}

Neste capítulo serão apresentados os resultados e suas respectivas discussões buscando evidenciar características do grupo pesquisado.

Os resultados da pesquisa serão expostos e discutidos em grupos de grandes temas onde as atividades foram consideradas em conjunto havendo uma nota ao final de cada transcrição, para indicar de qual atividade foi retirado o depoimento. Tais depoimentos são fragmentos transcritos das entrevistas, trechos selecionados das oficinas, cópia de apresentações do dia de campo ou frases captadas no questionário. As transcrições estão escritas entre aspas e o nome da atividade entre parênteses. Nas transcrições da atividade "Tempestade cerebral" estão todas as respostas num único parágrafo, e nas transcrições da atividade "Muro das lamentações", cada frase equivale a resposta de um aluno. Em todos os outros exemplos cada parágrafo corresponde a uma resposta individual. Todas as respostas estão no anexo C.

Os grandes temas são: 6.1) Violência e sobrevivência; 6.2) Volta ao passado, Fuga para o futuro e Sonhos de um mundo melhor; 6.3) A questão ambiental. Esses temas emergiram conforme já foi relatado na metodologia.

\subsection{Violência e sobrevivência}

O grande sonho e a maior lamentação se referem à violência. A grande maioria das respostas dessas duas atividades (89\%) remete significativamente a uma perspectiva de fim da violência, retratada como assassinatos, falta de 
segurança, drogas, assaltos e falta de policiamento. Alguns exemplos podem ser apresentados nas frases abaixo:

"a violência, o desemprego, as mortes de pessoas inocentes, assalto nas ruas e as drogas." (Atividade: Muro das lamentações).

"mais escolas; mais lazer; o fim da violência; não ter mais criança na rua; mais amor" (Atividade: Árvore dos sonhos).

"que não tivesse violência, drogas, fome, abandono, morte, desemprego e que tivesse saúde, emprego, alimentação." (Atividade: Árvore dos sonhos).

"mais policiais nas ruas; que todo mundo ajude todo mundo; o fim das queimadas; que construam mais escolas; o fim do desemprego; o fim da crise da energia; uma vida melhor para todos." (Atividade: Árvore dos sonhos).

"que não haja tanta violência; que melhorasse a situações dos rios, menos poluição; que a policia comessasse (sic) a trabalhar com mais vontade; que os prefeitos, políticos emfim (sic) pagassem mais para os policiais; mais trabalhos; que não haja mais fome; os políticos não roubem o nosso dinheiro; que não haja mais drogas; que não haja mais doeças (sic) daquelas bravas...; mais amor ao próximo; mais Deus no coração." (Atividade: Árvore dos sonhos).

Chauí (1998), classifica a violência como "ato de brutalidade, sevícia e abuso físico e/ou psíquico contra alguém e caracteriza relações intersubjetivas e sociais definidas pela opressão e intimidação, pelo medo e o terror. A violência se opõe à ética porque trata seres racionais e sensíveis; dotados de linguagem e de liberdade, como se fossem coisas, isto é, irracionais, insensíveis, mudos e inertes ou passivos".

Castro (1994) comenta que há interesses sociais, políticos e econômicos na criação do sentimento de insegurança, pois ele desvia a atenção de outros problemas e facilita a imobilização da população. 
Chauí (1987) cita Descartes em seu texto "Sobre o medo" e explica "o medo é o contrário da ousadia, é a perturbação e espanto da alma que Ihe subtrai o poder de resistir aos males que ela pensa estarem próximos".

"meu sonho é não ter mais medo, medo de minha mãe sair casa, meu pai, meus irmão e nunca mais voltar." (Atividade: Árvore dos sonhos)

"eu queria morar num lugar melhor, que eu não tivesse tanto medo, como moro mais longe que os outros, eu queria ter socego (sic) pra andar onde eu quizesse (sic)." (Atividade: Árvore dos sonhos)

Abramovay (2001) relata que a violência vem ocupando espaços cada vez mais amplos nos meios de comunicação formais e informais. Essa consideração ajuda no processo de compreensão de que a violência tão intensamente explorada em todos os meios de comunicação, contribui na característica de nossa sociedade atual: que nossos laços individuais e coletivos entre a sociedade e o meio onde ela sobrevive se rompem ou auxilia no processo de ruptura (considerando o meio: o planeta, o continente, o país, a cidade... até a casa e a família).

Esse fato ocorre, pois a ligação entre "eu" e o que pertence ao "meu mundo" está fraca por causa da violência que impede um elo mais forte quando "eu sei" que nada irá durar por muito tempo, ou que nada sobreviverá.

Aliado a esse pensamento há a sensação de vítima que esses mesmos meios de comunicação divulgam amplamente. Santos (1995) enfatiza esse problema "virtualmente possível, pelo uso adequado de tantos e tão sofisticados recursos técnicos, a percepção é mutilada, e a mídia julga necessário, através do sensacional e do medo, captar atenção."

Em se tratando de meios de comunicação de massa e o tema violência, é muito difícil não sofrer do sentimento de insegurança, pois ela está sempre presente em diversos noticiários tanto televisivos quanto escritos ou radiofalados de forma sensacionalista e impositiva, tornando-nos todos vítimas caladas e impotentes. A capa da revista Veja (2002) simboliza perfeitamente esse 
pensamento: "a morte do prefeito sinaliza de modo trágico que ninguém está a salvo."

O tema violência também vem acompanhado de idealizações de paz e "mais amor".

"violência, falta de amor, desemprego, fome, falta de educação." (Atividade: Muro das lamentações).

"que todas as ruas sejam asfaltadas. Violência, drogas falta de amor no coração." (Atividade: Árvore dos Sonhos).

$\mathrm{Na}$ atividade "Tempestade cerebral" cujo tema era "minha casa", e na atividade "três coisas para o futuro", a principal questão levantada foi a da sobrevivência, caracterizada como proteção, abrigo, ausência de perigo, grande apego à família, seguida em menor proporção a aspectos ligados a religião e alimentos. A família é considerada bagagem fundamental na viagem para um lugar distante. Vale ressaltar que a atividade "Tempestade cerebral" foi feita em trios e por escrito, cada trio criava uma frase em dois minutos após a discussão sobre o tema proposto. As frases estão separadas por pontos, portanto cada frase é o produto de um trio.

"Eu te falo: minha casa. O que vem a sua cabeça? (pergunta formulada pela pesquisadora) Família, proteção. Igreja, escola, enfim tudo o que me protege. Tudo. Amor. Falta de conciensia (sic). Meus amigos. Minha família. Um lugar seguro, bom para receber amigos. Meu quarto, igreja, família. Lugar onde estou protegido. Família. Refúgio".

"Por que? (pergunta formulada pela pesquisadora) Porque eu fico segura. Vivo dentro de tudo isso. Aonde está as coisas e pessoas que eu mais preciso. Porque lá eu sei que estou protegida. Nela eu e meus familiares nos reunimos sem atritos e em paz. Pode fazer tudo que quizer (sic). Não sinto perigo de nada. Tem ar puro e tem as pessoas que eu amo. É um lugar onde me sinto seguro. Porque lá é que estão as pessoas que eu mais amo. É onde eu me sinto bem longe dos perigos". (Atividade: Tempestade minha casa).

"meu pai, minha mãe, minha tia, minha avó, meu tio, meu primo" (Atividade: Três coisas para o futuro). 
"alimentos, minha família e meus amigos, água" (Atividade: Três coisas para o futuro).

Lasch (1986) em seu trabalho sobre a sobrevivência afirma que a sensação de vítima torna as pessoas pouco participativas na sociedade, esse fato acontece como uma tentativa de proteção: “(...) Uma das razões pelas quais as pessoas não mais se vêem como sujeitos de uma narrativa é que elas não se vêem como sujeitos, de modo algum, mas como vítimas das circunstâncias; e essa sensação de deixar-se guiar por forças externas incontroláveis inspira um outro modo de armamento moral, uma retirada do eu sitiado rumo a personalidade de um observador irônico, separado e confuso. A sensação de que isto não está acontecendo comigo ajuda a proteger-me contra a dor e a controlar as expressões de ultraje ou rebelião que somente provocaria meus captadores a torturas adicionais".

\subsection{Volta ao passado, Fuga para o futuro e Sonhos de um mundo melhor.}

Há também uma interessante busca pela volta a um passado idealizado quando era possível ter amizades e outros valores positivos, entre eles principalmente uma condição financeira melhor e mais facilidade em arranjar empregos. Os estudos são cobiçados na intenção de conseguir obter um diploma e "ser alguém na vida". Novamente a violência Aparece como fator de inquietação.

Tuan (1980) afirma que uma das características da sociedade moderna contemporânea é sentir saudade, "quando um povo percebe que as mudanças estão ocorrendo muito rapidamente, rodando sem controle, a saudade de um passado idílico aumenta sensivelmente."

\footnotetext{
" que todos tenham paz, que a violência acabe. Que as pessoas voltem a ser como antes. Que a amizade de todos e entre todos seja bem melhor. Que as ruas voltassem a ter polícia. Que o rio voltece (sic) a ser limpo. Que todos voltem a ser feliz." (Atividade: Árvore dos Sonhos).
} 
"gostaria que tudo voltasse a ser como antes; sem violência, sem assassinatos, sem ganância, com pessoas humildes e amigas." (Atividade: Árvore dos Sonhos).

Carvalho (2001), avalia a competitividade e o individualismo como as duas mais importantes causas da fragilidade generalizada e do medo que afetam a população atualmente, e decorre deste fato, a propensão a aceitar a violência real ou simbólica como fatores que impossibilitam o resgate da cidadania. $O$ individualismo e a competitividade podem ser considerados algumas das características da sociedade contemporânea, entre inúmeras outras, como também a falta do sentimento de coletividade e coleguismo.

" que todos tenham uma vida melhor, sem violência, poluição desemprego, etc, mas para isso todos tem que colaborar" (Atividade: Árvore dos Sonhos).

"que todos vivem (sic) em paz e armonia (sic), que um ajude mais o outro, e que as coisas do "mundo" voutasse (sic) a ser como antes e que todos tenham menos violência e mais fé no coração de todos. Que a natureza seja como antes, para nós possamos (sic) passear e apreciar ela." (Atividade: Árvore dos Sonhos).

Os "sonhos de consumo" exaustivamente impostos pela mídia como atributos da felicidade são manifestados através dos discursos abaixo.

“meu sonho é ser jogador de futebol” (Atividade: Árvore dos Sonhos).

"ter uma vida normal não igual a vida que eu tenho; ter um Golf para eu namorar; montar uma banda de forró; casar com uma mulher tipo a Feiticeira." (Atividade: Árvore dos Sonhos). 


\subsection{A questão ambiental}

Em todas as atividades, os problemas ambientais específicos mais veiculados pela mídia em geral, aparecem somente num terceiro plano ${ }^{3}$ dos interesses e preocupações e são principalmente relatados através de exemplos, entre eles: poluição (do rio Atibaia), os desmatamentos, a falta de água e de chuvas, a crise de energia elétrica, e falta de consciência, sendo que ao serem indagados sobre o que isso significava todas as respostas se concentravam em uma única frase "não jogar lixo no chão".

"Queimadas, falta de água. Falta de energia. Falta de segurança, desmatamento. Poluição dos rios. Desemprego. Fome. Violência, falta de amizade, compaixão, falta de amor, sinceridade; não ter medicina suficiente; falta de alegria, a mais importante de todas, ter conciencia (sic)." (Atividade: Muro das lamentações)

"falta de segurança, queimada, falta de água, crise da energia elétrica, poluição do rio Atibaia." (Atividade: Muro das lamentações)

"a violência nas ruas e com o meio ambiente; drogas nas ruas com menores de idade e maiores; desemprego; fome; água; falta de médicos nos postos públicos; falta de respeito com o meio ambiente." (Atividade: Muro das lamentações)

Dividimos o grande tema a questão ambiental em cinco categorias: 6.3.1 Entendimento sobre meio ambiente; 6.3.2 Caracterização de problema ambiental; 6.3.3 Meios de comunicação; 6.3.4 Falta de conhecimento ambiental e 6.3.5. Participação nos assuntos ambientais.

\footnotetext{
${ }^{3}$ Em primeiro lugar, como já foi dito, Aparece a violência e / ou falta de segurança como o principal problema enfrentado, ou se não enfrentado, o que mais aflige e amedronta. Em segundo lugar estão a fuga para o futuro e os sonhos de um mundo melhor. Tais conclusões emergiram através da análise dos dados coletados.
} 


\subsubsection{Entendimento sobre meio ambiente}

De acordo com as respostas, obtidas na primeira pergunta do questionário, pode-se compreender que a maioria dos alunos considera a natureza como elemento principal do meio ambiente, seguindo a opinião dividida entre "lugar onde os seres vivos vivem" e "habitat, casa, ambiente onde vivemos". Há outras respostas menos expressivas relacionadas também a aspectos biológicos como "plantas e animais", "vida" e "tudo o que é natural" ou "onde vivemos com matas, rios e sem poluição". Reigota (1994), divide esse entendimento em três visões diferentes: antropocêntrica onde o homem ocupa o centro; biocêntrica onde os elementos biológicos estão no centro e globalizada que integra os dois anteriores. Percebe-se, portanto uma visão predominantemente biocêntrica, o ser humano separado do meio ambiente.

A pesquisa realizada em 2001 pelo MMA intitulada "O que o brasileiro pensa de meio ambiente e consumo sustentável?" mostra que para os brasileiros, como já indicavam também os estudos de 1992 e 1997, "meio ambiente é sinônimo de fauna e flora (...) mais da metade deixou de incluir os seres humanos (homens e mulheres), os índios e as favelas, bem como as cidades".

Tabela 1. Questão 1: Para você, o que é meio ambiente?

\begin{tabular}{lcc}
\hline Respostas & $\begin{array}{c}\text { No.de } \\
\text { respostas }\end{array}$ & $\begin{array}{c}\text { Porcentagem de } \\
\text { respostas }\end{array}$ \\
\hline Natureza & 10 & $37 \%$ \\
Lugar onde os seres vivos vivem & 5 & $18,50 \%$ \\
Habitat, casa, ambiente onde vivemos & 5 & $18,50 \%$ \\
Tudo & 2 & $7,50 \%$ \\
Vida & 1 & $3,70 \%$ \\
Onde vivem animais e plantas & 1 & $3,70 \%$ \\
Tudo o que é natural & 1 & $3,70 \%$ \\
Onde vivemos com matas, rios sem poluição & 1 & $3,70 \%$ \\
Não respondeu & 1 & $3,70 \%$ \\
\hline
\end{tabular}

$\mathrm{Na}$ atividade Tempestade Cerebral, as respostas quando a questão indagada era ambiente e o que primeiro vinha à cabeça, novamente as 
respostas retratam o ambiente como a natureza ou relacionados aos recursos naturais ou biológicos. Gonçalves (1989) afirma que a definição de natureza em nossa sociedade é "aquilo que se opõe à cultura. A cultura é tomada como algo superior e que conseguiu controlar e dominar a natureza." Pelas respostas exemplificadas abaixo pode-se concluir que os estudantes têm uma visão semelhante.

"Eu te falo: ambiente. O que vem a sua cabeça? (pergunta formulada pela pesquisadora) Árvores. Natureza. Natureza, ar que respiramos. Meio de preservação. O essencial para a vida. O lugar onde animais vivem. Puro, verde, cheiro de mata. Verde, ar, águas. Verde, florido, calmo e bonito. É um lugar para se viver. Ar puro, natural, árvores, etc. Natureza,ar natural, cheiro natural, os animais, pássaro, etc. Natureza. Ar puro, árvores, plantas, etc.. Árvores, rios, etc. Destruído, infelismente (sic). Natureza.

Por que? (pergunta formulada pela pesquisadora) Porque é parecido com a mata, a casa dos animais. Porque tem pessoas que não sabem que dependemos dele. Elas que fazem o ar mais puro para nós. É ela que faz o ambiente (o ar) que respiramos. sem ele não vivemos. $O$ ambiente depende da natureza. O meio ambiente precisa ser prezervado (sic). Porque ambiente é tudo. Sem a natureza nós não respiramos o ar puro.Por causa dos animais, vegetação, flores, árvores, etc, geralmente vejo no meio ambiente. Porque tem árvores, vegetais, ar, etc. Sem ambiente é impossível ter uma vida agradável" (Atividade: Tempestade cerebral: ambiente).

$\mathrm{Na}$ questão fechada $\mathrm{n}^{\circ} 14$, os elementos da natureza foram os mais identificados como parte do meio ambiente: "rios, lagos e mares", "vegetação, terra e montanhas" em $1^{\circ}$ lugar. Em $2^{\circ}$ lugar "chuvas e ventos", depois pelo "ar, céu" e "os animais" e as respostas em menor proporção são as que incluem elementos construídos pelo homem "sítio, chácaras e fazendas", "praças e parques", "ruas, calçadas, estradas" e "construções, casas, prédios, fábricas". Percebe-se uma acentuada tendência em se considerar meio ambiente somente os elementos naturais isolados, ou distanciados, do ser humano, ou ainda, não fazendo parte do chamado "meio ambiente". 
Tabela 2. Questão 14: O que faz parte do meio ambiente ?

\begin{tabular}{lcc}
\hline Respostas & $\begin{array}{c}\text { No.de } \\
\text { respostas }\end{array}$ & $\begin{array}{c}\text { Porcentagem } \\
\text { de respostas }\end{array}$ \\
\hline Rios, lagos, mares & 27 & $16,17 \%$ \\
Vegetação, terra, montanhas & 27 & $16,17 \%$ \\
Chuvas, ventos & 25 & $14,97 \%$ \\
Ar, céu & 23 & $13,77 \%$ \\
Os animais & 23 & $13,77 \%$ \\
Sítios, chácaras e fazendas & 15 & $8,98 \%$ \\
Praças, parques & 13 & $7,78 \%$ \\
Ruas, calçadas, estradas & 7 & $4,20 \%$ \\
O ser humano & 5 & $2,99 \%$ \\
Construções, casas, prédios, fábricas & 2 & $1,20 \%$ \\
\hline
\end{tabular}

Tuan em 1980 já analisava a diferente perspectiva que estava sendo observada a natureza "(...) Nos últimos séculos, o termo natureza tem perdido mais terreno. Hoje em dia falar da natureza é falar do campo e do selvagem; e selvagem (...), é uma palavra que entregou quase todo o seu poder para evocar assombro. A natureza perdeu as dimensões de altura e profundidade; ganhou qualidades menos pretensiosas de charme e de beleza natural. Neste sentido diminutivo, natureza evoca imagens semelhantes àquelas de campo, paisagem, cenário".

Mas ao contrário dessa visão simples e campestre, o ambiente tem uma dimensão muito maior, e complexa, segundo Leff (2001), o ambiente não é somente ecologia, "mas a complexidade do mundo; é um saber sobre as formas de apropriação do mundo e da natureza através das relações de poder que se inscreveram nas formas dominantes de conhecimento. A partir daí, abre-se o caminho que conseguimos para delinear, compreender, internalizar e finalmente dar seu lugar - em nome próprio - a complexidade ambiental".

O ambiente é uma grande integração de universos menores não isolados: a parte física, incluindo os recursos naturais e não naturais, a parte psíquica e social, o ser humano e todas suas interações e a parte ecológica, entre eles a biodiversidade de fauna e flora, ao mesmo tempo em que as decisões políticas e econômicas tomadas pelo ser humano recaem sobre o ambiente. 
Serres (1991) poeticamente classifica a natureza como sendo "o conjunto das condições da própria natureza humana, suas restrições globais de renascimento ou de extinção, o hotel que Ihe dá alojamento, calor e mesa - além disso, ela as tira, quando há um abuso. Ela condiciona a natureza que, agora, por sua vez, também a condiciona. A natureza se conduz como um sujeito".

Jacobi (1994) também considera a interferência humana na definição de meio ambiente. "Por meio ambiente se entende um habitat socialmente criado, configurado enquanto um meio físico modificado pela ação humana. Parte-se do pressuposto de que a percepção da questão ambiental, como qualquer outra em geral, é uma resultante não só do impacto objetivo das condições reais sobre os indivíduos, mas também da maneira como sua interveniência social e valores culturais agem na vivência dos mesmos impactos".

É importante destacar que o termo "meio ambiente" vem sendo usado com diversos significados, porém a intenção é indicar a idéia de um espaço onde os seres bióticos e abióticos vivem, interagem, transformam-se e transformam esse espaço, em se tratando do ser humano, o meio ambiente ganha o componente sociocultural. $\mathrm{O}$ homem ao permanentemente transformar seu meio ambiente, ele próprio, muda sua visão de meio ambiente.

\subsubsection{Caracterização de problema ambiental}

Respondendo a pergunta sobre o que são problemas ambientais, a maioria considera novamente o que prejudica destrói ou não faz parte da natureza como problema ambiental, seguido de exemplos "o lixo, os desmatamentos, e a poluição", percebe-se nessas respostas novamente uma tendência a elementos relacionados à natureza. Poucas respostas se incluem nas causas e efeitos desses problemas. Nota-se, portanto uma relação direta entre a natureza e o ambiente, e os grandes exemplos de problemas ambientais explorados na mídia. 
Tabela 3. Questão 2: No seu entender, o que são problemas ambientais?

\begin{tabular}{lcc}
\hline Respostas & $\begin{array}{c}\text { No.de } \\
\text { respostas }\end{array}$ & $\begin{array}{c}\text { Porcentagem } \\
\text { de respostas }\end{array}$ \\
\hline Lixo, poluição, desmatamento,etc & 7 & $26 \%$ \\
Problemas com a natureza & 6 & $22,20 \%$ \\
Destruição da vida & 3 & $11,10 \%$ \\
Coisas que prejudicam os seres vivos, a natureza & 3 & $11,10 \%$ \\
O que estamos sofrendo, onde vivemos & 2 & $7,40 \%$ \\
Falta de consciência ambiental & 1 & $3,70 \%$ \\
Males que levam a morte da natureza & 1 & $3,70 \%$ \\
Coisas que não fazem parte da natureza & 1 & $3,70 \%$ \\
Destruição da natureza & 1 & $3,70 \%$ \\
O que o homem prejudica a natureza & 1 & $3,70 \%$ \\
O que faz mal a natureza & 1 & $3,70 \%$ \\
\hline
\end{tabular}

A respeito de problemas ambientais, os exemplos: desmatamento e poluição das águas são os principais, seguidos da poluição do ar, depois das queimadas e outros com menor participação nas respostas: a extinção de animais, a caça e a pesca, as contaminações, a falta de água, de tratamento de esgotos, a matança de animais e o desagrado à natureza. Jacobi (1995) em sua pesquisa sobre Problemas ambientais e qualidade de vida na cidade de São Paulo - percepções, práticas e atitudes dos moradores comenta que os entrevistados residentes em áreas melhor equipadas, a poluição sonora e do ar aparece como principal problema, enquanto nas áreas carentes os problemas referem-se ao saneamento básico, depois a poluição dos rios, entre outros. Notase que o desmatamento e a poluição das águas são realmente problemas ambientais em Sousas e Joaquim Egídio, porém, na realidade, a poluição atmosférica não é um problema ambiental para os moradores de Sousas e Joaquim Egídio, mas sim de cidades bem maiores como Campinas, situada a 30 Km desses distritos, e São Paulo, distante 100 Km. Não há congestionamentos causados por excesso de veículos nem grandes indústrias poluidoras do ar, e uma boa parcela do que ainda resta de mata no município se encontra, justamente, em Joaquim Egídio e Sousas. Esse fato remete a uma outra questão, a de compreender a causa dos problemas ambientais de outras localidades estarem importunando e incomodando esse grupo de alunos. 
Leff (2001) discute a importância dos impactos econômicos e ambientais na "problemática ambiental (...) se por um lado, é percebida como resultado da pressão exercida pelo crescimento da população sobre os limitados recursos do planeta, por outro, é interpretada como o efeito da acumulação de capital e da maximização da taxa de lucro a curto prazo, que induzem a padrões tecnológicos de uso e ritmos de exploração da natureza, bem como formas de consumo, que vêm esgotando as reservas de recursos naturais, degradando a fertilidade dos solos e afetando as condições de regeneração dos ecossistemas naturais."

Tabela 4. Questão 3: Dê 5 exemplos de problemas ambientais

\begin{tabular}{lcc}
\hline Respostas & $\begin{array}{c}\text { No.de } \\
\text { respostas }\end{array}$ & $\begin{array}{c}\text { Porcentagem } \\
\text { de respostas }\end{array}$ \\
\hline Desmatamento & 23 & $20,36 \%$ \\
Poluição águas & 23 & $20,36 \%$ \\
Poluição do ar & 15 & $13,28 \%$ \\
Queimadas & 10 & $8,85 \%$ \\
Lixo & 8 & $7,08 \%$ \\
Extinção de animais & 7 & $6,20 \%$ \\
Caça e pesca & 6 & $5,30 \%$ \\
Contaminações & 6 & $5,30 \%$ \\
Falta de água & 4 & $3,54 \%$ \\
Falta de tratamento de esgotos, água tratada & 4 & $3,54 \%$ \\
Matança de animais & 3 & $2,65 \%$ \\
Desagrado a natureza & 3 & $2,65 \%$ \\
Falta de energia & 1 & $0,89 \%$ \\
\hline
\end{tabular}

Os itens assinalados com maior freqüência nessa questão fechada são: "poluição da água", "esgotos a céu aberto", "queimadas e corte de árvores", "extinção de animais e vegetais", "fumaça de carro e caminhão", "fumaça de chaminés", "lixo a céu aberto" e "trânsito". Seguindo em ordem decrescente de participação nas respostas: "falta de água", "falta de áreas verdes", "enchentes", "poeira", "fumaça de cigarros", "aumento de ratos e baratas", "contaminação do solo", "faixas e cartazes", "terremotos e furacões" e, finalmente, "buzinas".

Vale a pena ressaltar novamente a inexistência de problemas relacionados a poluição atmosférica causada por fumaça de carros, caminhões, chaminés, trânsito e enchentes na localidade dos subdistritos. Em pesquisa realizada no jornal da cidade, Correio Popular, sobre a ocorrência de enchentes ou 
congestionamentos causado por excesso de veículos, não havia nenhum relato nem registro nos subdistritos nos últimos dez anos anterior até a realização da pesquisa.

Tabela 5. Questão 12: O que você considera como problema ambiental?

\begin{tabular}{lcc}
\hline Respostas & $\begin{array}{c}\text { No.de } \\
\text { respostas }\end{array}$ & $\begin{array}{c}\text { Porcentagem } \\
\text { de respostas }\end{array}$ \\
\hline Poluição da água & 27 & $8,6 \%$ \\
Esgoto à céu aberto & 25 & $8,1 \%$ \\
Queimadas, corte de árvores & 24 & $7,69 \%$ \\
Extinção de animais e vegetais & 24 & $7,69 \%$ \\
Fumaça de carro, caminhão & 24 & $7,69 \%$ \\
Fumaça de chaminés & 24 & $7,69 \%$ \\
Lixo à céu aberto & 23 & $7,37 \%$ \\
Trânsito & 23 & $7,37 \%$ \\
Falta de água & 20 & $6,40 \%$ \\
Falta de áreas verdes & 18 & $5,77 \%$ \\
Enchentes & 18 & $5,77 \%$ \\
Poeira & 15 & $4,80 \%$ \\
Fumaça de cigarros & 15 & $4,80 \%$ \\
Aumento de ratos e baratas & 11 & $3,52 \%$ \\
Contaminação do solo & 10 & $3,20 \%$ \\
Faixas e cartazes & 4 & $1,28 \%$ \\
Terremotos e furacões & 4 & $1,28 \%$ \\
Buzinas & 3 & $0,96 \%$ \\
\hline
\end{tabular}

Tabela 6. Questão 4 A: No seu entender, existem problemas ambientais em Sousas e Joaquim Egídio?

\begin{tabular}{lcc}
\hline Respostas & $\begin{array}{c}\text { No.de } \\
\text { respostas }\end{array}$ & $\begin{array}{c}\text { Porcentagem } \\
\text { de respostas }\end{array}$ \\
\hline Sim & 24 & $88,89 \%$ \\
Não sabe & 3 & $11,11 \%$
\end{tabular}

Tabela 7. Questão 4 B: Quais ?

\begin{tabular}{lcc}
\hline Respostas & $\begin{array}{c}\text { No.de } \\
\text { respostas }\end{array}$ & $\begin{array}{c}\text { Porcentagem } \\
\text { de respostas }\end{array}$ \\
\hline Poluição do Rio Atibaia & 10 & $41,70 \%$ \\
Poluição dos Rios e do ar & 4 & $16,66 \%$ \\
Poluições dos rios, lixo, árvores derrubadas e destruição da natureza & 3 & $12,50 \%$ \\
Poluições ambientais & 3 & $12,50 \%$ \\
Lixo na rua & 2 & $8,32 \%$ \\
Incêndios em pastos e matas & 1 & $4,16 \%$ \\
Fogo na mata & 1 & $4,16 \%$ \\
\hline
\end{tabular}


Tabela 8. Questão 5 A: Você se incomoda com esses problemas ?

\begin{tabular}{lcc}
\hline Respostas & $\begin{array}{c}\text { No.de } \\
\text { respostas }\end{array}$ & $\begin{array}{c}\text { Porcentagem } \\
\text { de respostas }\end{array}$ \\
\hline Sim & 23 & $85,19 \%$ \\
Não & 1 & $3,70 \%$ \\
Não respondeu & 3 & $11,11 \%$ \\
\hline
\end{tabular}

Tabela 9. Questão 5 B: Por que?

\begin{tabular}{lcc}
\hline Respostas & $\begin{array}{c}\text { No.de } \\
\text { respostas }\end{array}$ & $\begin{array}{c}\text { Porcentagem } \\
\text { de respostas }\end{array}$ \\
\hline Nos prejudica & 9 & $39,16 \%$ \\
Fede e fica feio & 3 & $13,04 \%$ \\
Falta água & 3 & $13,04 \%$ \\
Polui o ar e as pessoas & 2 & $8,70 \%$ \\
Precisamos da natureza & 2 & $8,70 \%$ \\
Fede e mata animais & 1 & $4,34 \%$ \\
Desagrado ao M.A. & 1 & $4,34 \%$ \\
Vivo aqui & 1 & $4,34 \%$ \\
Acaba o verde & 1 & $4,34 \%$ \\
\hline
\end{tabular}

A maioria acredita que existem problemas ambientais em Sousas e Joaquim Egídio e se sentem incomodados com esses problemas.

A grande maioria considera problema a poluição dos rios, caracterizado principalmente pelo rio Atibaia, que passa por Joaquim Egídio e abastece o município como problema ambiental local. Outro número significativo considera a poluição dos rios e do ar e outros exemplos, e também a poluição ambiental, não especificando qual tipo de poluição, e a minoria relata que é o fogo, ou as queimadas o problema.

Muitos se sentem em prejuízo por isso se incomodam com os problemas. As outras opiniões ficam divididas em: aspectos estéticos e físicos (fica feio, odor ruim) ou ambientais (água, poluição, vegetação, fauna), e ainda em pequena porcentagem há o relato da idéia de pertencimento "precisamos da natureza" ou "vivo aqui".

Fazendo uma breve comparação entre os dados obtidos na pesquisa "O que o brasileiro pensa de meio ambiente e consumo sustentável?" (MMA, 2001) e os desta dissertação, nota-se uma certa coincidência, ao se perguntar sobre problemas ambientais, as respostas obtidas são problemas globais e não locais. 
Para os problemas locais aflorarem é necessário indagar sobre os problemas na cidade ou no bairro, como se o local não fizesse parte do global. Fica um questionamento de porque isso acontece, seria um distanciamento afetivo, ou um excesso informações na mídia sobre problemas mundiais?

Segundo MMA (2001: 08), “A população brasileira aponta o desmatamento, a contaminação dos rios, lagoas e praias, assim como do ar, como sendo os três principais problemas ambientais que assolam tanto o mundo quanto o País em nossos dias. Quando se trata de identificar problemas na cidade onde moram, ou no bairro, eles mudam de figura: coincidindo com os dados obtidos em 1997, em 2001, 18\% da população elegeram problemas de saneamento ambiental como coleta de lixo, limpeza de ruas e saneamento básico como os principais problemas que os afetam"

É interessante ressaltar que apesar de se sentirem incomodados com os problemas, eles não se incluem neles de modo como que somente em três respostas aparecem a $1^{\mathrm{a}}$ pessoa referindo-se a "eu" ou "nós".

\subsubsection{Meio de comunicação}

A televisão aparece em papel destacado como fonte de informação, o que indica uma possível visão distorcida da realidade. Andrade (1997) e Ramos (1994), em suas dissertações de mestrado sobre os meios de comunicação e o meio ambiente discutem a importância da forma como as informações ambientais são difundidas e exploradas pela mídia. Andrade (1997) afirma que a tendência na televisão é uma "abordagem simplista, incompleta e pouco sistemática, com predomínio de um tipo de tratamento padrão e oportunista, privilegiando o sensacional, o catastrófico, o impactante, o exótico, como forma de atingir e envolver o público". E completa: "todas (as informações ambientais veiculadas pelos meios de comunicação) partilham um sentido comum que identifica meio ambiente quase exclusivamente com o substrato de vida silvestre". Esse substrato da vida silvestre pode ser considerado como o selvagem, distante do cotidiano e da realidade vivida pela grande maioria da população brasileira. 
Tabela 10. Questão 13: Você costuma ter informações a respeito do meio ambiente por meio de

\begin{tabular}{lcc}
\hline Respostas & $\begin{array}{c}\text { No.de } \\
\text { respostas }\end{array}$ & $\begin{array}{c}\text { Porcentagem } \\
\text { de respostas }\end{array}$ \\
\hline TV & 27 & $38,57 \%$ \\
Jornais & 11 & $15,71 \%$ \\
Professor & 9 & $12,86 \%$ \\
Revistas & 8 & $11,42 \%$ \\
Rádio & 6 & $8,57 \%$ \\
Outros & 5 & $7,15 \%$ \\
Livros & 4 & $5,72 \%$ \\
\hline
\end{tabular}

A difusão da informação, diferentemente do passado, ocorre nos dias atuais de maneira muito veloz e difundida. Ramos (1995) tem uma interessante consideração a respeito: "Os últimos anos o planeta saiu da esfera do conhecimento local e regional, saltando para uma dimensão global, interligado pelas redes de comunicação e com o auxílio dos satélites computadorizados, qualquer ponto da terra pode ser visualizado e pesquisado, em qualquer momento, obtendo-se informações praticamente simultâneas sobre os mais diversos acontecimentos que envolvem o homem, a sociedade e a natureza".

Toda essa gigantesca cobertura mundial jornalística possivelmente causa uma absorção de realidades e problemas que não pertencem ao dia-a-dia, a região e a dinâmica de vida dos ouvintes. Problemas e realidades estrangeiras são incorporados e vividos como se fossem verdadeiros e imutáveis. Com certeza a difusão das informações tem suas boas características, por exemplo, mostrar ao mundo as áreas que necessitam de ajuda e apoio externo, ou as maravilhas culturais e artísticas de localidades outrora inimagináveis, ou ainda divulgar novas descobertas científicas e servir como potencial ferramenta educacional.

Costa \& Trajber (2002) alertam para essa problemática, "O despreparo dos profissionais da comunicação para as questões ambientais, e muito mais para a educação ambiental, leva à transmissão de conteúdos ambientais equivocados, de teor notadamente naturalista, privilegiando problemáticas globais, o que induz a população a pensar a realidade ambiental com base em temas distanciados de seu próprio cotidiano". 
$\mathrm{Na}$ atividade "Procura-se" observa-se que os animais silvestres são considerados aqueles que vivem no interior da mata e os exemplos são de animais cujo habitat não é na região. Seriemas, bugios, lontras, jaguatiricas e várias espécies de aves que residem na Apa não foram lembradas.

“14. Saiba o que é um animal silvestre.

Animal silvestre é caracterizado como aquele que vive no interior da mata.

Os exemplos são a arara-azul e a onça pintada. (Atividade: Procura-se).

"6. Saiba o nome de um animal brasileiro em extinção.

Todas as respostas eram idênticas, o animal citado era o mico-leãodourado". (Atividade: Procura-se).

"8. Saiba o nome de um rio de Campinas.

Todas as respostas citaram o rio Atibaia". (Atividade: Procura-se).

"6. Saiba o nome de uma árvore brasileira.

Todas as respostas citaram o Pau-Brasil". (Atividade: Procura-se).

Novamente percebe-se que problemas e informações globais amplamente difundidos pelos meios de comunicação são recordados muito mais facilmente do que os locais. O mico-leão-dourado é uma espécie ameaçada de extinção cujo habitat é a Mata Atlântica, no entanto não há relatos do aparecimento dela na região nos últimos 30 anos. O rio Atibaia passa por dentro das áreas da Apa e tem projetos de Educação Ambiental cuja propaganda estava estacionada nas proximidades da escola no período desta pesquisa, conforme já relatado no capítulo caracterização da área. Bem como a única árvore brasileira lembrada ser o Pau-Brasil, esta árvore foi a árvore-símbolo do plantio realizado em uma praça dentro da Apa e teve grande propaganda na cidade através de faixas e cartazes.

Ramos (1995) reflete sobre como a comunicação de massa atua, funcionando como um referencial do mundo exterior “(...) um sistema de representações que interage com o conhecimento pessoal direto, adquirido pelo 
indivíduo por meio de sua formação cultural, convivência social e experiência própria. É a partir dessa interação que se consolidam opiniões sobre o mundo, a sociedade e o meio ambiente".

$\mathrm{Na}$ atividade intitulada "Tinha um rio" os alunos, num círculo continuavam a estória iniciada por uma frase: Tinha um rio... e o aluno ao lado prosseguia até que todos tivessem participado. Pode-se perceber um certo pessimismo, uma tendência em ver o lado pior, tornando mais difícil estabelecimento de vínculos afetivos e talvez contribuindo com o "despertencimento".

"Tinha um rio / e ele era sujo / podre e fedido / cheio de lixo / e contaminação / e poluição / e os peixes estavam morrendo / de tantas doenças / estava sem vida / e não podíamos beber sua água / nem nadar / nem fazer nada / se o boi cair lá, ele morre / se a gente cair lá a gente também morre / tinha também um monte de rato / e barata". (Atividade: Tinha um rio).

"Tinha um rio / que virava uma cachoeira / linda e refrescante / com água gostosa / e tinha peixes e patos / e gansos / e a gente podia nadar / e beber / mas depois ele ficou feio e fedido / cheio de lixo / e de rato / a água era verde / às vezes ficava marrom / e se a gente beber dá dor de barriga / febre / vermes / e uma porção de doenças". (Atividade: Tinha um rio).

Andrade (1997) enfatiza um problema relacionado a uma estratégia de jornalismo, ao comentar sobre temas ambientai, há uma "distorção ideológica dos problemas reais". Conteúdos ambientais são veiculados sob uma visão parcial, criando a ilusão que representam o todo, e aspectos da vida social como sendo produto de processos naturais, juntamente com um oportuno toque de sensacionalismo. Essa visão parcial acarreta em uma maior dificuldade de participação e envolvimento nos assuntos ambientais, principalmente os locais.

\subsubsection{Falta de conhecimento ambiental}

A grande maioria desconhece o significado da palavra Apa. 
Tabela 11. Questão 10: Você sabe o que é Apa?

\begin{tabular}{lcc}
\hline Respostas & $\begin{array}{c}\text { No.de } \\
\text { respostas }\end{array}$ & $\begin{array}{c}\text { Porcentagem } \\
\text { de respostas }\end{array}$ \\
\hline Sim & 4 & $14,82 \%$ \\
Não & 23 & $85,18 \%$ \\
\hline
\end{tabular}

Do pequeno número de respostas obtidas (somente três), todas se referem a natureza, uma delas considera a Apa sem nenhuma importância. Pode-se perceber que não há um conhecimento sobre a Apa.

Tabela 12. Questão 11: O que significa Apa e qual sua importância?

\begin{tabular}{lcc}
\hline Respostas & $\begin{array}{r}\text { No.de } \\
\text { respostas }\end{array}$ & $\begin{array}{c}\text { Porcentagem } \\
\text { de respostas }\end{array}$ \\
\hline Associação de Proteção do Meio Ambiente - Proteger o Meio Ambiente & 2 & $50 \%$ \\
Quem protege a natureza & 1 & $25 \%$ \\
Associação de Proteção da Natureza - sem importância & 1 & $25 \%$ \\
\hline
\end{tabular}

"2. Saiba o nome da Apa de Campinas. (Atividade: Procura-se) Nenhuma resposta foi correta".

Todas as respostas estavam erradas. Existe a noção de que esse termo se relaciona a algo ambiental, porém não é sabido o que é realmente. Nas respostas foram citadas Associações de animais, de preservação ambiental entre outros.

A "ignorância" ou a falta de conhecimento sobre assuntos ambientais fica evidente no relato de Sposati (2001:30) "Ao discutirmos ambientalismo, podemos tornar clara a profunda ignorância do espaço onde vivemos. Nós não aprendemos a geografia da cidade, não sabemos o nome dos rios da cidade, o nome dos córregos da cidade, nós somos ignorantes do ambiente onde vivemos". A questão vai além; não conhecemos as árvores da nossa rua e da nossa cidade, os bairros vizinhos, mal conseguimos imaginar para onde escorre a água das chuvas, se o córrego mais próximo já fora canalizado, a quantos dias não chove, a montanha mais alta da cidade, quais pássaros cantarolam na alvorada.

Pode-se refletir a falta de conhecimento juntamente com a falta de participação e envolvimento nas questões ambientais. Nos assuntos em que há 
desconhecimento, não há opinião, inclusão. Sorrentino (2001: 218) escreve que "ligado ao conceito de participação temos o conceito de pertencimento, de pertença, de sentir-se pertencente, ao qual pode-se relacionar o de emancipação. A noção de identidade está relacionada à capacidade de visualizar o espaço e o tempo onde está inserido". Esse vínculo estabelecido entre o indivíduo e o espaço, pode ser resumido em "sentir-se parte", em ter o desejo (e não a obrigação) de em todos os momentos interagir nos assuntos relacionados a comunidade pois há a certeza que as decisões recairão sobre os membros dessa comunidade.

\subsubsection{Participação nos assuntos ambientais}

Aproximadamente 1/3 dos entrevistados inclui-se na responsabilidade pelo surgimento dos problemas ambientais, seguido de uma expressiva resposta que são "homens, jovens, adultos e crianças". O restante se divide entre: "todos os poluidores", "quem não tem consciência ou agride a natureza", "empresas, caçadores".

Tabela 13. Questão 6: Quem são os responsáveis pelo surgimento dos problemas ambientais ?

\begin{tabular}{lcc}
\hline Respostas & $\begin{array}{c}\text { No.de } \\
\text { respostas }\end{array}$ & $\begin{array}{c}\text { Porcentagem } \\
\text { de respostas }\end{array}$ \\
\hline Homens, jovens, crianças e adultos & 9 & $33.33 \%$ \\
Todos nós & 7 & $25.93 \%$ \\
Todos os poluidores, empresas, caçadores & 5 & $18.52 \%$ \\
Quem não tem consciência ou agride a natureza & 3 & $11.11 \%$ \\
Não respondeu, Não sabe & 3 & $11.11 \%$ \\
\hline
\end{tabular}

A solução dos problemas ambientais fica sob responsabilidade de "todos nós" para aproximadamente $1 / 3$ dos entrevistados. Seguido de diversas opiniões, como: "quem tem consciência", "bombeiros e defesa civil", "grupos ambientais", "quem não agride a natureza" e "todos nós e o governo".

O envolvimento, "sentir-se parte" relaciona-se com a responsabilidade, social e política, segundo Freire (1996), só se conquista tal responsabilidade de 
uma maneira: participando, "(...) Ganhando cada vez maior ingerência nos destinos da escola do seu filho. Nos destinos do seu sindicato. De sua empresa, através de agremiações, de clubes, de conselhos. Ganhando ingerência na vida do seu bairro, de sua Igreja. Na vida de sua comunidade rural, pela participação atuante em associações, em clubes, em sociedades beneficentes". (Freire 1996:92)

Tabela 14. Questão 7: Quem são os responsáveis pela solução desses problemas?

\begin{tabular}{lll}
\hline Respostas & $\begin{array}{c}\text { No.de } \\
\text { respostas }\end{array}$ & $\begin{array}{c}\text { Porcentagem } \\
\text { de respostas }\end{array}$ \\
\hline Todos nós & 9 & $37,50 \%$ \\
Não sabe, Não respondeu & 7 & $29,20 \%$ \\
Quem tem consciência & 3 & $12,50 \%$ \\
Bombeiros e defesa civil & 2 & $8,32 \%$ \\
Grupos ambientais & 1 & $4,16 \%$ \\
Quem não agride a natureza & 1 & $4,16 \%$ \\
Todos nós e o governo & 1 & $4,16 \%$ \\
\hline
\end{tabular}

Em se tratando da colaboração individual para conservar o ambiente em que vivem, a grande maioria coloca as atitudes individuais como "não jogar lixo no rio "não jogar lixo no chão", " seguidos de "não por fogo na mata", "não desmatar", "jogar lixo no lixo". E, uma minoria retrata outras atitudes consideradas mais vagas como "conscientizar", "não poluir", "não destruir" e outras mais genéricas: "não matar animais", "não caçar", "reciclar", "plantar árvores" e "economizar energia".

Percebe-se uma tendência em exemplificar a colaboração para conservação ligada a atitudes simples e individuais do dia-a-dia, como dar destino correto aos resíduos sólidos domiciliares e preservar a mata. Segundo a pesquisa do MMA (2001: 22) quando a pergunta solicitada era: O que estaria disposto a fazer para ajudar na proteção do meio ambiente? "Tanto em 1997 quanto em 2001, três itens fazem parte da cesta básica protetora dos nossos cidadãos: separação de recicláveis, eliminação do desperdício de água e energia (luz e gás)". 
Durante o ano de 2001, o país sofreu uma grave crise no abastecimento de energia elétrica, chamada de "apagão", intensas foram as campanhas nos meios de comunicação alertando sobre a necessidade de economia.

Jacobi (1997:02) discute a problemática ambiental a partir do viés da "participação democrática da sociedade na gestão dos recursos atuais e potenciais, assim como no processo de tomada de decisões para a escolha de novos estilos de vida e a construção de futuros possíveis, sob a ótica da sustentabilidade ecológica e da eqüidade social."

Tabela 15. Questão 8: Como você acha que as pessoas podem colaborar para melhorar e/ou conservar o ambiente em que vivem ?

\begin{tabular}{lcc}
\hline Respostas & $\begin{array}{c}\text { No.de } \\
\text { respostas }\end{array}$ & $\begin{array}{c}\text { Porcentagem } \\
\text { de respostas }\end{array}$ \\
\hline Não jogar lixo no rio & 20 & $28,98 \%$ \\
Não jogar lixo no chão & 9 & $13,04 \%$ \\
Não pôr fogo na mata & 8 & $11,59 \%$ \\
Não desmatar & 7 & $10,20 \%$ \\
Jogar lixo no lixo & 6 & $8,70 \%$ \\
Conscientizar & 4 & $5,79 \%$ \\
Não matar animais & 4 & $5,79 \%$ \\
Não poluir & 3 & $4,34 \%$ \\
Não destruir & 2 & $2,89 \%$ \\
Reciclar & 2 & $2,89 \%$ \\
Não caçar & 2 & $2,89 \%$ \\
Plantar árvores & 1 & $1,45 \%$ \\
Economizar água & 1 & $1,45 \%$ \\
\hline
\end{tabular}


Tabela 16. Questão 9: O que você tem feito para melhorar e/ou conservar o ambiente em que vive?

\begin{tabular}{lcc}
\hline Respostas & $\begin{array}{c}\text { No.de } \\
\text { respostas }\end{array}$ & $\begin{array}{c}\text { Porcentagem } \\
\text { de respostas }\end{array}$ \\
\hline Jogando lixo no lugar certo & 16 & $39,02 \%$ \\
Não jogando lixo no rio & 10 & $24,39 \%$ \\
Não poluindo o MA. & 3 & $7,31 \%$ \\
Não incendiando a mata, Não desmatando & 3 & $7,31 \%$ \\
Economizando água & 2 & $4,88 \%$ \\
Não matando animais & 2 & $4,88 \%$ \\
Limpando a casa, Reciclando & 2 & $4,88 \%$ \\
Não destruindo a natureza & 2 & $4,88 \%$ \\
Preservando o M.A & 1 & $2,45 \%$ \\
\hline
\end{tabular}

As atitudes concretas visando a melhoria do ambiente em sua grande maioria remetem a jogar o lixo no local correto, e este lugar não é o rio. Outras respostas, novamente condizem com a anterior, somente em duas respostas é considerado "limpar a casa" e "reciclando" como atitude de conservação do ambiente. 


\section{CONSIDERAÇÕES FINAIS}

“(...) todo desenvolvimento verdadeiramente humano

deve compreender o desenvolvimento conjunto das autonomias individuais, das participações comunitárias e da consciência de pertencer a espécie humana".

Edgar Morin

No longo caminho percorrido por esta pesquisa, alguns atalhos foram sendo delineados no decorrer do tempo. A idéia inicial, em se captar as "percepções ambientais" do grupo de alunos moradores de uma área de proteção ambiental foi ficando cada vez mais como uma rota alternativa e sendo substituída por uma outra trilha, a da tentativa de compreender as questões ambientais dentro do contexto de vida desses adolescentes, do seu dia-a-dia. Se tais questões realmente inquietavam, geravam preocupações e ações em relação ao futuro, se havia algum envolvimento, alguma participação na resolução dos problemas denominados "ambientais". Uma das primeiras pedras encontradas no caminho foi perceber um desconhecimento sobre a região onde vivem, moram e estudam. Mas essa pedra foi fundamental para interromper os pré-conceitos, as expectativas, as certezas, descansar e caminhar por entre as dúvidas, as incertezas, os questionamentos, e, descobrir que esse processo seria muito mais encantador e enriquecedor do que a busca incessante por respostas mais imediatas.

Outra parada importante foi a reflexão sobre "meio ambiente", de que maneira ele fazia parte (ou não fazia parte) da vida dessas pessoas, se essa interação gerava alguma ação, ou se não havia uma verdadeira apropriação, um forte vínculo com o lugar, uma "topofilia", para usar as palavras de Tuan (1980). Ao tentar entender sobre como se fazia esse laço de pertencimento, se realmente 
existiam essas amarras, foi ficando mais fácil traçar novos trajetos a serem percorridos.

Pensar em Meio Ambiente exige uma reflexão na complexidade desse termo, e pode ser considerado como o "espaço" (com seus componentes bióticos e abióticos e suas interações) em que um ser vive, se interage e se desenvolve. Dessa forma, Meio Ambiente significa: "o ar, o solo, a água; as plantas e os animais, inclusive o homem; as condições econômicas e sociais que influenciam a vida do homem e da comunidade; qualquer construção, máquina, estrutura ou objeto (...) resultantes direta ou indiretamente das atividades do homem; qualquer parte ou combinação dos itens anteriores e as interrelações de quaisquer dois ou mais deles" (Lago \& Pádua 2001).

Um dos objetivos da Educação Ambiental recomendados na Conferência Intergovemamental sobre Educação Ambiental aos Países Membros realizado em Tbilisi (1977), é justamente "lograr que os indivíduos e a coletividade compreendam a natureza complexa do meio ambiente natural e do meio ambiente criado pelo homem, resultante da integração de seus aspectos biológicos, físicos, sociais, econômicos e culturais, e adquiram os conhecimentos, os valores, os comportamentos e as habilidades práticas para participar responsável e eficazmente da prevenção e solução dos problemas ambientais, e da gestão da questão da qualidade do meio ambiente"

Portanto, é de fundamental importância a compreensão de meio ambiente integrando essa complexidade, e que dentro desse contexto fique claro que o meio ambiente engloba os seres humanos e suas múltiplas interações (a dimensão tecnológica, social, econômica, política, histórica, cultural, técnica, moral, estética, entre outras).

Contribuir para a formação de cidadãos conscientes, aptos para decidirem e atuarem na realidade sócio-ambiental de um modo comprometido com a vida, com o bem-estar de cada um e da sociedade, local e global. Para isso é necessário que, mais do que informações e conceitos, seja desenvolvido um espírito de crítica às induções ao consumismo e ao senso de responsabilidade e solidariedade no uso dos bens comuns e recursos naturais, de modo a respeitar o 
ambiente e as pessoas de sua comunidade. A responsabilidade e a solidariedade devem se expressar desde a relação entre as pessoas com seu meio, até as relações entre povos e nações, passando pelas relações sociais, econômicas e culturais.

Outro momento de grande reflexão foi o da tentativa de compreender como se manifestava o envolvimento, se existia alguma participação e comprometimento com as questões ambientais. É imprescindível a participação pessoal e coletiva nas atividades diárias da comunidade, atividades que envolvam tomadas de decisão diante de situações relacionadas ao meio ambiente.

Durante toda a elaboração desta dissertação, a participação foi pensada como um meio de se obter a sonhada melhoria das condições de vida e um acesso mais igual aos bens produzidos pela humanidade. Tassara et all (2002:156) discutem a participação sob o viés "Participação composta por uma esfera psicológica que nos fala de identidade e pertencimento social e por uma esfera política que nos fala da autonomia, interdependência e autogestão. Assim, sobrevivência e a participação constituem-se os ingredientes básicos para pensar a emancipação, mas exigem o cotejo de um debate crítico, histórico e multirreferenciado sobre valores individuais e coletivos, relativos ás idéias de felicidade e vida, essência e existência".

A participação tem relação direta com a existência do indivíduo no mundo e sua inserção no coletivo, a partir daí, o indivíduo se percebe como integrante do grupo. Costa-Pinto (2003) cita Sorrentino (2002) ao elencar algumas proposições que podem funcionar como indicadores de potência de ação:

a) Capacidade do indivíduo de refletir sobre seus desejos e aspirações e ter clareza do que realmente o mobiliza;

b) Capacidade do indivíduo de enunciar seus desejos para um coletivo;

c) Capacidade do indivíduo de ouvir o outro e respeitá-lo, respeitando seus desejos;

d) Capacidade do indivíduo perceber-se criticamente em um coletivo;

e) Capacidade do indivíduo de discutir/negociar seus desejos com os desejos dos outros (grupos ou indivíduos); 
f) Capacidade do indivíduo de realizar ações coletivamente, estando comprometido com a coletividade em questão;

g) Capacidade do indivíduo de analisar criticamente o que o distancia da realização de seus desejos;

h) Capacidade do indivíduo de avaliar as ações realizadas e os resultados obtidos;

i) Capacidade do indivíduo de debater alternativas e planejar soluções para os problemas que o distanciam de seus desejos;

j) Capacidade do indivíduo de se manifestar satisfeito com o rumo das ações empreendidas.

Costa-Pinto (2003) enfatiza a importância da potência de ação como elemento fundamental na construção da identidade local "Elementos estes que guardam em si uma riqueza cultural imensurável e que ao ser valorizada fortalece a identidade da população local e pode ser capaz de fornecer elementos de fundamental importância para se pensar em um desenvolvimento local compatível com a permanência e até incremento da biodiversidade".

Outra questão interessante foi a observação quanto ao grau de influência que os meios de comunicação, principalmente a televisão, conseguem atingir. Atua diretamente do cotidiano dos atores sociais envolvidos na pesquisa de forma muito ativa, dita regras de comportamento e consumo, impõem desejos e sonhos, mascara realidades, gera medos, angústias e obsessões. Em se tratando de questões ambientais, descontextualiza, compartimenta, supervaloriza de acordo com o interesse momentâneo. Ramos (1995) em seu trabalho sobre meio ambiente e meios de comunicação alerta “(...) o domínio da informação está diretamente ligado ao poder de interferir e reorientar as relações humanas e da sociedade com a natureza".

De acordo com as informações analisadas pode-se verificar um elevado grau de preocupação perante a violência, melhor definida como o temor a respeito da capacidade de sobrevivência, como se sobreviver fosse uma condição de 
prisioneiro / vítima primária da sociedade. Onde a sobrevivência é primordial, pois, a partir dela, podem ser definidas outras instâncias, mas na sua ausência todo o resto não existe. Se há dúvidas sobre a sobrevivência, o futuro fica completamente comprometido, há grande dificuldade em se estabelecer vínculos, compromissos e envolvimento.

Os trabalhos relacionados a EA podem se valer de elementos e mecanismos de valorização do meio ambiente, através da ampliação do universo de informações e de conhecimentos da importância da natureza. Segundo Liborio (1994:68) "Tendo conhecimento claro da situação, as pessoas tendem a despertar sua afetividade e, com isso, passam a valorizar a paisagem. A valorização implica atribuir a este recurso da natureza, as qualidades que o tornarão objeto de interesse e de proteção para toda a sociedade".

Pegoraro (1998) ao analisar os materiais da educação formal concluiu que o cotidiano urbano e a forma como se desenvolve o processo de escolarização, propicia mais o contato e o aprendizado a partir de ambientes bastante antropizados, de paisagens artificializadas e do excesso de espécies exóticas, contribuindo para manter em relativo anonimato a rica e diversificada flora e fauna nativa". E finaliza, comentando que a convivência, pode servir como "sede do aprendizado para obtenção de informações sobre a temática da flora, da fauna e dos ambientes naturais".

A conclusão da dissertação de mestrado de Hammes (1998) cujo tema é "Contribuições para o planejamento agroturístico na Área de Proteção Ambiental de Sousas e Joaquim Egídio (Campinas-SP) nos permite visualizar um bom caminho a ser percorrido, “(..) os principais impactos potenciais a implantação das atividades agroturísticas relacionam-se à erosão, destruição da cobertura vegetal e alterações provocadas na qualidade das águas. Permite concluir ainda que o principal elemento da mitigação dos impactos ambientais é a Educação Ambiental". (Hammes, 1998).

Pois se acredita que a "educação ambiental é um processo de reconhecimento de valores e clarificações de conceitos, objetivando o desenvolvimento das habilidades e modificando as atitudes em relação ao meio, 
para entender e apreciar as inter-relações entre os seres humanos, suas culturas e seus meios biofísicos. A educação ambiental também está relacionada com a prática das tomadas de decisões e a ética que conduzem para a melhora da qualidade de vida" Conferência Intergovernamental de Tbilisi (1977).

Santos \& Sato (2001) comenta que para que a transformação social, converta-se em ação epistemológica não se pode despedir de sua condição ontológica, reafirmando sua essência em bases técnicas e educativas, e legitimando o espaço político da cidadania.

As propostas abaixo podem servir como sugestões no sentido de auxiliar no delineamento de idéias para se trabalhar a EA em espaços escolares e em áreas de proteção ambiental.

a) Elaboração e implementação de programas de EA que contemplem as propostas da Política Nacional de Educação Ambiental, através de projetos que estimulem e apoiem construção de valores, atitudes, conhecimentos, competências que realmente contribuam para a participação de todos na busca de uma sociedade sustentável, para tanto é de fundamental importância o desenvolvimento de uma compreensão integrada do meio ambiente em suas múltiplas e complexas relações, envolvendo aspectos ecológicos, psicológicos, legais, políticos, sociais, econômicos, científicos, culturais e éticos.

b) Elaboração e disponibilização de material pedagógico adequado para cada comunidade, para que os moradores locais possam se sentir como parte integrante do aprendizado, reconhecendo-se, para que a atividade faça sentido junto a esse grupo, ou seja, contendo as características peculiares dos lugares, (pensando sempre nestes se tornarem territórios) tais como a diversidade de flora e fauna, valorizando as espécies nativas brasileiras.

c) Extensão das aulas para áreas da Apa, uso do espaço fora da sala-de-aula como recurso didático, utilizando-se de vivências e práticas contemplativas da natureza; 
d) Desenvolvimento de atividades que potencializem o envolvimento e estimulem a descoberta da importância de se constituir como ser participante, repensando as atitudes diárias; Intervenções educacionais possibilitando mergulho na própria realidade, alimentando o enraizamento; Compreensão da comunidade local como parceira; Elaboração de técnicas que estimulem o sentimento de pertença.

e) Pensando em tais programas de EA é muito importante estimular a participação direta respeitando as idiossincrasias, buscando criar espaços permanentes de discussão, sendo necessário um planejamento incremental que possa ir se adequando ao longo do processo. Etapas avaliativas são também imprescindíveis de modo que todos os envolvidos direta ou indiretamente consigam aumentar seus repertórios visando uma maior ingerência nas suas vidas, uma maior atuação política e uma real participação nas questões que envolvem sua comunidade.

f) 
ANEXOS 


\section{ANEXOS}

\section{Anexo A - Questionário}

Questionário

Bairro em que mora Cidade

Sexo Masc. () Fem.()

Data de Nascimento 1

Questionário (1º parte)

1) Para você, o que é meio ambiente?

2) No seu entender, o que são problemas ambientais?

3) Dê 5 exemplos de problemas ambientais.

4) Para você, existem problemas ambientais em Joaquim Egidio e Sousas? Quais?

() Não existem. () Não sei. () Sim, existem. Quais?

5) Você se incomoda com esses problemas?

6) Quem são os responsáveis pelo surgimento de problemas ambientais?

7) Quem são os responsáveis pela solução desses problemas?

8) Como você acha que as pessoas podem colaborar para melhorar e/ou conservar o ambiente em que vivem?

9) O que você tem feito para melhorar e/ou conservar o ambiente em que vive?

10) Você sabe o que significa Apa? ( ) Sim ( ) Não.

11) O que significa e qual a sua importância?

Questionário ( $2^{\circ}$ parte)

12) O que você considera como problema ambiental? *Obs: Assinale quantos itens quiser. () Falta de água () Aumento de ratos, baratas () Poluição das águas () Poeira () Esgoto a céu aberto () Fumaça de cigarros () Buzina () Lixo a céu aberto () Fumaça de chaminés de indústrias () Enchentes () Faixas e cartazes nas ruas () Fumaça de carro, ônibus e caminhão () Falta de áreas verdes (como parques e praças) () Contaminação do solo (por agrotóxicos, fezes) () Trânsito () Corte de árvores, queimadas () Terremotos, furacões () extinção de espécies animais e vegetais () outros. Quais?

13) Você costuma ter informações a respeito do meio ambiente por meio de:

*Obs: assinale quantos itens quiser. 
() Livros () Revistas () Televisão () Jornais () Rádio () Professor () Outras fontes. Quais?

14) O que faz parte do meio ambiente? *Obs assinale quantos itens quiser.

() Rios, lagos, mares () O ser humano () Praças, parques () Ruas, calçadas, estradas () Ar, céu () Os animais () Construções, casas, prédios, fábricas () Sítios, chácaras, fazendas () Vegetação, terra, montanhas () Chuvas, ventos() Outros. Quais?

Baseado no questionário desenvolvido por PELICIONI, A. F. (1998). 


\section{Anexo B - Atividade Tempestade Cerebral e Procura-se}

Tempestade cerebral

Eu te falo: Minha casa.

O que vem a sua cabeça?

Por que?

Eu te falo: Ambiente.

O que vem a sua cabeça?

Por que?

Eu te falo: Apa.

O que vem a sua cabeça?

Por que?

Eu te falo: Água.

O que vem a sua cabeça?

Por que?

\section{Procura-se}

1. Tenha ido ao Parque Santa Genebra.

2. Saiba o nome da Apa de Campinas.

3. Não goste de praia.

4. Tenha visto um animal nas matas de Joaquim Egidio.

5. Use meias amarelas.

6. Saiba o nome de um animal brasileiro em extinção.

7. Não tenha nojo de lesma.

8. Saiba o nome de um rio de Campinas.

9. Tenha medo do escuro.

10. Saiba o nome de uma árvore brasileira.

11. Já tenha ido a alguma cachoeira em Joaquim Egídio.

12. Saiba o que significa Apa.

13. Tenha medo de trovão.

14. Saiba o que é um animal silvestre.

15. Conheça alguém que more em fazenda em Joaquim Egidio.

16. Conheça outro país.

17. Tenha um animal silvestre em casa.

18. More em sítio.

19. Tenha medo de aranhas. 


\section{Anexo C - Respostas}

\section{Árvore-dos-Sonhos}

"sem violência, sem fome, todos preservando a natureza, sem poluição, ter água para todos" Árvore dos Sonhos

" que todos tenham uma vida melhor, sem violência, poluição desemprego, etc, mas para isso todos tem que colaborar" Árvore dos Sonhos

"que todos vivem em paz e armonia (sic), e que as coisas do "mundo" voutasse (sic) a ser como antes e que todos tenham menos violência e mais fé no coração de todos. Que a natureza seja como antes, para mós possamos passear e apreciar ela." Árvore dos Sonhos

"Gostaria que tudo voltasse a ser como antes; sem violência, sem assassinatos, com pessoas humildes e amigas." Árvore dos Sonhos

"que todos tenham paz, que a violência acabe. Que as pessoas voltem a ser como antes. Que a amizade de todos e entre todos seja bem melhor. Que as ruas voltassem a ser asfaltadas. Que o rio voltece (sic) a ser limpo. Que todos voltem a ser feliz." Árvore dos Sonhos

"que não tivesse mais violência no mundo; que não tivesse mais crianças nas ruas; mais áreas verdes, mais parques; mais amor" a vida e ao próximo; mais preservação na natureza; que não tivesse mais drogas; mais áreas preservadas; mais praças; mais ruas asfaltadas." Árvore dos Sonhos

"mais escolas, mais liberdade; mais lazeres; o fim da violência; mais chuvas; mais amor. Árvore dos Sonhos

"que todas as ruas sejam asfaltadas. Menos violência e mais amor no coração. Que ,minha família voute (sic) a ser feliz." Árvore dos Sonhos

"mais policiais nas ruas; que todo mundo ajude todo mundo; que o rio volte a ser limpo; o fim das queimadas; que construam mais escolas; o fim do desemprego; o fim da crise da energia; uma vida melhor para todos." Árvore dos Sonhos

"mais escolas; mais Apa; mais lazer; o fim da violência; não ter mais criança na rua; mais amor" Árvore dos Sonhos

"que não haja tanta violência; que melhorasse a situações dos rios, menos poluição; que a policia comessasse (sic) a trabalhar com mais vontade; que os prefeitos, políticos emfim (sic) pagassem mais para os policiais; mais trabalhos; que não haja mais fome; os políticos não roubem o nosso dinheiro; que não haja mais drogas; que não haja mais doeças (sic) daquelas bravas...; mais amor ao próximo; mais deus no coracao." Árvore dos Sonhos

"mais preservação do meio ambiente; mais escolas; um fim "a violência; nada de drogas; mais segurança; mais amor; mais lazer" Árvore dos Sonhos

"harmonia entre pessoas; paz; um meio ambiente completo; mais lugares para passear; mais verde; mais empregos; mais escolas; mais preservações; aumento salariais; rios limpos; casa para todos se abrigar; presidentes justos, mais cadeias; todos com mesmo estilos de vida; pessoas de bons sentimentos." Árvore dos Sonhos

"ver a vida de uma forma diferente como se nada de mal tive-se (sic) acontecido." Árvore dos Sonhos 
"que não tivesse violência, drogas, fome, abandono, morte, desemprego e que tivesse saúde, emprego, alimentação." Árvore dos Sonhos

"mais policiais na rua; rios limpos; mais Apa; não ter crianças nas ruas; que não existice (sic) violências nas ruas; tivese (sic) amor ao ambiente; amor ao próximo; que não existice (sic) a ceca (sic)." Árvore dos Sonhos

"meu sonho é ser jogador de futebol" Árvore dos Sonhos

"rios limpos para a pesca; que a violência acabe; que as pessoas ajudem os mais necessitados; que tivesse mais Apa para proteger as matas, rios e animais; que as pessoas sejam mais felizes; que acabe a fome; que eu seja feliz também."18 Árvore dos Sonhos

"tivesse mais paz no mundo; ser campeão mundial de tae kan do; conhecer todas as reservas naturais do mundo; conhecer o brasil inteiro; que não tivesse violência, etc."Árvore dos Sonhos

"eu queria ser um profissional qualificado; a restauração do rio atibaia e do meio ambiente; ter saúde e não ouvese (sic) mais fome e violência." Árvore dos Sonhos

"eu queria um bom emprego para mim; morar num lugar bom; que não existisse a fome; que eu e minha família tivesse-mos muita saúde." Árvore dos Sonhos

"eu gostaria que eu e a minha família tivesse uma saúde muito boa; que não existisse nem fome e nem desemprego; que eu tivesse um emprego muito bom; que não existisse falta de água, de alimento e de nenhum outro recurso que eu precisasse." Árvore dos Sonhos

"meu sonho é ver o mundo de uma forma diferente, por exemplo: acabar com a violência, com as drogas e outras coisas. Meu sonho também é estudar para ser alguém na vida e ajudar os que precisa. Também ter ao meu lado uma pessoas legal, amoroso e que eu ame muito." Árvore dos Sonhos

"conseguir me formar, um mundo melhor; ser feliz; viver um lugar bom; viver em um paraisso (sic); que não existisse nada de ruim." Árvore dos Sonhos

"ter uma vida normal não igual a vida que eu tenho; ter um Golf para eu namorar; montar uma banda de forró; casar com uma mulher tipo a Feiticeira." Árvore dos Sonhos

\section{Muro das lamentações}

"não ouvesse (sic) drogas; não tivesse violência; que as pessoas tivessem conciencia (sic) ao queimarem as florestas; e que todos vivesse num mundo de paz e armonia (sic)" Muro das lamentações

"Piorou a violência na cidade de Campinas mas melhorou um pouco um pouco não melhorou muito; a união entre as pessoas mas acho que o que fizeram com a fazenda Santa Maria colaboraram e muito para a sua reforma e isso que as pessoas tem que ser consientisa !!!! (sic).” Muro das lamentações

"A violência e que as pessoas se consientizacem (sic) e cuidasem (sic) e cuidasem (sic) do meio ambiente em que vivemos." Muro das lamentações

"queimadas; falta de água; falta de energia; falta de segurança; desmatamento; poluição dos rios; desemprego; fome ; violência; falta de amizade, compaixão, amor, sinceridade; não ter medicina suficiente; falta de alegria, a mais importante, ter conciencia (sic)." Muro das lamentações 
"a violência nas ruas com o meio ambiente; drogas nas ruas com menores de idade e maiores; desemprego; fome; água; falta de médicos nos postos públicos; falta de respeito com o meio ambiente." Muro das lamentações

"falta de água; violência; racionamento de energia elétrica; crianças sem escola; desemprego; fome; falta de respeito com próximo; falta de medicamento para quem precisa; falta de médicos nos hospitais; mais policiais nas ruas." Muro das lamentações

"morte; violência, muita droga; um tempo atrás morria um por dia; fome; sem terra, que não tem onde morar; eu não queria que fosse, eu queria morar num bairro tranquilo." Muro das lamentações

"eu gostaria que tivesse menos violência e que as pessoas cuidasem (sic) do meio ambiente em que vivemos e da falta de água no nosso planeta." Muro das lamentações

"violência, fome, roubo, desemprego, sem terra, desmatamento, falta de água, muitas drogas, amor, amizade." Muro das lamentações

"violência, conscientização, amor ao próximo, amizade, desemprego, fome, falta de educação." Muro das lamentações

" Gostaria que não houvesse violência, drogas, cigarro..., que as pessoas se conscientizasem (sic) (que não poluam os rios, as matas, etc), que o mundo fosse melhor". Muro das lamentações

"eu gostaria que não ouvesse (sic) desmamamento das matas; que não ouvesse (sic) queimada das matas; que ninguém desperdissasse (sic) água; que não matassem os animais; que o homem se conscientiza-se (sic) de que deveria conservar a natureza (a fauna e a flora)." Muro das lamentações

"os assaltos que estão começando a acontecer; o assassinato do meu amigo que aconteceu semana retrazada (sic) aqui em Sousas; a poluição do rio Atibaia que passa em Sousas." Muro das lamentações

"seca, violência, energia elétrica, fome, descriminação, desemprego" Muro das lamentações

"falta de água; poluição; violência entre pessoas; queimadas; falta pessoas para ajudar no meio ambiente; fome; mortes;crianças trabalhando; pessoas roubando; pessoas sem escola pra frequentar; diferença social; desemprego." Muro das lamentações

" poluição do rio, violência na rua, desrespeito entre todos, falta de chuva, falta de Deus no coração, morte, as drogas, desemprego, enfim tudo isso e mais um pouco é lamentável." Muro das lamentações

"violência, seca, falta de fiscalização, desigualdade social, queimada, poluição do rio." Muro das lamentações

"falta de água, violência, poluição, falta de trabalho, falta de energia, falta de amor a próximo". Muro das lamentações

"violência, desrespeito aos mais velhos, problemas com a natureza, desrespeito com algumas crianças, falta de chuva, seca, crise da energia elétrica. "Muro das lamentações 
"queimadas, a violência, poluição, falta de água, falta de trabalho,a crise da energia elétrica, preconceito." Muro das lamentações

"queimação (sic) do ambiente e desmatamento e poluição... gastancia (sic) de água e falta de segurança. " Muro das lamentações

"falta de segurança, queimada, falta de água, crise da energia elétrica, poluição do rio Atibaia." Muro das lamentações

"falta de segurança; as queimadas; desmatamento; falta de água suficiente para nós; poluições na natureza; falta de energia elétrica; falta de trabalho, falta de amor ao próximo; falta de educação." Muro das lamentações

"a violência, o desemprego, as mortes de pessoas inocentes, assalto nas ruas e as drogas." Muro das lamentações

"a violência nas escolas e outros lugares, o desemprego, mortes com pessoas inocentes, tráfico de drogas, assaltos em Sousas, principalmente, falta de chuvas, assassinatos e o descuidado das pessoas com a natureza." Muro das lamentações

"violência, seca, energia elétrica, fome, descriminação, desemprego."

Muro das lamentações

"a violência que está cada vez pior, a falta de chuva, as queimadas, falta de fiscalização; seca, que está ocorrendo por causa da falta de chuva; crise da energia elétrica, o rio Atibaia que a cada dia está mais baixo, problema com natureza." Muro das lamentações

\section{Tempestade cerebral}

Eu te falo: APA

O que vem a sua cabeça? Um projeto para proteger ao meio ambiente. Meio de preservação. Um progeto (sic) que protege o pouco que temos do meio ambiente. Criada para ajudar o meio ambiente. Que ainda a (sic) uma esperança. Proteção, conservação e muita forca de vontade.

Por que? O homem tem a mania de maltratá-lo. Nós ajuda (sic) a preservar a natureza. Porque o nosso meio ambiente está necessitando da ajuda da Apa. Porque o meio ambiente precisa de cuidados e várias pessoas não vem isso. Porque eles lutam para proteger o que ainda resta.

Eu te falo: MINHA CASA

O que vem a sua cabeça? Igreja, família, comunhão. Igreja, escola, enfim tudo ao meu redor. Tudo. Amor. Falta de conciensia (sic). Meus amigos. Minha família. Um lugar tranqüilo, bom para receber amigos. Meu quarto, igreja, família. Lugar onde estou protegido. Família. Refugio.

Por que? Porque eu participo disso. Vivo dentro de tudo isso. Aonde está as coisas e pessoas que eu mais preciso. Porque lá eu sei que estou protegida. Nela eu e meus familiares nos reunimos sem atritos e em paz. Pode fazer tudo que quizer (sic). Não sinto perigo de nada. Tem ar puro e tem as pessoas que eu amo. É um lugar onde me sinto seguro. Pq. Lá é que estão as pessoas que eu mais amo. É onde eu me sinto bem longe dos perigos.

\section{Eu te falo: AMBIENTE}

O que vem a sua cabeça? Destruído, infelismente (sic). Árvores. Natureza. Natureza, ar que respiramos. Meio de preservação. O essencial para a vida. O lugar onde vivemos. Puro, verde, cheiro de mata. Verde, ar, águas. Verde, florido, calmo e bonito. É um lugar para se viver. Ar puro, natural, árvores, etc. Natureza,ar natural, cheiro natural, os animais, pássaro, etc. Natureza. Ar puro, árvores, plantas, etc.. Árvores, rios, etc. Natureza.

Por que? Porque é parecido com a mata, a casa dos animais. Porque tem pessoas que não sabem que dependemos dele. Elas que fazem o ar mais puro para nós. É ela que faz o ambiente (o ar) que respiramos. sem ele não vivemos. O ambiente depende da natureza.O meio ambiente 
precisa ser prezervado (sic). Porque ambiente é tudo. Sem a natureza nós não respiramos o ar puro.Por causa dos animais, vegetação, flores, árvores, etc, geralmente vejo no meio ambiente. Porque tem árvores, vegetais, ar, etc. Sem ambiente é impossível ter uma vida agradável.

Eu te falo: ÁGUA

$\mathrm{O}$ que vem a sua cabeça? Vida. Um meio de sobrevivência. A importância de todos os seres. Uma cachoeira com pedras no meio. Vida, natureza. Vida. Sem ela não sobrevivemos. Mar. Vida. Sem a água nós não sobreviveríamos. Alimento. O que vem a sua cabeça? Um produto que necessitamos. Bactérias. Limpa. Água para nós é que nem um pedaço do nosso corpo. Frescor, gelada e saudável.

Por que? Porque sem ela não sobrevivemos. Ultimamente os rios estão muito poluídos, sem água não há vida. Porque sem ela não sobrevivemos. Pois sem ela não vivemos. Porque a água é fundamental, vida. Faz parte da natureza. sem água nós não vivemos. Porque sem ela não sobrevivemos. Lavamos e regamos todos os nossos alimentos. Porque eu gosto e faz bem a saúde.Todos bebem. É essencial. Porque é essencial a nossa vida. Porque sim.Porque com a água nós fazemos tudo que necessitamos e sem ela morreremos. Tudo que um ser vivo precisa para sobreviver. Não quero pessoas morrendo por causa das bactérias. Sem água nós não sobrevivemos.

\section{Três coisas para o futuro}

"meu pai";"meu cachorro"; "minha mãe" Três coisas para o futuro

"meu pai";"minha mãe"; "a Ester e deus no coração" Três coisas para o futuro

"meu pai";"meu cachorro"; "minha mãe" Três coisas para o futuro

"minha família";"bolacha, água, leite, coca-cola, hambúrguer"; "remédios" Três coisas para o futuro

"meu pai","minha mãe"; "minha irmã" Três coisas para o futuro

"meu pai";"minha irmã"; "minha mãe" Três coisas para o futuro

"meus irmãos, minha irmã";"meu pai"; "minha mãe" Três coisas para o futuro

"minha família";"a medica do Hopi Hari"; "chocolate, cachorro-quente, hambúrguer, leite e água" Três coisas para o futuro

"meu pai e minha mãe";"meu irmão"; "meu time do coração, São Paulo"

Três coisas para o futuro

"meu pai";" minha mãe"; "minha tia, minha avó, meu tio, meu primo"

Três coisas para o futuro

"meu pai";"minha mãe" Três coisas para o futuro

"todos os meus amigos porque eu os amo" Três coisas para o futuro

"água, árvores";"meu pai, minha mãe"; "meu cachorro" Três coisas para o futuro

"família"; "amigos" Três coisas para o futuro

"minha família";"árvore";"água" Três coisas para o futuro

"meu pai, minha mãe, meu irmão, minha irmã e amor";"a natureza"; "e também, fé em Deus, meus amigos, a água e muito alimento, e meu cãozinho também" Três coisas para o futuro

"água";"o amor"; "minha mãe, meu pai, meu irmão e meu sobrinho,mais minhas tias e amigos, porque e amo eles" Três coisas para o futuro

"água";"natureza"; "minha mãe, meu pai, meus irmãos" Três coisas para o futuro

"alimentos";"minha família e meus amigos";"água" Três coisas para o futuro

"natureza";"amor";"água" Três coisas para o futuro

"minha mãe";"meu namorado";"água e comida" Três coisas para o futuro

"meu namorado";"água";"comida e sementes" Três coisas para o futuro

"minha mãe;"meu pai";"leite" Três coisas para o futuro

"o Luis Felipe";"comida";"água" Três coisas para o futuro

"minha mãe";" comida";"água" Três coisas para o futuro

"minha mãe";"meu pai";"água e comida" Três coisas para o futuro

"o amor";"plantas";"água" Três coisas para o futuro

"bíblia";"sementes";"água" Três coisas para o futuro 


\section{REFERÊNCIAS BIBLIOGRÁFICAS}

AB'SABER, A. Re-conceituando a educação ambiental. In: MAGALHÃES, L.E. (coord.) A Questão Ambiental. São Paulo: Terragrah, 1994. 345p.

ABRAMOVAY, M. Escola de paz. UNESCO. Rio de Janeiro: Secretaria de Estado da Educação, 2001. 153p.

ANDRADE, S.I.M. Meio Ambiente e meios de comunicação de massa: uma crítica ao naturalismo. São Paulo, 1997. 142p. Dissertação (Mestrado) - Escola de Comunicação e Artes, Universidade de São Paulo.

ANGELO, C. Humanidade precisa de mais meia Terra. Folha de São Paulo. Caderno Folha Ciência. São Paulo, 21 out. 2000. p. A18.

ANGELO, C. Terra vive encruzilhada ecológica, diz ONU. Folha de São Paulo Caderno Folha Ciência. São Paulo, 23 maio 2002. p. A16.

ARENDT, H. Sobre a violência. Rio de Janeiro: Relume Dumará,1994. 114 p. 
BATISTELlA, M.B.; COUTINHO, A.C.; MIRANDA, J.R.; MIRANDA, E.E. de. Cartografia dos remanescentes florestais do Município de Campinas, SP, Brasil. In: SIMPOSIO LATINOAMERICANO DE PERCEPCION REMOTA, 7., Puerto Vallarta, México, 1995. Memórias S.L. Sociedad Latinoamericana de Percepción Remota y Sistemas de Información Espacial. p. 46-51.

BECKER, H. S. Métodos de pesquisa em ciências sociais. São Paulo: Hucitec, 1994. 159p.

BENEVIDES, M.V. A cidadania ativa: referendo, plebiscito e iniciativa popular. São Paulo: Ática,1991. 208p.

BENEVIDES, M. V. Cidadania e justiça. In: ALVES, M.L.; GROSBAUM, E.; MARTINS, A.M. Violência, um retrato em branco e preto. São Paulo: Editora Fde, 1994. 47p.

BENEVIDES, M. V. Educação para a democracia. Cultura e Política, v.38. p 1840. 1999.

BOGDAN, R.C.; BIKLEN, S. K. Investigação qualitativa em educação: uma introdução a teoria e aos métodos. Porto: Porto Editora, 1982. 335 p.

BRANDÃO, C.R. O que é educação? 33 ed. São Paulo: Brasiliense, 1995. 116p.

BRASIL. Ministério de Desenvolvimento Urbano e Meio Ambiente. Secretaria Especial do Meio Ambiente. Áreas de Proteção Ambiental: abordagem histórica e técnica. Brasília: SEMA - SEC - Coordenadoria de Áreas de Proteção Ambiental, 1987. 45p.

CARVALHO, S. Violência e cidadania um dialogo impossível. Revista THOT, n.76, p. 37-42, 2001. 
CASTRO, L.A. Olhar sobre a América Latina. In: RAMOS, S. (org.). Mídia e violência urbana. In: SEMINÁRIO MÍDIA \& VIOLÊNCIA RELATOS. Rio de Janeiro, 1994. 1-2 jul. Anais. Rio de Janeiro: FAPERJ, 1993. p.30.

CECCON, C.; OLIVEIRA, M.D.; OLIVEIRA, R.D. A vida na escola e a escola da vida. 21. ed. Rio de Janeiro: ED Petrópolis, 1990. 95p.

CHAUI, M. Sobre o medo. In: CARDOSO, S. Sentidos da paixão. São Paulo: Companhia das letras, 1987. p. 35-75.

CHAUI, M. Uma ideologia perversa: explicações para a violência impedem que a violência real se torne compreensível. Folha de São Paulo. Caderno Especial, São Paulo, 03 out. 1998. p. 04.

COSTA, L.B.;TRAJBER, R. Avaliando materiais audiovisuais de educação ambiental. In: COSTA, L.B.;TRAJBER, R. Avaliando a educação ambiental no Brasil. São Paulo: Editora Peirópolis - Instituto Ecoar para a cidadania, 2002. p. 12-28.

COSTA-PINTO, A. B. Em busca da potência de ação: Educação ambiental e participação na agricultura caiçara no interior da área de proteção ambiental de Ilha Comprida, SP. São Paulo, 2003. 209p. Dissertação (Mestrado) Ciência Ambiental, Universidade de São Paulo.

DALLARI, D. Direito de participação. In: SORRENTINO, M. (org.) Ambientalismo e participação na contemporaneidade. São Paulo: Educ/Fapesp. 2001. 229p. 
DEL RIO, V.; OLIVEIRA, L. (org). Percepção ambiental : a experiência brasileira. São Carlos: EdUfscar, 1996. 265 p.

DELORS, J. Educação: um tesouro a descobrir. 3. ed. São Paulo: Cortez, 1999. 225p.

DEMO, P. Conhecer \& aprender : sabedoria dos limites e desafios. Porto Alegre: Artmed, 2000. 152 p. (Série Biblioteca Artmed: fundamentos da educação).

EMPRESA BRASILEIRA DE PESQUISA AGROPECUÁRIA. Núcleo de monitoramento ambiental e de recursos naturais por satélite (Campinas, SP). Mapa do uso das terras: Município de Campinas. Campinas, 1993. p. 9-10. Escala 1:100.000.

FERRARA, L. D. A. As Cidades llegíveis - Percepção Ambiental e Cidadania. In: DEL RIO, V.; OLIVEIRA, L. (org). Percepção Ambiental: a experiência brasileira. São Carlos: EdUFSCar, 1996. 265p.

FREIRE, P. Educação e mudança. Rio de Janeiro: Paz e terra, 1979. 79p. (Coleção: O mundo hoje, 36).

FREIRE, P. Uma palavra de Paulo Freire. In: VIEZZER, M.L.; OVALLES, O. (Org.). Manual latino - americano de educ-ação ambiental. São Paulo: Gaia, 1995. 269p.

FREIRE, P. Educação como prática da liberdade. Rio de Janeiro: Paz e Terra, 1996. 150p.

GONÇALVES, C.W.P. Os (des)caminhos do meio ambiente. São Paulo: Contexto, 1989. 156p. 
GONÇALVES, D.R.P. Educação ambiental e o ensino básico. In: SEMINÁRIO NACIONAL SOBRE UNIVERSIDADE E MEIO AMBIENTE, Santa Catarina, 1990. Anais. Santa Catarina: UFSC, 1990. p.04.

HAMMES, V. S. Contribuições para o planejamento agroturístico na área de proteção ambiental de Sousas e Joaquim Egídio (Campinas - SP). Campinas, 1998. 184 p. Dissertação (Mestrado) - Faculdade de Engenharia Agrícola, Universidade Estadual de Campinas.

IANNI, O. A sociedade global. São Paulo: Editora Civilização Brasileira, 1992. $92 \mathrm{p}$.

INSTITUTO DE PESQUISAS TECNOLÓGICAS. Manual de ocupação de encostas. São Paulo, 1991. 231p.

JACOBI, P. R. Problemas ambientais e qualidade de vida na cidade de São Paulo: percepções, práticas e atitude dos moradores. São Paulo: Cedec, 1994. 203p.

JACOBI, P.R. Educação para a cidadania: participação e co-reponsabilidade. Revista: Debates Sócio Ambientais, v.2, n.7, p.2,1997.

JACOBI, P.R. Educação Ambiental para cidadania. São Paulo: (Estado). Secretaria do Meio Ambiente / Coordenadoria de Educação Ambiental. 1998. Educação, meio ambiente e cidadania: reflexões e experiências. 104p.

JACOBI, P. R. Educação, ampliação da cidadania e participação. Revista Educação e Pesquisa. v. 26, p. 11-29. jul/dez, 2000.

KRASILCHIK , M. Educação ambiental na escola brasileira - passado, presente e futuro. Revista Ciência e Cultura. v. 38, p. 1958-1961, 1996. 
LAGO, A. ; PÁDUA, J.A. O que é ecologia? São Paulo:Brasiliense, 2001. 108p. (Coleção Primeiros Passos).

LAKATOS, E. Metodologia do trabalho científico. São Paulo: Atlas, 1992. 214p.

LASCH, C. O mínimo eu - sobrevivência psíquica em tempos difíceis. São Paulo: Editora Brasiliense, 1986. 285 p.

LEFF, E. Epistemologia ambiental. São Paulo: Cortez, 2001. 240p.

LERIPIO, D. L. Educação ambiental e cidadania: a abordagem de temas transversais. Florianópolis, 2000. 168p. Dissertação (Mestrado) - Programa de Pós-graduação em Engenharia de Produção, Universidade Federal de Santa Catarina.

LIBÂNEO, J.C. Democratização da escola pública : a pedagogia crítico-social dos conteúdos. São Paulo: Loyola, 1980. 149 p.

LIBÂNEO, J.C. Adeus professor, adeus professora? : novas exigências educacionais e profissão docente. 2. ed. São Paulo : Cortez, 1998.104 p.

LIBÂNEO, J.C. Didática. São Paulo: Cortez, 2000. 261p. (Coleção Magistério Segundo Grau. Série formação do professor).

LIBORIO, M.G.C. Código florestal brasileiro: um estudo sobre as relações entre sua eficácia e a valorização da paisagem florestal no sudeste paulista. Rio Claro, 1994. 350p. Tese (Doutorado) - Instituto de Geociências e Ciências Exatas, Universidade Estadual Paulista "Julio de Mesquita Filho".

LÜDKE, M.; ANDRÉ, M. D. E. A pesquisa em educação: abordagens qualitativas. São Paulo:EPU, 1986. 99p. 
MACHADO, L.M.C.P. Serra do mar paulista: um estudo de paisagem valorizada. Rio Claro, 1988. 312p. Tese (Doutorado) - Instituto de Geociências e Ciências Exatas, Universidade Estadual Paulista "Julio de Mesquita Filho".

MATTOSINHO, M. A educação para a conservação do ambiente na área de proteção ambiental da região de Sousas e Joaquim Egidio - Campinas, SP. Campinas, 2000. 315p. Dissertação (Mestrado) - Instituto de Geociências, Universidade de Campinas.

MATTOS, C. O. "Contribuição ao planejamento e gestão da área de proteção ambiental de Sousas e Joaquim Egídio, Campinas-SP". São Paulo, 1996. 225p. Dissertação (Mestrado) - Departamento de Ecologia Geral do Instituto de Biociências, Universidade de São Paulo.

MATURANA, H.; VARELA, F.G. A árvore do conhecimento - As bases biológicas do entendimento humano. São Paulo: Psy II, 1995. 296p.

MINISTÉRIO DO MEIO AMBIENTE; INSTITUTO DE ESTUDOS DA RELIGIÃO. O que o brasileiro pensa de meio ambiente e consumo sustentável. Brasília, 2001. 35p. (Pesquisa Nacional de Opinião - Relatório para divulgação).

MORIN, E. Terra-Pátria. Lisboa: Editora Instituto Piaget, 1994. 156p.

MORIN, E. Os sete saberes necessários à educação do futuro. São Paulo: Cortez, 2000. 118p.

MORIN, E. Por uma globalização plural. Folha de São Paulo. Caderno mundo, São Paulo, 31 mar. 2002. p. A17. 
NOGUEIRA NETO, P. Ação política da Secretaria especial do Meio Ambiente para a defesa do patrimônio vegetal do país. Silvicultura em São Paulo, v. 16, p.142-149. 1982. IApresentado ao Congresso Nacional sobre Essências Nativas, Campos do Jordão, 1982. - Resumo/

NOLETO, M.J. Abrindo espaços - Educação e cultura para a paz. Brasil: Unesco, 2001. 87p.

OLIVEIRA, J.B. de. Características morfológicas, analíticas, limitações e aptidão agrícola dos solos da quadrícula de Campinas. Campinas: IAC, 1980. 79p. (Circular, 109).

PATTON, M.Q. Qualitative evaluation and research methods. New York: Sage, 1990. 120p.

PEGORARO, J.L. Educação ambiental: a temática da flora, da fauna e dos ambientes naturais (expressões da biodiversidade) a partir da educação formal. Piracicaba, 1998. 203p. Dissertação (Mestrado) - Escola Superior de Agricultura "Luiz de Queiroz" - Universidade de São Paulo.

PELICIONI, A. F. A Educação Ambiental na escola - um levantamento de percepções e práticas de estudantes de primeiro grau a respeito de meio ambiente e problemas ambientais. São Paulo, 1998. 118p. Dissertação (Mestrado) Faculdade de Saúde Pública, Universidade de São Paulo.

PIRES NETO, A.G. Caracterização e subsídios para a gestão integrada de bacias hidrográficas do Município de Campinas: relatório da assessoria técnica. Campinas: PMC-SEPLAMA, 1995. 161p.

RAMOS, L.F.A. Meio ambiente e meios de comunicação. São Paulo: Annablume, 1995. 136p. 
REIGOTA, M. O que é educação ambiental. São Paulo: Brasiliense, 1994. (Coleção: Primeiros Passos). 62p.

REIGOTA, M. Por uma filosofia da educação ambiental. In: MAGALHÃES, L.E. (coord.) A Questão Ambiental. São Paulo: Terragrah, 1994. 345p.

REIGOTA, M. Desafios a EA escolar. In: CASCINO, F.; JACOBI, P.; OLIVEIRA, J.F. (org.). Educação, meio ambiente e cidadania: Reflexões e experiências. São Paulo: SMA/CEAM, 1998. 278p.

SABIA, I. R. A escola e a educação ambiental: Relatos de experiências. In: CASCINO, F.; JACOBI, P.; OLIVEIRA, J.F. (org.). Educação, meio ambiente e cidadania. Reflexões e experiências. São Paulo: SMA/CEAM, 1998. 278p.

SANTANA, I. Distritos criam ONG para preservar ambiente. Diário do Povo, Cidades. Campinas, 14 set. 2000. p.4.

SANTOS, A. P. N. Proposta de um programa de educação ambiental para alunos do ensino fundamental no jardim botânico da UNESP / Botucatu. Botucatu 1998. 127p. Dissertação (Mestrado) - Instituto de Biociências da Universidade Estadual Paulista "Julio de Mesquita Filho".

SANTOS, B.S. Pela mão de Alice: o social a político na pós-modernidade. São Paulo: Cortez, 1999. 348p.

SANTOS, B. S. Um discurso sobre as ciências. Portugal: Afrontamento, 1995. $58 \mathrm{p}$.

SANTOS, M. Território: globalização e fragmentação. São Paulo: Hucitec/Anpur, 1994. $332 \mathrm{p}$. 
SANTOS, M. Técnica, espaço, tempo: globalização e meio técnico-científico informacional. São Paulo: Hucitec, 1995. 119p.

SANTOS, M. O recomeço da história. São Paulo. Folha de São Paulo, 9 jan. 2000, p. A2.

SANTOS, J.E.; SATO, M. Contribuição da educação ambiental à esperança de Pandora. São Carlos: Rima, 2001. 624 p.

SÃO PAULO (Estado). Secretaria do Meio Ambiente. Coordenadoria de Planejamento Ambiental. Áreas de Proteção Ambiental do Estado de São Paulo - APAs: propostas de zoneamento ambiental. São Paulo, 1992. 76p. (Série Documentos).

SAVIANI, D. Escola e democracia. São Paulo: Cortez, 1982. 154p.

SAWAIA, B.B. Participação social e subjetividade. In: SORRENTINO, M. (coord.) Ambientalismo e participação na contemporaneidade. São Paulo: Educ/Fapesp, 2001. 229p.

SAWAIA, B.B. Representação e ideologia - o encontro desfetichizador. In: SPINK, M.J.P. O conhecimento no cotidiano - As representações sociais na perspectiva da psicologia social. São Paulo: Brasiliense,1994. p. 73 - 85.

SEARA FILHO, G. Educação ambiental no currículo escolar. (Debate). In: SIMPÓSIO DE EDUCAÇÃO AMBIENTAL, 2., São Paulo, 1986. Anais. Local: Museu de pesca, 1986. p. 49-52. 
SECRETARIA DO MEIO AMBIENTE DO ESTADO DE SÃO PAULO. Coordenadoria de Educação Ambiental. Educação Ambiental e desenvolvimento: documentos oficiais. São Paulo. 1994. 145p. (série documentos).

SEGURA, D.S.B. Venturas e desventuras na educação ambiental na escola pública: um estudo de experiências na Zona Leste do município de São Paulo. São Paulo, 1999. 157p. Dissertação (Mestrado) - Faculdade de Educação, Universidade de São Paulo.

SERRES, M. O contrato natural. São Paulo: Editora Nova Fronteira,1991. p.124.

SORRENTINO, M. De Tbilisi a Thessaloniki, a educação ambiental no Brasil. In: CASCINO, F. JACOBI, P.R. OLIVEIRA, J.F. (org.). Educação, meio ambiente e cidadania - Reflexões e experiências. São Paulo: SMA/SEAM, 1998. 223p.

SORRENTINO, M. Avaliação de processos participativos. In: SORRENTINO, M. (org.) Ambientalismo e participação na contemporaneidade. São Paulo: Educ/Fapesp, 2001. p. 229.

SPOSATI, A. Movimentos utópicos da contemporaneidade. In: SORRENTINO, M. (org.) Ambientalismo e participação na contemporaneidade. São Paulo: Educ/Fapesp, 2001. p.229.

TASSARA, E.T.O.; TASSARA, M.; SORRENTINO, M.; TRAJBER, R. Propostas para a instrumentalização de uma Educação Ambiental transformadora. In: COSTA, L.B.; TRAJBER, R. Avaliando a educação ambiental no Brasil. São Paulo: Editora Peirópolis - Instituto Ecoar para a cidadania, 2002. p. 29-51.

THIOLLENT, M. Metodologia da pesquisa-ação. São Paulo: Cortez, 1986. 187p. 
TRIVIÑOS, A. N. S. Introdução à pesquisa em ciências sociais: a pesquisa qualitativa em educação: o positivismo, a fenomenologia, o marxismo. São Paulo: Atlas, 1990. 175p.

TUAN, Y. F. Topofilia. Um estudo da percepção, atitudes e valores do meio ambiente. São Paulo: Difel, 1980. 152p.

TUAN, Y.F. Espaço e lugar: a perspectiva da experiência. São Paulo : Difel, 1983. $250 \mathrm{p}$.

VEJA. A morte do prefeito sinaliza que ninguém está a salvo. n.05. 30 jan. 2002. p. 72.

VIANNA, I. O. A. Planejamento participativo na escola, um desafio ao educador. São Paulo: EPU, 1986. 118p.

WEIL, S. A condição operária e outros estudos sobre a opressão. Rio de Janeiro: Paz e Terra, 1979. 356p.

WEIL, S. O enraizamento. Bauru: Edusc, 2001. 